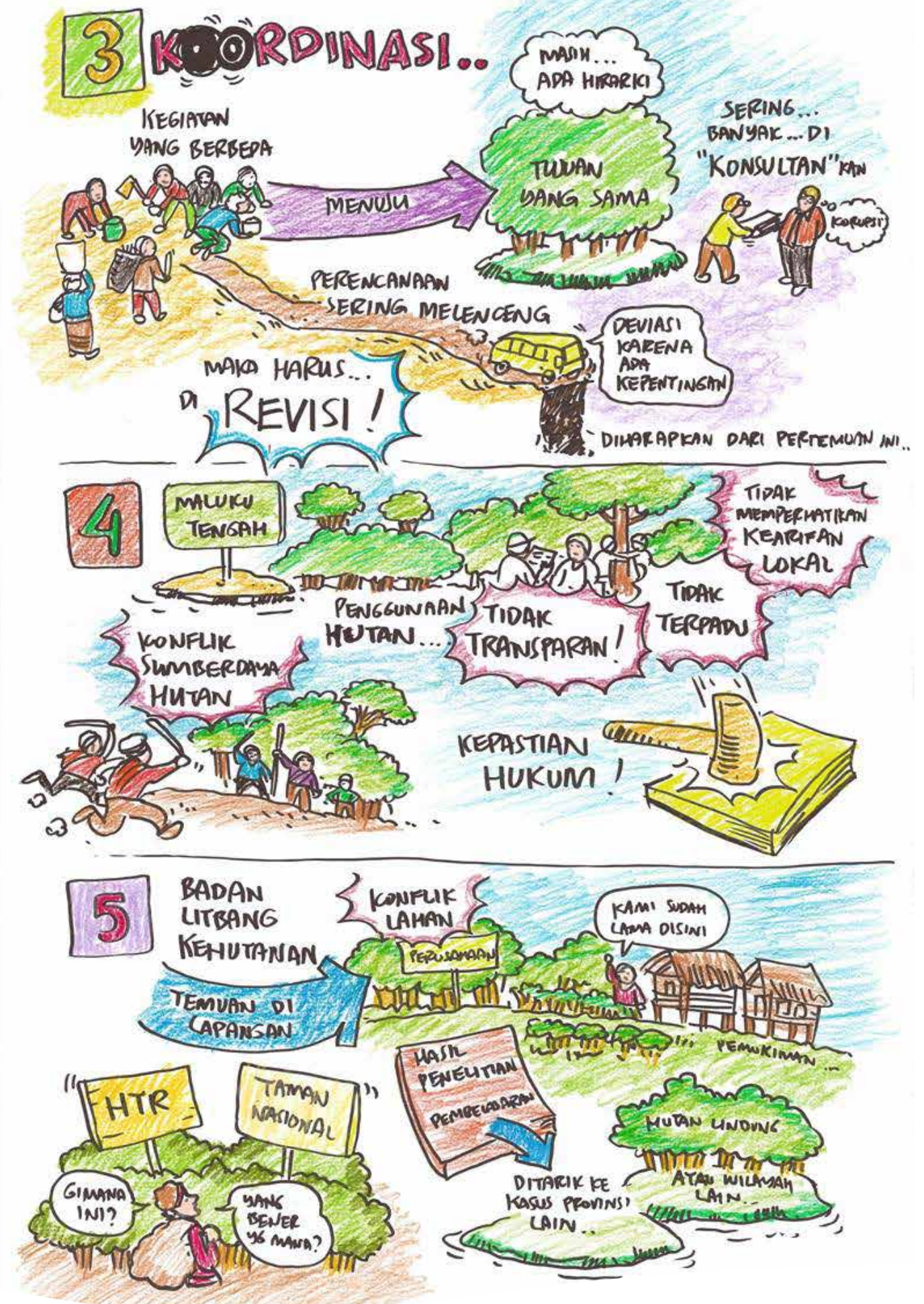

\title{
Civil society organizations' roles in land-use planning and community land-rights issues in Kapuas Hulu regency, West Kalimantan, Indonesia
}



Civil society organizations' roles in land-use planning and community land rights issues in Kapuas Hulu regency, West Kalimantan, Indonesia 
Working Paper 147

(c) 2014 Center for International Forestry Research

Content in this publication is licensed under a Creative Commons Attribution-NonCommercial-NoDerivs 3.0 Unported License http://creativecommons.org/licenses/by-nc-nd/3.0/

Chakib A. 2014. Civil society organizations' roles in land-use planning and community land rights issues in Kapuas Hulu regency, West Kalimantan, Indonesia. Working Paper 147. Bogor, Indonesia: CIFOR.

Cover photo by Colupsia material

CIFOR

Jl. CIFOR, Situ Gede

Bogor Barat 16115

Indonesia

$\mathrm{T}+62(251) 8622-622$

$\mathrm{F}+62(251) 8622-100$

E cifor@cgiar.org

\section{cifor.org}

We would like to thank all donors who supported this research through their contributions to the CGIAR Fund. For a list of Fund donors please see: https://www.cgiarfund.org/FundDonors

Any views expressed in this book are those of the authors. They do not necessarily represent the views of CIFOR, the editors, the authors' institutions, the financial sponsors or the reviewers. 


\section{Contents}

Acknowledgments

Foreword

1 Introduction 1

2 Conceptual and methodological framework $\quad 5$

2.1 Definitions and concepts $\quad 5$

2.2 Conceptual framework $\quad 8$

2.3 Methods 9

3 Research field general and specific context $\quad 13$

$\begin{array}{ll}3.1 & \text { Land-use planning in Indonesia }\end{array}$

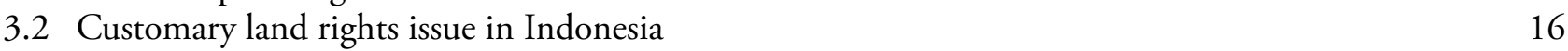

3.3 Civil society organizations and land-tenure issues in Indonesia $\quad 18$

3.4 Land-use planning in Kapuas Hulu 20

3.5 The Earth of Borneo initiative 23

3.6 The recent RTRW-K revision process in Kapuas Hulu (2010) 24

4 CSOs roles in LUP and land rights issues in Kapuas Hulu 26

4.1 CSOs profiles and objectives in Kapuas Hulu 26

4.2 Stories of CSOs action situations in Kapuas Hulu 34

4.3 CSOs action strategies comparative analysis $\quad 55$

4.4 General discussion on CSOs roles in Kapuas Hulu 66

$\begin{array}{llr}5 & \text { Conclusion } & 68\end{array}$

6 References $\quad 69$

7 Appendices $\quad 72$ 


\title{
List of tables, figures and boxes
}

\author{
Tables

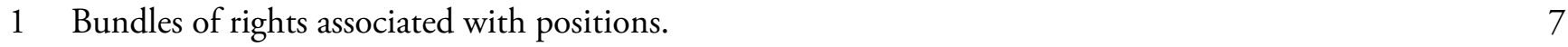 \\ 2 Details of land-use designation status changes between old and new LUP in Kapuas Hulu. 41 \\ 3 Comparison of participative process in Kapuas Hulu and civil society coalition in West Kalimantan. 56 \\ 4 CSOs participation vs civil society coalition. \\ 5 Comparison of CSOs' relations with government. 58 \\ 6 Comparison of customary land rights movement and FFI village forests approach. 61 \\ 7 Comparison of CSOs relations with government. 62 \\ 8 Respective outcomes of customary land rights and village forest approaches. 62 \\ 9 Comparison of four CSOs strategic approaches. 64 \\ 10 Soft international conservationists approach vs community-rights based hard and collective approach. 66
}

\section{Figures}

1 Deforestation in Borneo. West Kalimantan province and Kapuas Hulu Regency position in Indonesia. 2

2 Firms' cooperative strategies typology. 6

3 The democracy cube. 9

4 The spatial planning system in Indonesia. 16

5 Land-use allocation map (SK 259) in Kapuas Hulu regency. 20

6 Area per land-uses designation status. 21

7 Oil palm concessions around the Danau Sentarum National Park, Kapuas Hulu. 23

8 Limits of Heart of Borneo initiative in West Kalimantan. 24

9 Legal process of validation for regency spatial plans (RTRW-K). 25

10 Scope of CSOs involved in Kapuas Hulu since 1992.

11 Number of CSOs offices at local, regional and national levels. 28

12 Major events related to the RTRWK revision process in Kapuas Hulu (2010). 36

13 CSOs proposals for RTRW-K revision in Kapuas Hulu (2010). 38

14 CSOs participation in Kapuas Hulu spatial planning process in 2010.

15 Land-use planning changes after the RTRWK Kapuas Hulu revision process. 40

16 Civil society coalition on RTRW-P West Kalimantan. 44

17 RTRW-P process in West Kalimantan and civil society coalition actions. 45

18 "Land-rights defenders" actions in Kapuas Hulu 1996-2012. 48

19 FFI actions on village forest issues 2008-2012.

20 Hutan desa validation mechanism and FFI influence.

21 Tree of interactions on hutan desa issue in Kapuas Hulu.

22 Soft vs hard approaches and local vs policy approaches. 63

23 CSOs approaches depending on the objectives and the level of participation. 65

\section{Boxes}

1 Conservation projects in Kapuas Hulu 33

2 Customary rights defenders actions in Kapuas Hulu 34

3 The socioenvironmentalist projects in Kapuas Hulu 34 


\title{
List of abbreviations
}

\author{
AMAN \\ APL \\ ARCUS \\ BAL \\ BAPPEDA \\ BAPPENAS \\ BFL \\ BKNP \\ BKPRD \\ BKPRN \\ BRWA \\ CBFM \\ CIVICUS \\ CCP \\ CORDAID \\ CSI \\ CSO \\ DFID \\ DPRD \\ DSNP \\ EU \\ FBP \\ FFI \\ GIS \\ GIZ \\ HCVF \\ HL \\ $\mathrm{HP}$ \\ HPT \\ JKPP \\ KNPS \\ KPA \\ KUDETA \\ LBBT \\ LEI \\ LUP \\ $\mathrm{MoU}$ \\ MPR \\ NGO \\ PDD \\ POTICO \\ PPSDAK \\ PPSHK \\ PRCF \\ Aliansi Masyarakat Adat Nusantara (Indigenous People Alliance of the Archipelago) \\ Non-forest land-use areas (Areal Penggunaan Lain) \\ Arcus Foundation \\ Basic Agrarian law \\ Regional development planning agency (Badan Perencana Pembangunan Daerah) \\ National Development Planning Board (Badan Perencana Pembangunan Nasional) \\ Basic Forestry Law \\ Betung Kerihun National Park \\ Regional Spatial Planning Coordination Board (Badan Koordinasi Penataan Ruang \\ Daerah Provinsi) \\ National Spatial Planning Coordination Board (Badan Koordinasi Penataan Ruang \\ Nasional) \\ Badan Ancestral Domain Registration Agency (Badan Registrasi Wilayah Adat) \\ Community-based forest management \\ World Alliance for Citizen Participation \\ Community carbon pools \\ Catholic Organisation for Relief and Development Aid \\ Civil Society Index \\ Civil society organization \\ Department for International Development (UK) \\ Provincial parliament (Dewan perwakilan rakyat daerah) \\ Danau Sentarum National Park \\ European Union \\ First Borneo Plantation \\ Fauna and Flora International \\ Global information system \\ Gesellschaft für Internationale Zusammenarbeit (German international cooperation agency) \\ High conservation value forests \\ Protected forest [Hutan Lindung] \\ Production forest [Hutan Produksi] \\ Limited Production forest [Hutan Produksi Terbatas] \\ Network for participative mapping (Jaringan Kerja Pemetaan Partisipatif) \\ Komite Nelayan Pantai Selatan \\ Consortium for Agrarian Reform (Yayasan Konsorsium Pembaruan Agraria) \\ Coalition for the Democratization of Natural Resources (Koalisi untuk Demokratisasi \\ Sumber Daya Alam) \\ Organization of defense Banua Talino (Lembaga Bela Banua Talino) \\ Lembaga Ekolabel Indonesia \\ Land-use planning \\ Memorandum of Understanding \\ People's Consultative Assembly (Majelis Permusyawaratan Rakyat) \\ Nongovernmental organization \\ Project Design Document \\ WRI's initiative on forests and landscapes in Indonesia \\ Pemberdayaan Pengelolaan Sumber Daya Alam Kerakyatan \\ Program Pemberdayaan Sistem Hutan Kerakyatan \\ People Resources and Conservation Foundation
}


PT

PU

NRM

RePPProt

RTRW-K

RTRW-P

RTRW-N

SEBATOPA

SEKALA

SPKL

STSD

TGHK

UN

USAID

WALHI

WWF
Perseroan Terbatas

Public Work Ministry (Kementerian Pekerjaan Umum dan Perumahan Rakyat)

Natural Resources Management

Regional Physical Planning Project for Transmigration (RePPProT)

Regency spatial plan (Rencana Tata Ruang Wilayah Kabupaten)

Provincial spatial plan (Rencana Tata Ruang Wilayah Propinsi)

National spatial plan (Rencana Tata Ruang Wilayah Nasional)

Dayak local name

Serasi Kelola Alam

Farmers group

Serikat Tani Serumpun Damai

Consensus-based forest land-use planning (TGHK - Tata Guna Hutan Kesepakatan) United Nations

The United States Agency for International Development

Wahana Lingkungan Hidup Indonesia

World Wildlife Fund 


\section{Acknowledgments}

I must first thank Esther Mwangi, my supervisor at CIFOR, who made this internship possible. Her help and support have been crucial for the success of this work. I really appreciated her helpful comments and encouragement. I would also like to thank Yves Laumonier, the CoLUPSIA project director who met me in Montpellier before I joined his team in Indonesia. I am grateful to him for this amazing opportunity.

I would like also to thank Pierre-Marie Aubert, my supervisor at ENGREF-AgroParisTech. He has always been available to answer my questions and to provide me with valuable advice and comments. I would like to thank him sincerely for his latest suggestions that considerably helped me to improve this work.

My warm thanks must go to all the people who helped me to conduct my research by sharing their knowledge and experience. Thank you to Ibu Linda
Yuliani, Bapak Bayuni Shantiko and Bapak Danan. I would like to thank also Ibu Popi Astriani who took care of logistics and administrative isues. I am so grateful also to Linda and Sri, my new friends, without whom nothing would have been possible. Thank you for your patience and motivation, thank you for everything.

I am also grateful to all the people that I met in Kapuas Hulu and Pontianak. It was a wonderful personal experience. Terima kasih banyak!

Last but not least, I must thank my friends and family who supported me during these months. Thank you very much to Ariane, Thibaut, Edith and Nicolas - the Bogor 'dream team'. My warm thanks go to Soufiane and Reda, my elder brother and to my parents Eliane and Zerktouni. Finally, thank you to David, Erika and Olivier for who you are. Terima kasih banyak! 


\section{Foreword}

This report was written for the COLUPSIA project (Collaborative land-use planning and sustainable institutional arrangements for strengthening land tenure, forest and community-rights in Indonesia). The COLUPSIA project is a CIFOR-CIRAD fouryear (2010-2014) project funded by the European Commission. It links different Indonesian partners such as NGOs and universities.

The overall objective of the COLUPSIA project is to avoid deforestation and environmental degradation by supporting the development of sustainable institutional arrangements promoting land policies and instruments involving local communities. Thus, it aims to promote collaborative and equitable landuse planning (LUP) and natural resources management (NRM) that include new institutional arrangements, environmental policies, land tenure security and community-rights. 


\section{Introduction}

During these last decades, the concept of civil society has become increasingly popular and civil society organizations (CSOs) have become more numerous all over the world. International organizations and donors have supported a growing CSO movement in order to promote democracy, development, good governance and sustainable natural resources management issues. A growing number of CSOs (mainly nongovernmental organizations, NGOs) have addressed human rights, land tenure and environmental issues, particularly in many developing countries.

Scholars have studied CSOs and their roles in various issues. Endless research in the political and social sciences have provided a large amount of literature on CSOs, including a significant focus on NGOs. Researchers have studied how CSOs try to influence policies on natural resources management and land-tenure issues. Other have studied field projects conducted by CSOs. Scholars have also analyzed networking and collective action among CSOs. More generally, civil society organizations' strategies and actions have been described and analyzed by social sciences scholars (Johnson and Prakash 2007).

In Southeast Asia, Indonesia was governed by an authoritarian regime for 30 years (The New Order, 1967-1998). Freedom of expression and freedom of association were not fully recognized and civil society was restricted and controlled (Hadiwinata 2003). But in the 1990s and especially after the fall of Suharto's regime in 1998, CSOs became numerous and active (Ibrahim 2006). At the national scale, large CSOs movements and networks have addressed various issues including communities land rights and environmental issues (Di Gregorio 2011). Since 1998, democracy and freedom of expression have opened a new era for CSOs all over Indonesia. Di Gregorio (2011) described the collaborative and networking strategies of CSOs engaged in influencing policymakers in environmental, agrarian and customary rights issues. A scoping study at the national scale suggests that strong and organized CSO networks advocate environmental, forests and customary rights issues.
Indonesia has the second largest tropical forest area in the world and is a major tropical timber producer and exporter (Barr 2006; FAO 2010). Private timber companies and illegal loggers have exploited Indonesian forests for a long time (Singer 2009). Some authors argue that illegal logging constitutes $50-70 \%$ out of total Indonesian timber production (Casson and Obidzinski 2002). Since the 1970s-1980s, Indonesia has also become a major oil palm producer, the second in the world after Malaysia. Areas dedicated to oil palm plantations have quickly increased during recent decades, leading to high rates of deforestation in Indonesia (Wicke et al. 2011). The government, through the delivery of thousands of concessions, has authorized both logging activities and oil palm plantations. Land-use planning (LUP) generally promoted large-scale industrial permits all over Indonesia. Despite unconscious economic development, these trends have raised sensitive environmental and social issues (Colchester et al. 2006). High rates of forest degradation and deforestation have attracted the attention of the international community, researchers and CSOs. High rates of deforestation (including peat swamps forests) have made Indonesia a major emitter of greenhouse gases. According to recent data, Indonesia is the biggest emitter of carbon from land-uses and landuse changes and one of the top five greenhouse gas-emitting countries in the world (Akiefnawati et al. 2010). At the same time, biodiversity loss has become a major issue, notably illustrated by the symbolic great ape Orangutan (man of forest). In addition to environmental issues, tenure and natural resource exploitation, policies have caused social and human rights problems (Colchester et al. 2006; Yuliani 2010). Despite some degree of recognition in theory, in practice, customary land rights in Indonesia have been largely ignored by the government (Safitri et al. 2011). Thus, while large-scale concessions have been attributed to logging and oil palm companies (invoking general interest), thousands of tenure and agrarian conflicts happened all over Indonesia between companies and communities (Winoto 2009). As in many developing countries, overlapping legal land rights and unrecognized customary land rights have led to social tensions. 
Spatial and land-use planning (LUP) in Indonesia has been centralized and dominated by the powerful Ministry of Forestry for a long time (Wollenberg et al. 2009). But in 1992, the issuance of a new law ${ }^{1}$ on spatial planning initiated changes that have been confirmed and enforced by Law 26/2007. Indeed, following the democratization and decentralization process, spatial planning became stratified in national (RTRW-N), provincial (RTRW-P) and regency (RTRW-K) plans. The regency spatial planning (RTRW-K) became the most detailed land-use planning process (Priatna et al. 2010). In principle, various laws issued with recent democratization guarantee civil society participation ${ }^{2}$ to spatialplanning decision-making processes.

Borneo and particularly its Indonesian part (Kalimantan) have been subjected to high rates of deforestation. Projections predict that Kalimantan forest cover will continue to decline significantly (Ahlenius 2007). One of the four provinces named
Kalimantan follows these trends. West Kalimantan province forests have been logged and oil palm plantations expansion has lead to severe deforestation. Several land-conflicts between communities and companies have been documented. Dayak ${ }^{3}$ peoples' resistance to oil palm expansion have been studied in West Kalimantan (Potter 2005).

Kapuas Hulu regency, in the eastern part of West Kalimantan, is highly forested. In contrast to other provinces in West Kalimantan (e.g. Sintang and Sambas), Kapuas Hulu seems to have been saved from deforestation. According to data on vegetation cover, forests occupy more about $75 \%$ of the Kapuas Hulu area (COLUPSIA project data 2012). The floodplain is mainly covered by seasonal lakes, freshwater swamp forests and peat swamp forests while the upper areas are covered with dipterocarp forests, submountain and mountain forests (Clerc 2010). Both these forests and wetland areas play an important role in Kapuas River hydrology ${ }^{4}$.
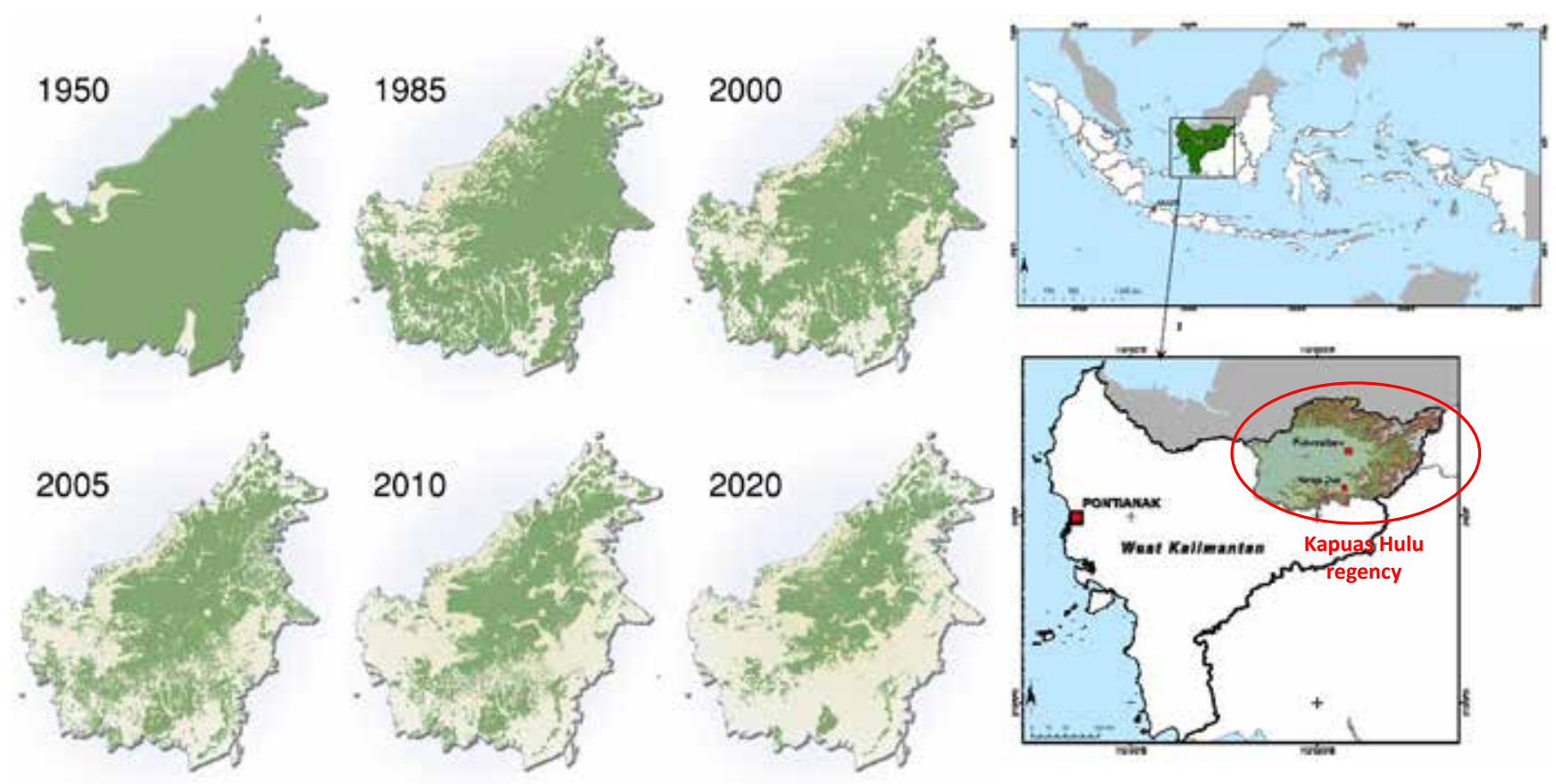

Figure 1. Left side: Deforestation in Borneo: steady diminishment of the forest cover from 1950-2005 and projected until 2020 (Ahlenius 2007). Right side: West Kalimantan province and Kapuas Hulu regency position in Indonesia (Map compiled by Agus Salim, CIFOR GIS unit).

\footnotetext{
1 UU 24/1992

2 National regulation on civil society participation in planning processes (PP68/2010).
}

3 'Dayak' is the generic term given to indigenous groups in Kalimantan, Indonesian Borneo.

4 Kapuas is the Indonesia's longest river; its floodplain constitutes the largest Wetlands in Southeast Asia 
Environmental issues in Kapuas Hulu are important. The regency has two national parks: Danau Sentarum National Park (DSNP) and Betung Kerihun National Park (BKNP) ${ }^{5}$ which occupy about $30 \%$ of the total area (BAPPEDA 2011).

But common to many places in Indonesia, forests in Kapuas Hulu have been logged by large companies and small-scale illegal loggers. Since the 1980s and up to now, large-scale logging concessions have been issued by the government. Illegal logging activities were widespread in the 2000s (Eilenberg 2012). Compared to the West Kalimantan average, very few areas of oil palm plantations exist in Kapuas Hulu. In 2012, spatial analysis shows that only 44,166 ha $(1.14 \%)$ of the Kapuas Hulu area have been converted into oil palm plantations (COLUPSIA project data, 2012). But this low number does not include planned land clearing and plantations. Indeed, since 2006, 24 location permits (izin lokasi) ${ }^{6}$ covering 406,589 ha (around 13\% of the total Kapuas Hulu area) have been issued by the local government (Kapuas Hulu Forestry and Plantation Agency 2012, see Appendix 1). Among these concessions, many have been issued in forested areas and even in close proximity to DSNP buffer zone. Therefore, operational oil palm expansion is still limited in Kapuas Hulu but planned plantations would potentially increase oil palm areas nine-fold in the future. Impacts on environment and social conditions seem inevitable.

In this context, LUP is important. By defining the rules in terms of land-use and spatial repartition, the Kapuas Hulu spatial plan (RTRW-K) influences land-uses, land-use changes and natural resource management. The first land-use planning map for Kapuas Hulu was issued in 1985. It was replaced in 2000 by the land-use designation map SK 259. This map classified $56.6 \%$ of the Kapuas Hulu area as under protected status, $24.5 \%$ under different production forest status and $18.8 \%$ as non-forest land-use areas (APL) (BAPPEDA 2011). All the oil palm location permits in Kapuas Hulu have been issued on these $18.8 \%$ of APL.

Recently, the ongoing democratization and decentralization processes in Indonesia has

\footnotetext{
5 BKNP and DSNP were established in 1995 and 1999, respectively.

6 Location permits (izin lokasi) are not an authorization for operational activities but represent the first step of oil palm concession issuance. For more information, see Appendix 2.
}

influenced the development of new spatial planning laws. A new law on spatial planning was issued in 2007 (UU 26/2007). It states the roles of regencies' governments in designing new spatial plans under newly fixed rules (Hudalah and Woltjer 2007). Under the new law, local planning agencies (BAPPEDA) coordinate spatial plans revisions processes. Law 26/2007 theoretically recognizes the public participation right to all stages of the spatial planning process including decision-making process. Finally, an additional governmental regulation (PP 26/2008) states that all existing spatial plans in Indonesia (RTRWN, RTRW-P and RTRWK) must be revised within two years (Priatna et al. 2010). That is why, in 2010, Kapuas Hulu regency government conducted its spatial planning revision process.

Thus, while CSOs at the national level advocate several issues related to LUP (i.e. environment, forests policies, oil palm expansion and customary land rights), it is interesting to question the role of CSOs at a lower scale. Kapuas Hulu presents an interesting context for studying LUP and land rights issues. Indeed, sensitive environmental and social issues coexist with large-scale industrial concession projects. While oil palm location permits already cover $70 \%$ of the APL in Kapuas Hulu, the land-use planning context is an interesting area to study. Moreover, customary land rights issue seems to be key because concessions are attributed in populated areas.

At the same time, recent democratization in Indonesia has opened a new space for $\mathrm{CSO}$ to influence policies. In general, civil society participation is viewed by governance scholars as an important condition for good governance (Roy 2008). A report by the FAO on good governance in land tenure argues that "Laws and plans should be prepared in an inclusive and transparent process to encourage and enable fully participatory mechanisms whereby all stakeholders have the opportunity to make inputs into the planning process and whereby these inputs are considered" (FAO 2007). Therefore, studying CSO participation or non-participation in the land-use planning process in Kapuas Hulu emerges as a particularly interesting research topic. Moreover, while CSOs are organizations following various objectives with different strategic choices, it is interesting to study how CSOs influence land-use planning and customary land rights issues. Thus, the following research question has guided my work: 
What roles do civil society organizations (CSOs) play in land-use planning and community land rights issues in Kapuas Hulu regency?

1. Which CSOs have tried to influence LUP and community land rights issues in Kapuas Hulu? What have been their objectives, priorities and how have they been organized to achieve their goals?

2. What strategies and what kind of activities do CSOs use to influence LUP and community land rights in Kapuas Hulu? How do they collaborate (or not) together and how do they interact with government?

This report is organized in order to answer the overall research question above. The first section provides a conceptual framework with useful definitions and concepts to understand my research approach. Then, I detail my methodological choices and the material collected during the study. The second section of this report is a general background to land-use planning and land rights issues in Indonesia. It is completed by a useful presentation of CSOs' general evolution at the national scale. Finally, the specific land-use planning context of Kapuas Hulu is outlined in order to enlighten the reader on the ongoing trends and issues in the studied regency. The third and last part of this report presents an in-depth analysis of CSOs' roles in LUP and land rights issues in Kapuas Hulu regency. A number of specific CSO action situations are specifically detailed and compared. Finally, the overall role of CSOs in Kapuas Hulu is discussed on the basis of analyzed data. 


\section{Conceptual and methodological framework}

This section provides useful definitions and a conceptual framework that guide the research. Furthermore, the methods used to collect data and to material collected are also presented.

\subsection{Definitions and concepts}

\section{Civil society}

The simplest way to define civil society is as a "third sector" separated from "the State" and "the market" (Corry 2010). Many authors complete the definition by describing civil society as a distinct arena "outside of the family, the State and the market" (Centre for Civil Society 2009). But others denounce an overly simplistic definition and criticize the fact that "Contemporary thinking gives us a picture of a global civil society that seems to be supremely uncontaminated by either the power of states or that of markets" (Chandhoke 2002). Indeed, civil society generally refers to a far more complex reality. For instance, civil society may be closely related to the State and even involved in the political area. Civil society is also often defined as an arena of collective action around shared common interests, purposes and values. It is generally represented in a wide range of spaces by various actors and institutional forms that are more or less formal, independent and powerful (Centre for Civil Society 2009).

Defining civil society is an endless topic of debate among scholars. The term civil society can be understood and analyzed in different ways depending on the historical, cultural, ideological and political contexts (Corry 2010). An author from the Centre for Civil Society clearly expresses the difficulty of defining the term civil society: "As an analytic, conceptual term, civil society is very abstract, even somewhat vague, and certainly highly complex, seemingly resistant to any precise measurement" (Anheier n.d.). However, we do not pretend in this report to give a complete analyze of what is civil society and what are the debates on the concept. Therefore, we have chosen to quote below the World Bank definition of civil society based on an abundant literature and research on civil society:

\begin{abstract}
The term civil society to refer to the wide array of nongovernmental and not-for-profit organizations that have a presence in public life, expressing the interests and values of their members or other, based on ethical, cultural, political, scientific, religious or philanthropic considerations. Civil Society Organizations (CSOs) therefore refer to a wide of array of organizations: community groups, nongovernmental organizations (NGOs), labor unions, indigenous groups, chariTable organizations, faith-based organizations, professional associations, and foundations.
\end{abstract}

World Bank (2010)

Civil society has been idealized by international organizations and donors on a worldwide scale. The United Nations (UN), the World Bank and the European Union (EU) have all launched programs to enforce and empower civil societies in developing countries. CIVICUS, a world alliance for citizen participation has developed the civil society index (CSI) to assess the state of civil society in countries around the world. In fact, the CSI aims to "enhance the strength and sustainability of civil society and strengthen civil society's contribution to positive social change" (CIVISCUS n.d.). However, in contrast to an idyllic vision of civil society, many authors point out for instance "the paradox of civil society" (Foley and Edwards 1996) or "the limits of global civil society" (Chandokhe 2002). Other scholars discuss the civil society concept and its usefulness in developing countries (Lewis 2002).

\subsubsection{Organizations and cooperative strategies}

Organizations are formal and informal organized groups of people with a particular purpose.

Organizations can be defined through objectives and means and/or through principles and functions (Foudriat 2007).

- Organizations generally follow general and particular objectives. These objectives can change over time; some objectives can be abandoned and others can be created. 
- Organizations have limited resources (human, technical, material, financial, etc.) to reach their objectives.

Organizations follow three principles: differentiation, coordination and adaptation to the environment (Foudriat 2007).

- The differentiation principle assumes that actors in an organization have various roles, skills and duties.

- The coordination principle assumes that actions of these actors must be coordinated to guarantee the coherence of the organization.

- The principle of adaptation to the environment assumes that organizations must adapt themselves and their actions to external factors and various other actors.

Organizations have been well studied by scholars. The sociology of organizations provides many theories and a large amount of knowledge on organizations functioning and structures. Strategic analysis approach analyzes organizations as political systems with internal interactions between actors. Crozier (1977) argues that the actors of an organization do not always strictly follow the rules. In contrast, they often manipulate the rules and play complex roles that reshape the organization. Moreover, according to Friedberg (1993), the power and the rules are just aspects of the organization phenomenon. There are perpetual negotiations and compromises between power and rule in any form of organized collective action. In fact, organization is at the same time a condition/state and a dynamic. Thus, organizations are both social objects and social processes (Friedberg 1993). Friedberg suggests that the sociology of organization can be used to study interorganizational relations. Rather than focusing on CSOs internal interactions, I will focus here on the external interactions between CSOs and the other stakeholders.

Thus, other approaches of organizations resulted in the theories of firms. These theories analyze internal aspects of firms and their external strategies in a context of competition. Actually, firms are for-profit organizations that make strategic choices to reach their objectives (often economic, but not only). Scholars have studied competition among firms and the emergence of collaborative strategies (Le Roy and Yami 2007). According to Le Roy and Yami (2007), firms use four types of cooperative strategies: Alliance strategies, partnership strategies, collaborative strategies and networking strategies (Figure 2). These strategies depend on the quality (horizontal/vertical) and the quantity (dyadic/multiple) of relations between firms.

Johnson and Prakash (2007) propose a collective action perspective for studying NGOs. Furthermore,

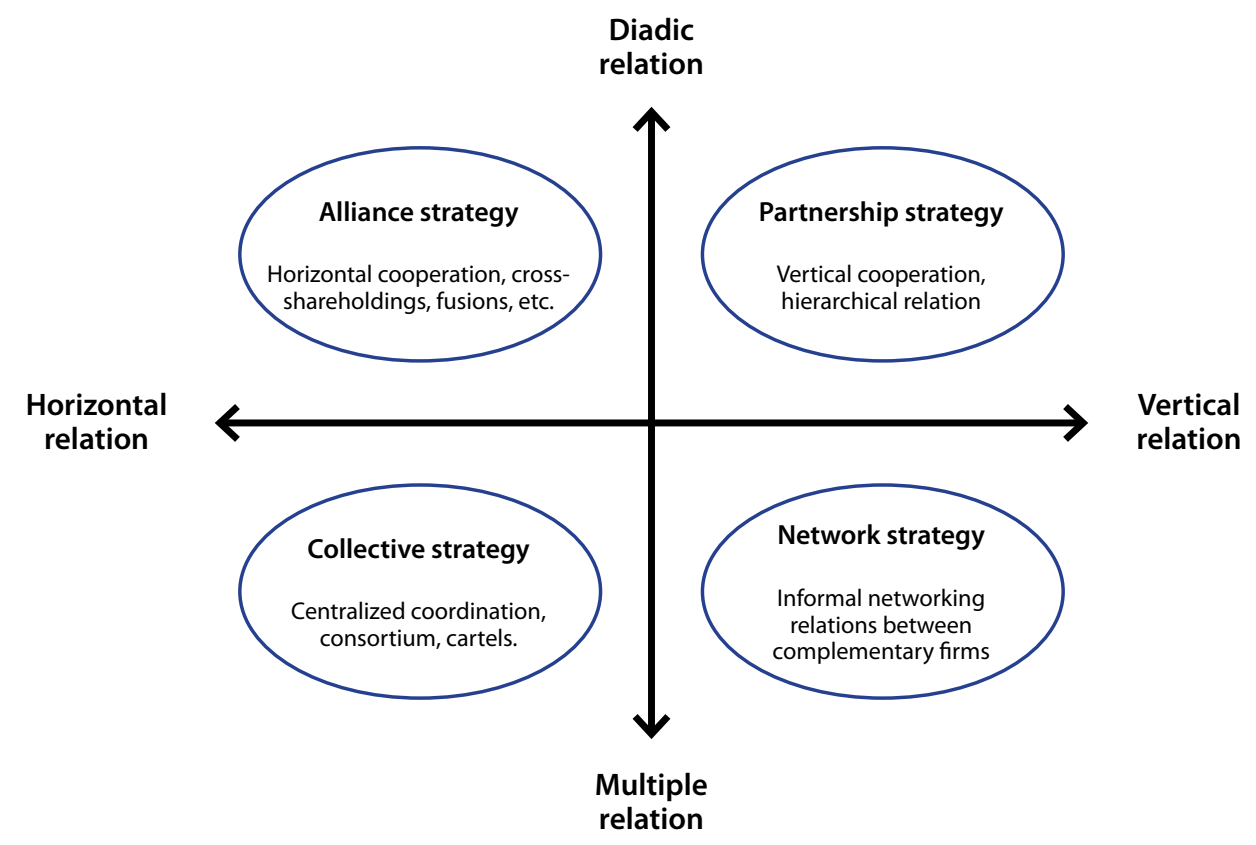

Figure 2. Firms' cooperative strategies typology.

Source: Le Roy and Yami (2007) 
the author suggests that NGOs should be considered as firms. Although NGOs are theoretically non-for profit organizations, the authors argue that they often share organizational similarities with firms. The cooperative strategy typology proposed by Le Roy and Yami (2007) may be useful in studying cooperation among NGOs. Do CSOs in Kapuas Hulu use similar cooperation strategies with firms (Figure 2)? Which ones and how?

\subsubsection{Land rights and theory of access}

Schlager and Ostrom (1992) describe two kinds of rights. The first kind, called "de jure rights" is associated with a formal and legal recognition. These rights are secured by law and administrative documents. The second one called "de facto rights" refers to not administratively and legally recognized rights. These rights are contextual and submitted to relative insecurity. Nowadays, in many developing countries, despite some theoretical recognition in law, customary rights on land are often de facto rights. It generally results in various forms of tenurerights insecurity for the communities (Peluso and Vandergeest 2001; Clerc 2010).

In terms of property rights to common-pool resources, Schlager and Ostrom (1992) define four types of rights: access, management, exclusion and alienation. Therefore, four types of users are proposed: owners, proprietors, claimants and authorized users. Every kind of user has a specific bundle of rights (Table 1). Schlager and Ostrom (1992) provide the following definitions:

Access: The right to enter a defined physical property

Withdrawal: The right to obtain the products of a resource

Management: The right to regulate internal use patterns and transform the resource by making improvements
Exclusion: The right to determine who will have access rights and how those rights may be transferred

Alienation: The right to sell or lease either or both of the above collective choices rights.

In Indonesia, communities which claim customary rights on forests usually cannot be considered as owners or proprietors because of the absence of legal recognition of their customary rights (Komarudin et al. 2009; Moeliono et al. 2009; Clerc, 2010). In contrast, the State is often the owner. It has the complete bundle of rights, including exclusion and alienation rights. But in parallel to legal systems, communities often have ancestral tenurial systems that attribute a different bundle of rights to local stakeholders. The overlapping and generally contradictory bundles of rights between formal laws and customary laws have led to many conflicts on land linked to customary rights issues in Indonesia (Winoto 2009).

Ribot and Peluso (2003) bring a significant contribution to the issue. Pointing to an often unclear distinction between "property" and "access" among scholars, they proposed a theory that makes a clear definition between the two terms. Thus, they define access as "the ability to derive benefits from things" in contrast with property which is "the right to benefit from things". Therefore, the authors associate access to "a bundle of power" rather than "a bundle of rights". Rights-based mechanisms of access are affected by various categories that illustrate different kinds of power relations: "access to technology, capital, markets, labor, knowledge, authority, identity and social relations" (Ribot and Peluso 2003). Indeed, in practice, power relations among stakeholders shape the access rights of each actor. In Indonesia, because of laws, political context and economic choices, local communities have often been partially or completely dispossessed of their access rights to land and resources by the powerful State and private companies.

Table 1. Bundles of rights associated with positions.

\begin{tabular}{lcccc}
\hline & Owner & Proprietor & Claimant & Authorized user \\
\hline Acces and withdrawal & $\times$ & $\times$ & $\times$ & $\times$ \\
Management & $\times$ & $\times$ & $\times$ & \\
Exclusion & $\times$ & $\times$ & & \\
Alienation & $\times$ & & & \\
\hline
\end{tabular}


What roles do theories of access and property rights play in CSOs in Kapuas Hulu? What are their objectives and strategies for community-rights?

\subsubsection{Land-use planning and participation theory}

Alexander (1992) defines land-use planning as "the development of regulatory, developmental and conservation strategies for land, taking into account the interactions between land; or, more broadly, the built and physical, social and cultural characteristics, and their institutions, norms and values". According to Graham (2005), land-use planning includes "general comprehensive planning or policy development to site specific or process planning."

The importance of land-use planning is underlined by the FAO in these terms: "The planning of landuse, and the policies, procedures and systems that control and monitor the use of land, are critical determinants of the legal use, and hence value, of land" (FAO 2007). Moreover, FAO describes some of the main approaches that contribute to well-governed land-use planning: proactive land administration; preparation of plans; participation; avoidance of conflicts of interest; appeals and balancing interests; monitoring of performance (FAO 2007).

While civil society participation seems desirable, the collaboration planning theory proposes an even more idealistic concept for participation in planning. According to Graham (2005): "collaborative planning is an interactive partnership among government, interest groups, major sectors of the community and the public, all identified as stakeholders that work toward consensus on three main phases of any planning issue-problem setting, direction setting and implementation." In complement, Graham (2005) argues that collaborative planning is an: "effective means of resolving environmental conflict and produces significant additional benefits such as improved stakeholders relations, skills and knowledge ... [that] agreements produced from collaborative planning are also easier to implement and less likely to generate opposition..."

Thus, many authors think that participation is valuable to improve governance and democracy. Fung (2006) provides an interesting framework to understand the range of institutional possibilities for decision-making processes vis-à-vis participation. Thus, the author says that three important questions of institutional design should be asked to understand the potential and limits of participation: "who participates? How do they communicate and make decisions? What is the connection between their conclusions and opinions, on one hand, and public policy and action on the other hand?" (Fung 2006). These questions would be asked for any decision-making process including participation. Land-use planning processes, if they are "participative" as suggested by FAO (2007), they would be analyzed through the analytical framework proposed by Fung (2006). The "democracy cube" presented in this publication provides a three-axes analytical framework for collaborative decision-making processes (Figure 3). The three axes of this "democracy cube" are: authority and power; participants and communication; and decision mode. Fung argues that participation in the decision-making process should be analyzed through these three axes.

While land-use planning needs a decision-making process, the questions are: how does the Kapuas Hulu government open itself (or not) to CSOs' participation? How are the decisions taken and what sort of authority does the government play?

\subsection{Conceptual framework}

Our research aims to study the role of civil society organizations on land-use planning and land rights issues. CSOs are the subjects of study. We are interested in their objectives and action strategies to influence both LUP issue and land rights issue. In addition, their relations with other stakeholders should be clarified and analyzed in a comparative way.

CSOs participation in the decision-making processes on LUP would be analyzed through the "democracy cube" conceptual framework (Fung 2006). Participant selection, decision modes and government power influence the roles that CSOs play in LUP in Kapuas Hulu. Thus, the theories of firms on collective strategies would be an interesting framework to analyze potential collective action strategies amongst CSOs. What links exist between the "democracy cube" outcomes and collective strategies choices? The pattern of participants' selection methods used and variable rights for CSOs to influence decisions would probably lead to different collective strategies. 

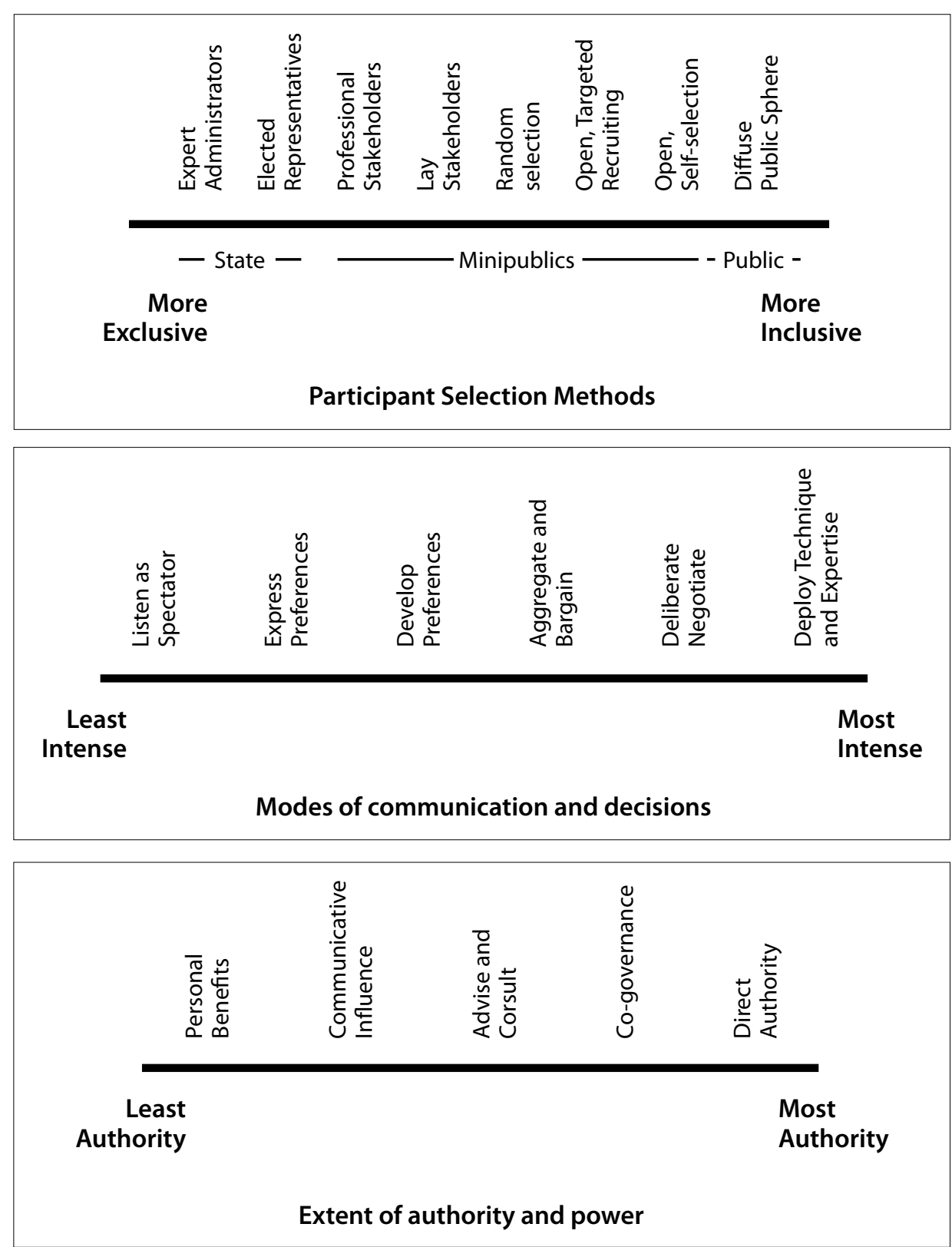

Figure 3. The democracy cube.

Source: Fung (2006)

Our research aims to link CSOs objectives and resources, decision-making processes participation rules and collective strategic choices. Our conceptual framework is made up of the sociology of organizations, the theories of firms and the democracy cube theory.

In addition, our approach is based on property rights theory (Schlager and Ostrom 1992) and the theory of access (Ribot and Peluso 2003). CSOs influence on community land rights should be analyzed through these two strong and complementary theories.

\subsection{Methods}

This study aims to understand and analyze the roles of CSOs on LUP and land rights issues in Kapuas Hulu. I have chosen to use a qualitative approach based on a literature review, semi-structured interviews, open discussions and secondary data analysis. Data on the land-use planning process in Kapuas Hulu, community land rights issues and CSOs involved in the regency were searched. Then, data on the specific relations between CSOs and between CSOs and government were collected. 


\subsubsection{Semi-structured interviews}

In order to collect qualitative data, I chose to carry out semi-structured interviews with CSOs staff (directors or managers), local government civil servants and a few other key informants. Two different interview guides were designed and used for this purpose (see Appendices 3 and 4). By interviewing CSOs, government officers and few key informants, I expected to be able to crosscheck information and avoid being influenced or manipulated by a one-sided opinion.

With CSOs, the interview guide was structured with four parts:

- general data on the CSO

- general activities in Kapuas Hulu and specific activities related to LUP and community land rights

- relations with the other stakeholders (including other CSOs and government)

- opinions on LUP and participation to the LUP process in Kapuas Hulu.

With government, the interview guide was structured with four parts:

- basic information on the respondent and his institution

- opinion on LUP in Kapuas Hulu

- opinion on CSOs actions and relations with CSOs in Kapuas Hulu

- the LUP process in Kapuas Hulu

In total, 64 semi-structured interviews were conducted. Forty semi-structured interviews (lasting 1-3 hours each) were conducted with various CSO representatives in May and June 2012. Sixteen interviews were conducted with local government civil servants. Six interviews were carryied out with some communities' representatives and two with the German cooperation agency staff. Most of the interviews were recorded (58 out of 64) and written notes were systematically taken during the discussions. Initially, there was no specific sampling method used. Starting with few names of the CSOs working in Kapuas Hulu, collected thanks to key informants, I used a snowball sample method to find more people to interview. Basically, interviewees were asked to identify other organizations and institutions that had played a role in LUP and land rights issues. A list of all interviews is given in Appendix 5.

Generally, I tried to conduct the semi-structured interviews in a flexible way in order to give the respondents the freedom to discuss various topics. Indeed, the question sequence of the semi-structured guide was often not strictly respected as people talked about many things. It was difficult to collect systematic data this way but the method often permitted the discovery of new things and a better understanding of some situations.

Most of the interviews were conducted with an English-Indonesian translator. I asked my questions sometimes in English (immediately translated into Indonesian) and sometimes directly in Indonesian. The responses were systematically translated from Indonesian into English. Finally, with a few people, I conducted interviews in English or in Indonesian without a translator.

In a country that was under an authoritarian and repressive government for 30 years, it may be difficult to form a trusting relationship with actors who are involved in sensitive issues. In order to get a good understanding of the trends, issues and relationship patterns, various sensitive topics including relations between government and CSOs or relations among CSOs had to be studied. Thus, I guaranteed anonymity to all informants and interviewees in order to give them confidence in the process and protect them from potential negative consequences. This choice also refers to my research position vis-à-vis the field that I study. Indeed, doing research and publishing a document on this topic could influence the situation and relations between stakeholders in the field. I tried to maintain an impartial position and avoid personal comments on the situation. During my interviews and various discussions, I always explained to people the objective of the research. This was difficult to convey to some activists that did not understand what the practical outcomes of my work would be. Indeed, among CSOs activists, some are critical of researchers that take data in the field, analyze them in air-conditioned offices and publish in English in international journals. They criticize the absence of outcomes in the field after long research studies. Thus, I decided to use this report as a source of information for future CoLUPSIA project activities in Kapuas Hulu. Because none of the respondents asked for their organization to be anonymous, I provide the real names of CSOs in order to make this work useful for potential future collaborations between the CoLUPSIA project and CSOs. But at the same time, when the criticisms formulated would negatively impact relations between a specific 
$\mathrm{CSO}$ and government or other CSOs, I have chosen to keep the name and organization anonymous for ethical reasons.

\subsubsection{Open discussions and workshops}

During my 2-month stay in the field, I was often involved in open discussions with CSO members, civil servants and local people. These discussions were an important source of information because people usually spoke more freely in these contexts. Indeed, in order to get a general picture of the context and to understand specific issues better, open discussions were the best way to complete semi-structured interviews. Sometimes, people did not have enough time to conduct a complete interview or the situation was not suitable for a semistructured interview. Therefore, much of the data were obtained through various open discussions. For instance, open discussions were used to cross-check information given earlier in "formal" semi-structured interview contexts. These informal discussions were not recorded. I took notes during the discussion or summed up the main idea in notebooks afterwards.

I also attended four workshops organized by some NGOs and the forestry agency. During the workshops, I only listened to the lecturer and discussions among stakeholders. I stayed in the background and did not intervene during the discussions among stakeholders. These workshops helped me to understand NGOs objectives and projects and to observe their relations with government and communities. This was also a place to meet key informants and CSOs activists. As often as possible, I took written notes. The four workshops were:

- Seminar on community mapping (organized by Lanting Borneo and the Samdhana Institute on 25-26 May 2012 in Putussibau)

- Workshop for community mapping process (organized by Jaringan Kerja Pemetaan

Partisipatif, JKPP, and Lanting Borneo on 29-30 May 2012 in Benua Martinus)

- Workshop on community-based forest management - village forest mechanism (organized by the Kapuas Hulu Forestry Agency, Fauna and Flora International, FFI, and GIZ in Putussibau on 4-5 June 2012)

- Coordination meeting between Danau Sentarum National Park (DSNP) authorities and NGOs (organized by DSNP in Pontianak on 29-30 June 2012)

\subsubsection{Literature review and secondary data collection}

Before and after the fieldwork, I conducted a literature review. I read publications and various reports to prepare for the fieldwork and to understand and analyze the data collected in the field. In addition, various secondary data from government and CSOs were collected. These data are: reports, maps, attendant lists, websites and workshops reports, etc. Some data were also founded in local newspapers and on the Internet. In general, these data were in Indonesian. It has been difficult to exploit them properly.

\subsubsection{Data analysis}

First, semi-structured interviews were transcribed in English. Then, the texts were analyzed and classified. For each major issue or domain of analysis, I summed up the long interviews texts in tables and short summaries. Notebooks were summarized and key data was extracted. Out of the large amount of data, identifying the most interesting aspects with regard to the research question was most problematic. Data was analyzed and structured in order to answer the research question: What roles do play CSOs on LUP and land rights issues in Kapuas Hulu?

\subsubsection{Difficulties and limits of the methodology}

Because my level of Indonesian was basic, I was helped during my interviews by an Indonesian translator. She helped me to ask my questions and translated the respondents' answers into English. Although her level in English was good, she was not a professional translator and not specialized in social sciences or land-tenure issues. Sometimes, she had difficulty in understanding and/or explaining everything in detail. Some data were obviously lost and some translations were possibly wrong. I realize that translation in social sciences is a source of misunderstanding and inaccuracy.

Despite my efforts, I noticed that some interviewees people did not trust me. Some of them used digressed and stonewalled to avoid directly answering to my questions. I carefully explained my research objectives, my theoretical objectivity and guaranteed them anonymity at the beginning of each interview. But I could not force people to trust me or to talk to me about sensitive issues. In particular, people from governmental agencies were often suspicious and were careful to be politically correct. They maintained very formal relations and avoided sensitive political issues. 
Sometimes I had difficulties getting precise data because of the timescale of CSO actions in Kapuas Hulu. When interviewees were speaking about old projects and past activities, their memories were often incomplete and vague. Our fieldwork was conducted over a 2-month period in West Kalimantan. It has been difficult to encompass all the aspects of CSOs activities and strategies in Kapuas Hulu with the limited time available. With more time, the data collected would probably have been more detailed and precise. 


\section{Research field general and specific context}

This section provides an essential historical and general background on LUP, land rights and $\mathrm{CSO}$ action issues in Indonesia. It is necessary to understand the general context which influences CSO strategies and objectives in Kapuas Hulu.

I first present a retrospective approach of landuse planning issues and regulations in Indonesia. Decentralization and democratization are key ideas. Second, the complex and unclear customary land rights issue in Indonesia is briefly explained. In short, customary land rights are not recognized. Then, I propose a general presentation of CSO activities over time on land and natural resources issues in Indonesia. The fall of Suharto in 1998 and the democratization process gave CSOs more freedom to operate in Indonesia. Finally, the LUP context in Kapuas Hulu is outlined.

\subsection{Land-use planning in Indonesia}

\subsubsection{Historical background}

According to Wollenberg et al. (2009), landuse planning (LUP) began on a national scale in Indonesia at the beginning of the 1980s. Since this time, three major phases have characterized landuse planning in Indonesia. The most recent policy evolution occurred in 2007 with the issuance of a new law on spatial planning (UU No. 26/2007).

\section{Centralized techno-rationalist land-use planning (1967-1992)}

Fifteen years after the creation of the forest estate in 1967, which covered around three-quarters of the Indonesian territory (Barr 2006), the first initiative of land-use planning at the national scale was conducted by the powerful Ministry of Forestry (MoF). The consensus-based forest land-use planning (Tata Guna Hutan Kesepakatan, TGHK) process started in 1982. In 1984, the first provincial TGHK maps at a scale of 1:500,000 were discussed and signed by provincial forestry agencies and validated by the governors. Then, they were sent to the Ministry of Forestry and Ministry of Agriculture to be legalized (Santoso 2003). During the whole process, there were no public consultations or civil society participation. Decisions were taken by the Ministry of Forestry alone, with little coordination with other stakeholders. Thanks to favorable technical criteria, the Ministry of Forestry confirmed the classification of 144 million ha of Indonesia's territory into forest estate (kawasan hutan) (Deddy 2005). This TGHK land-use planning process divided three-quarters of the Indonesian area into five land-use categories (Santoso 2003; Singer 2009). These general categories were more or less kept by other LUP processes.

1. Protection forests: Destined for forests functions and services protection (i.e. watershed, erosion prevention)

2. Conservation forests: Destined for ecosystems and species conservation (i.e. national parks, natural reserves, etc.)

3. Limited production forests: Destined for timber production but submitted to various restrictions in order to limit logging intensity

4. Production forests: Destined for timber and/or pulp production without particular restrictions except the ones which already exist on forest laws

5. Conversion forests: Destined for conversion to agriculture, plantation crops, settlements and/or other uses.

A few years after the beginning of this process, the DFID (UK's Department for International Development) and the Indonesian government initiated a project that aimed to improve land-use planning for transmigration programs. The Regional Physical Planning Project for Transmigration ${ }^{7}$ (RePPProT) proposed TGHK maps updates and rationalization. The new TGHK maps at a scale of 1:250,000 proposed new land-use zones and included areas for reforestation (Wollenberg et al. 2009). For about 10 years, these maps became the land-use planning reference for every province across Indonesia (Santoso 2003; Wollenberg et al. 2009). The maps were used as a basic reference for forest planning with various implications for other

\footnotetext{
7 Transmigration program carried out by Indonesian government aimed at setting up new colonies in empty regions of Indonesia, the outer islands of the periphery of the archipelago such as Papua, Sulawesi and Moluccas (Durey 2011).
} 
sectors, communities' socioeconomic development and the environment (Santoso 2003). These maps were generally made to facilitate private investment at a time when Indonesia was quickly increasing the land area dedicated to oil palm plantations. Huge transmigration programs were organized displacing people from Java to other islands based on these maps. With the use of these TGHK maps as land-use planning references for Indonesia, various problems arose (Santoso 2003):

- Overlapping problems in forest-land-uses (among logging concessions or between concessions and protected areas

- Conflicts between concessions holders and local communities about customary land rights

- Conflicts about protected areas between the State and communities about customary land rights

- Conflicts about land-use among various development sectors (forestry, mining, transmigration, plantations, etc.)

- Overlapping problems between forest areas and administrative areas.

\section{Spatial planning for regional development (1992-1998)}

In 1992, new rules for spatial land-use planning called RTRW (Rencana Tata Ruang Wilayah) were put in place by Law No. 24/1992. In principle, this law was issued in order to "increase efficiency of spatial utilization, spatial quality, harmony of spatial utilization with environment, harmony in regional growth, development equalization, national unity and integrity as well as social welfare" (Santoso 2003).

Spatial planning under the new law was coordinated by the Coordinating Board for National Spatial Use Management (BKPRN) and the National Development Planning Board (BAPPENAS). The law proposed a three-level hierarchical approach to spatial planning including national, provincial and regency levels. It initiated a partial decentralization process in land-use planning in Indonesia (Wollenberg et al. 2009). Indeed, according to Law No. 24/1992, all provinces were obliged to design new spatial plans called RTRW-P. The plans had to contain spatial planning strategies and structures and guidelines for the management of various land-use categories (Santoso 2003). Newly -founded provincial development planning agencies (BAPPEDA) working under the BAPPENAS coordination and supervision were in charge of making new provincial spatial plans (RTRW-P). Regency spatial plans (RTRW-K) had to be designed in line with their corresponding RTRW-P.
With the issuance of Law No. 24/1992, spatial planning (including land-use planning) in Indonesia adopted an intersectoral approach, became partially decentralized and included public participation in theory (Wollenberg et al. 2009). The spatial plans' objectives were to coordinate and support multisectoral economic development and to improve and rationalize the government service delivery. RTRW-P/K plans aimed to provide documentation about administrative limits, characteristics about land, potential natural resources and multisectoral opportunities for development (Wollenberg et al. 2009). Provincial spatial plans (RTRW-P) were designed for a period of 15 years with possible revisions every 5 years. They were legalized through the issuance of a regional regulation (Peraturan Daerah, PERDA). In line with a growing demand for civil-society participation, the law specified that citizens had the right to be informed about the spatial plan, and to participate in the plan-making process. A specific regulation issued in 1996 (PP 69/1996) provided details on public participation rules in spatial planning.

In spatial planning, the citizen has the rights: to participate in the processes of plan-making, land cultivation process, and land cultivation control; to be informed about general spatial plans (rencana tata ruang wilayah), detailed spatial plans (rencana detail tata ruang), and detailed engineering design (rencana teknis ruang) transparently; to obtain the utility of space and its added value resulting from spatial planning; to obtain a fair compensation in the event of being affected by the implementation of development projects based on a spatial plan. PP69/1996 Art 2 (translation in Hudalah and Woltjer 2007)

Nevertheless, despite the recognition of rights to participate in the process, civil society participation in spatial planning in Indonesia was usually very weak or non-existent (Wollenberg et al. 2009). In fact, the decision-making process did not follow a participative approach but used a hierarchical, top-down approach. In fact, the law stipulated the prominent role of the national government in preparing detailed guidelines and standards for spatial planning (Hudalah and Woldjer 2007). Despite limited decentralization, Law No.24/1992 clearly confirmed a top-down approach for spatial planning in Indonesia.

Many problems occurred with the new RTRW-P/K spatial plans that were issued all over Indonesia. The Ministry of Forestry - which before this law was the 
only governmental authority in charge of land-use planning issues - often resisted the new multisectoral approach. RTRW-P/K land-use planning maps finalizations were often very contentious because of disharmony and incompatibility with TGHK maps (Wollenberg et al. 2009). Thus, in 1994, the Ministry of Forestry established a spatial study team for synchronization of TGHK and RTRW-P. They conducted a long process of discussions and negotiations with provincial agencies and coordination bodies (BKPRN, Regional Spatial Planning Coordination Board - BKPRD, BAPPENAS and BAPPEDA). The fall of Suharto's regime temporarily interrupted their synchronization initiative in 1998.

\section{Decentralization era and the regencies empowerment (1999-2006)}

The synchronization process conducted by the Ministry of Forestry led, in 1999, to new land-use designation maps for Indonesia and its provinces. These synchronized maps replaced the old TGHK maps. For instance, in West Kalimantan, the new land-use designation map, officially named SK 259, was officially issued in 2000. It became the legal landuse designation reference in the province.

After the fall of Suharto's regime, decentralization laws empowered the regencies' governments. New regulations led to an increase in the financial resources allocated to the regency agencies, including the planning agencies (BAPPEDA). While a few regencies had made spatial plans during the 1990s, a growing number of them had used spatial planning processes in the context of decentralization (Wollenberg et al. 2009). However, there was a lack of coordination between the regency spatial plans and the provincial spatial plans. Thus, many regency plans were not validated at the provincial and national level (Wollenberg et al. 2009). In fact, the spatial plans were often made by consulting companies based in Jakarta, who often did not know the local context. Generally, they conducted very few field visits. The data collection and public participation processes were very poor. Actually, it was not uncommon to find a company photocopying large parts of other regency spatial plans to make a new plan (Wollenberg et al. 2009).

In addition, the new regency spatial plans were rarely in line with what was really happening in the field. Spatial plans and land designation were often ignored or poorly respected. Indeed, following decentralization reforms, illegal logging became widespread across Indonesia. Bureaucratic elites, business interests and local indigenous communities often tried to maximize their benefits from forest and land without any consideration of legal spatial plans or other national laws and regulations (Wollenberg et al. 2006; Moeliono et al. 2009).

In order to limit illegal activities and anarchic natural resources exploitation, which followed decentralization, the central government began to pass new national laws and regulations in 2004. This recentralization process affected spatial planning through Law No. 32/2004, which required the regency land-use plans (RTRW-K) to be coordinated with the provincial and national ones. In addition, provincial governors and national ministers were allowed by Regulation 26/2008 to override decisions made by regencies on land-use (Wollenberg et al. 2009).

\subsubsection{A new legal context on spatial planning (2007)}

After the fall of Suharto's regime and the following political and institutional reform era, Law UU 24/1992 on spatial planning was considered to be no longer relevant to the new institutional context in Indonesia. A new law on spatial planning UU 26/2007 was issued in 2007 (Hudalah and Woldjer 2007). This law introduced a more relevant framework for new institutional settings, decentralized governance and new trends related to land-use and management in Indonesia. It includes new provisions that make it clearly different from the previous one and more adapted to the current context. For instance, the law better recognizes the right for civil society to participate in the spatial planning process. Moreover, a national regulation issued in 2010 enforced the legal framework for civilsociety participation in the spatial planning process (PP68/2010).

Under Law No. 26/2007, spatial planning in Indonesia is done at three levels (national, province, regency) with a top-down compatibility hierarchy (Figure 4). In practice, this means that lower-level spatial plans should respect the ones at the higher level. But the new law also clearly stipulates the right for provincial and regency governments to design their spatial planning. Each governance level (province and regency) can coordinate its own spatial plan once it respects the upper-level plan guidelines (Hudalah and Woltjer 2007). The provincial spatial 


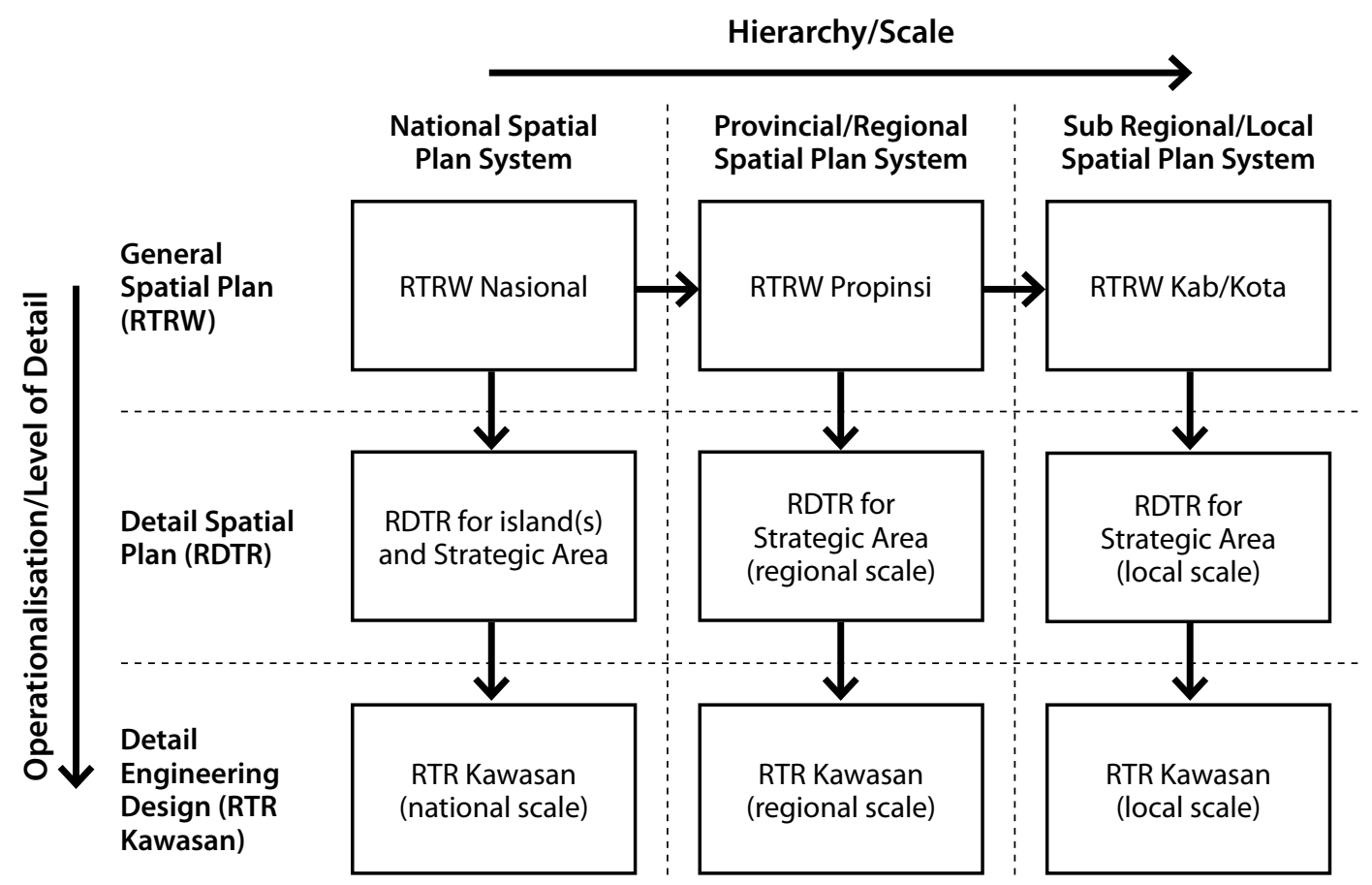

Figure 4. The spatial planning system in Indonesia.

Source: Priatna et al. (2010)

plan (RTRW-P) formulates guidance on land-use, natural resources management, settlements and infrastructures. The regency spatial plan (RTRW-K) proposes strategies to implement the choices related to land-use, natural resources, settlement and infrastructure (Priatna et al. 2010). In addition to scale levels, spatial planning in Indonesia also follows a three-level detail gradient. RTRW general spatial plans are followed by detailed spatial plans (RDTR) and detailed engineering designs (RTR Kawasan). These detailed spatial plans are used for operational implementation of general spatial plans.

\subsection{Customary land rights issue in Indonesia}

The question of customary land rights is complicated in Indonesia (USAID 2011). This issue is addressed by the 1945 Indonesian Constitution (amended in 2002) and the Basic Agrarian Law No. 5 of 1967 and the Basic Forestry Law of 1967 (revised in 1999). In addition, various regulations issued after the fall of Suharto address the issue of customary land rights. But the situation remains unclear and in practice, customary land rights are not recognized by the Government of Indonesia.

\subsubsection{Historical legal context in Indonesia}

During the Dutch colonization, despite theoretical recognition of customary land rights, the State had total control over Indonesian lands by using the concept of "general interest" to justify communities' lands confiscations and expropriations (Harwell 2000). After independence in 1945, customary land rights recognition remained unclear and generally weak. Indeed, the Indonesian Constitution of 1945 and the amended Constitution of 2001 recognize and respect the customary (adat) institutions and their customary rights (Article 18 and 28) "as long as they still exist and accord with development of the society and the principles of the Unitarian State of Republic of Indonesia, as regulated by law." (Article 18B of the Amended Indonesian Constitution, translated in Sirait, 2009). The concept of "general interest" continues to limit the recognition of customary rights. In addition, Article 33 of the constitution gives to the Indonesian State the control of earth, water and natural resources and states its guarantor a role of general interest.

The Basic Agrarian Law (BAL) of 1967 is considered to be the most important law governing land rights (USAID 2011). The roles of the State in land tenure and fundamental land rights, both for individuals 
and entities are defined by this law. The BAL is also viewed by analysts as the stronger legal basis for customary land rights protection (Harwell 2000; Sirait 2009). Indeed, Articles 3 and 5 of the BAL confirm the recognition of customary rights, including land rights. However, these customary rights are recognized as long as they are "consistent with national and State interest" (Article 3 of BAL). Again, theoretical recognition of customary land rights faces strong restrictions. The official explanation of Article 5 of the BAL clarifies the limited conditions of validity of recognition:

Nevertheless, it is not acceptable for customary law communities to invoke customary (ulayat) rights to oppose business utilization rights, since such concessions are granted in certain regions to serve the wider interest. It is also not acceptable for customary law communities to use their customary (ulayat) rights to oppose development projects, for example opposing forest clearing for generating local income or resettlement programs.

Clerc (2010)

In 1967, the issuance of the Basic Forestry Law (BFL) and the establishment of the national forest estate (around $75 \%$ of the total area of Indonesia) undermined the weak and unclear customary land rights protection contained in the BAL (Singer 2009; USAID 2011). Thus, after 1967, the BAL was no longer applied to forested areas (USAID 2011) and communities living in and around forests lost their rights to forest resources (Singer 2009). Thanks to the BFL, the Ministry of Forestry became the most powerful Ministry on land and natural resources management issues. In the 1970s and 1980s, the State used the BFL and even issued new laws to deliver numerous logging and plantations permits to private investors. Land-conflicts between communities and private companies became more numerous and the State even used the army to secure these valuable activities (Singer 2009).

The new order regime enforced the power of the central State and considerably weakened customary rights including land rights by favoring largescale private investment and organizing huge transmigration programs.

\subsubsection{New trends after the fall of Suharto}

After the fall of President Suharto in 1998, the Customary (Adat) Land Registration Policy of 1999 and Regulation No. 5/1999 issued by the National Land Agency translated Articles 3 and 5 of the BAL into operational measures. Article 1 of Regulation No. 5/1999 recognized customary rights to own land and use natural resources for the welfare of the customary community since the time immemorial (Sirait 2009). However, the regulation specified that customary rights cannot be recognized on lands where business utilization permits have been given to a private company. In fact, in 2009, only three regencies and one province had issued a regulation to recognize customary rights under the adat land registration national policy. In total, out of hundreds of customary communities in Indonesia, only four customary institutions were officially recognized and registered (Sirait 2009). Thus, this theoretical procedure for customary land rights recognition was very limited.

In the forest domain, the new forestry law issued in 1999 mentions the possibility for customary communities to get partial recognition of their management rights on ancestral forests through the classification of State forests parts in adat forests. However, the State remains the owner of these adat forests (Article 1.5) and the Ministry of Forestry must approve a management plan for each potential adat forest (Deddy 2005). In addition, the adat forest management plan must be compatible with the RTRW-K (Deddy 2005) and no customary management rights can be attributed before the issuance of a regency regulation (Article 65). Finally, it seems that this scheme for customary land rights recognition was only theoretical and has never been translated into any practical measures.

In 2001, the Decree TAP IX on Agrarian Reform and Natural Resources Management issued by the People's Consultative Assembly (MPR, Majelis Permusyawaratan Rakyat) brought new hope for customary land rights recognition. Indeed, the decree instructs the president and the house of representatives (Dewan Perwakilan Rakyat, DPR) to use a harmonization process on laws on land-use and natural resources issues (USAID 2011). The objective of the decree was to push the executive and legislative power to improve laws in terms of "equity, human rights and sustainable development" (USAID 2011). According to Di Gregorio (2011), the decree TAP IX "potentially opens the way for the recognition of community and individual rights to forest resources." But up to now (2014), the decree has not been followed by progressive regulations on customary land rights recognition. 
This unclear legal context and the State preferences for large private investments have led to many conflicts between local communities and private companies (Winoto 2009; Clerc 2010). It appears that 7491 serious conflicts cases on land (covering around 608,000 ha) happened in Indonesia in 2007 (Winoto 2009). In 2008, there was not any customary land formally owned by communities and indigenous people in Indonesia. Reserved forests for communities and indigenous groups' uses only represented 230,000 ha, or less than $0.2 \%$ of the total forested area (RRI 2009). Because customary rights have not been well-recognized, landlessness and land-conflicts have increased, and millions of people mostly in the rural area are living in tenure insecurity (Di Gregorio 2011).

\subsubsection{A new law on village forests (2008)}

In 2008, a decree gave to local communities the right to manage their forest through a hutan desa (village forest). In fact, villages (desa) are allowed to apply for hutan desa if the following two conditions are respected:

- The claimed forest is under a legal land-use status of protected forests (HL) or production forests (HPT, HP).

- The area is free of a logging concession/permit.

The area must be "clean and clear" (Interview 16) in the maps if a village wants its hutan desa. Then, the official application process can start. The village must send an application to the regency forestry agency that initiate a long process of technical and political validation through regency, provincial and national levels. The detail of the procedure will be explained later. If the village gets a village forest permit, people are allowed to manage their forest (under certain rules). Community access to the forest resources is secured by an agreement of the government. The permit can be valid for 25 to 35 years.

Hutan desa does not give full property rights to communities but only ensures forest resources access and limited management rights (defined by the law). In terms of bundle of rights presented in Schlager and Ostrom (1992), hutan desa makes the villagers "claimants". Indeed, they get access, withdrawal and (limited) management rights. Then, the village forest mechanism requires that villagers create a management group that takes the decisions related to forest management. Thus, resources access rights (Ribot and Peluso 2003) for villagers are under the control of this group. Internal power relations could occur within the community.

\subsection{Civil society organizations and land-tenure issues in Indonesia}

The first CSOs were founded in Indonesia by the Dutch at the beginning of the twentieth century. During the first years of independence, several mass organizations were founded and tried to gain political influence (Ibrahim 2006). But when the bureaucratic and authoritarian regime (The New Order) ruled by Suharto started in 1966, CSOs were placed under strict State control.

Indeed, during the Suharto regime period, democracy, freedom of expression and freedom of association were not the rule in Indonesia. The bureaucratic and authoritarian State severely restricted many collective action movements and civil society organizations (Ibrahim 2006). The Special Government Decree No. 81/1967 was only one of several mechanisms used by the regime to control Indonesian civil society. At that time, all civil society organizations had to get government approval and were systematically under State control.

However, CSOs in general and particularly NGOs, started to flourish in Indonesia at the beginning of the 1970s. At that time, a variety of NGOs were founded in order to participate in social and economic development issues (Di Gregorio 2011; Ibrahim 2006). Many of them received funds from international donors. Then, using Decree no. 81/1967 and a regulation issued in 1973 by Ministry of Home Affairs, the government controlled and monitored foreign NGOs and Indonesian organizations receiving foreign funds (Di Gregorio 2011). In the 1980s, NGOs working on environmental issues and NGOs conducting advocacy activities started to emerge. The first NGO networks related to forest and land tenure issues appeared in the 1980s, giving to their members more possibilities to improve their communication exchanges and a better situation to negotiate and collaborate with the State (Di Gregorio 2011). In reaction, the government introduced new restrictive laws in $1985 .{ }^{8}$ In reaction, to avoid these new restrictions on mass-based organizations, many NGOs changed their status from NGOs to foundations (Yayasan) (Hadiwinata 2003). In the 1990s, a growing number of NGOs carried out activities related to human rights issues and democracy. Some CSO networks became

8 Law UU 8/1985 on social mass-based organizations (ORMAS) and the presidential instruction no. 32/1985 
more radical and started to openly challenge the government. Collaborating together through various advocacy strategies, they started to link environmental, land tenure and human rights issues. These NGOs often used advocacy to support people's rights on land and natural resources, women's rights, cultural rights, gender equality and others (Ibrahim 2006). Despite an escalation in State repression against civil society, the Consortium for Agrarian Reform (Yayasan Konsorsium Pembaruan Agraria, KPA) was founded in 1994. It became a prominent CSO calling for an agrarian reform in Indonesia.

The economic crisis in Southeast Asia in 1997 together with a lack of freedom and democracy in Indonesia led to massive civil society protests. Students, supported by a range of NGOs and academics, conducted demonstrations all over the country. Finally, the civil society movement caused the fall of Suharto's regime in May 1998. It is estimated that there were around 20,000 CSOs (mainly NGOs) in Indonesia at that time (Suharko 2011 quoting SMERU).

After the fall of Suharto, with the democratization process and a more open political context, all kinds of CSOs proliferated in Indonesia (Okamoto 2001; Hadiwinata 2003; Antlov et al. 2005;

Di Gregorio 2011). Independent unions and groups, community-based groups, mass-based organizations and NGOs became more numerous. In 1999, the mass-based organization "Indigenous Peoples Alliance of the Archipelago" (AMAN) was founded in order to lobby for indigenous rights recognition, including land rights. It brought new perspectives to forest and land tenure issues (Di Gregorio 2011). The Coalition for the Democratization of Natural Resources (KUDETA) lobbied and advocated at the national scale to convince policy-makers to revise laws on natural resources management and land rights. The coalition called for the elimination of five major constraints to democratic and equitable natural resources management:

- the supremacy of national interest over customary rights which lead to property rights insecurity

- the sectoral approach to natural resources management

- the unequal legal access to natural resources

- the lack of consideration of ecological and human rights

- the lack of participation and democracy in decision-making and policy formulation.

(Moniaga (1998) quoted in Di Gregorio (2011))
In 2001, the People's Consultative Assembly ratified a decree that addresses these demands (TAP IX/2001):

The decree addresses all five demands and instructs the Parliament and the President of Indonesia to implement agrarian reforms, to revise all natural resource management laws, and to set up an effective mechanism to address existing and future conflicts over land and natural resources. In relation to forest tenure, the proposal potentially opens the way for the recognition of community and individual rights to forest resources.

Di Gregorio (2011)

Therefore, in order to formally implement the recommendation in the TAP IX decree, a group of NGOs and various networks involved in natural resources management issues founded the Working Group for Agricultural Reform and Management of Nature Resources (Di Gregorio 2011). But in 2012, most of the issues addressed by Decree TAP IX/2001 had not been fully implemented by specific regulations and laws.

In 2010, the Ministry of Home Affairs estimated that there were more than 100,000 CSOs working across Indonesia (associations, foundations and mass-based organizations) (Suharko 2011). They are involved in all the sectors of society, including development issues, democracy, education, environment, natural resources and humanrights issues. In general, the rapid growth of the civil society sector in the early 2000 s was mainly dominated by the NGO sector expansion. According to Ibrahim (2006), NGOs played a dominant role in the post-Suharto emergent civil society. NGOs importance in civil society is illustrated as follows.

If civil society were an iceberg, then NGOs would be among the more noticeable of the peaks above waterline, leaving the great bulk of community groups, informal associations, and social networks silently but not passively below.

Edwards (2004)

\subsection{Land-use planning in Kapuas Hulu}

\subsubsection{The legal land-use allocation map (SK 259/2000)}

Since the 1980s and up to 2000, the only land-use designation map available for Kapuas Hulu was the TGHK West Kalimantan map issued by the Ministry 
of Forestry in 1985. At that time, there were seven types of land status in Kapuas Hulu (COLUPSIA project). Then, after the fall of Suharto, the Ministry of Forestry issued a new land-use designation map for West Kalimantan in 2000. This legal map named SK 259 fixes the general functions and possible uses of the land for the whole Kapuas Hulu regency (Figure 5).

In Kapuas Hulu, under the SK 259, there are six land functions which include protected areas, various types of production forests and non-forested areas (Figure 5). Together, BKNP and DSNP cover more than $30 \%$ of Kapuas Hulu Regency area. In total, by summing protected forests and national parks, the protected areas cover more than 1.75 million ha and $56.6 \%$ of the Kapuas Hulu territory (Figure 6). Most of these protected areas are located in the northern and eastern parts of Kapuas Hulu. Compared to other regencies in West Kalimantan, Kapuas Hulu has the highest of protected areas (BAPPEDA 2011). However, $43.6 \%$ of the land is available for various commercial activities including forestry, plantations, mining and agriculture. Together, the three production forests land-use categories cover almost
$25 \%$ of the territory. According to the law, legal logging concessions can only be attributed in these areas. Finally, APL cover around $18.8 \%$ of the total Kapuas Hulu area (BAPPEDA 2011). In contrast with the other areas controlled by the Ministry of Forestry, these APL lands are under the control of the local government, which can attribute industrial permits for oil palm or other plantations (Priatna et al. 2010).

\subsubsection{Logging activities in Kapuas Hulu}

During the Suharto era, an undetermined number of logging concessions were attributed in Kapuas Hulu by the Ministry of Forestry to both private and State companies. Thus, large areas have been logged legally and illegally in Kapuas Hulu at least since the 1970s-1980s and probably before then. In a highly forested regency such Kapuas Hulu, logging activities have been conducted under various forms and intensity up to present.

After decentralization and new laws on forest concessions, several small-scale permits (HPHH) were issued in Kapuas Hulu. The head of Kapuas Hulu Regency (bupati) used its new power in

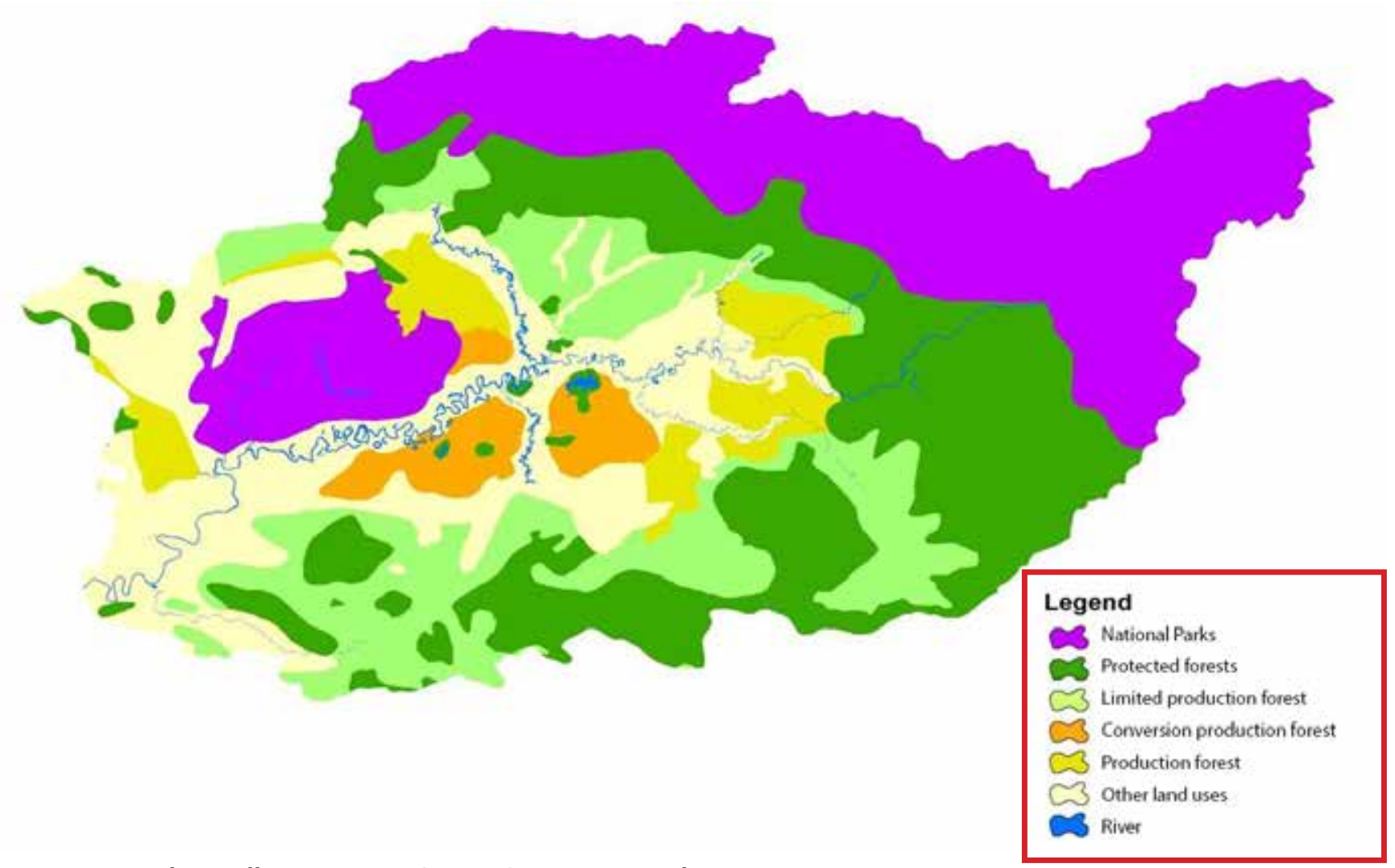

Figure 5. Land-use allocation map (SK 259) in Kapuas Hulu regency.

Source: BAPPEDA (2011) 
natural resources to maximize benefits, with little or no regard to the sustainability of these logging activities. Between 2000 and 2002, 335 HPHH were issued in Kapuas Hulu (Yasmi 2007). Many others were attributed in 2003 and 2004. In fact, logging activities with these $\mathrm{HPHH}$ were followed by a fast proliferation of illegal logging activities (Yasmi 2007).

Eilenberg provided a very interesting anthropological piece of work on illegal logging activities in the early 2000s in the borderland area with Malaysia (Eilenberg 2012). He described the systems and relationships between the stakeholders involved in illegal activities along the Kapuas Hulu northern border. Illegal logging was widespread and involved local elite brokers, communities and Malaysian timber barons. Some high-level authorities, military and politicians had probably had some interests in these illegal businesses and were then compliant with illegal loggers. In 2005, after a presidential decree on illegal logging and some police raids, illegal logging decreased in Kapuas Hulu.

In 2012, according to data from the Kapuas Hulu Regency Forestry Agency, out of 11 logging concessions (excluding HPHH) delivered in Kapuas Hulu since 1987, only four companies are still active in the area. The other companies had stopped their activities for various reasons. Some of them still hold permits but do not conduct logging activities anymore. Others lost their permits after the 2005 presidential decree to stop illegal logging. The four logging companies still active in Kapuas Hulu got their permits between 2004 and 2009 and are operating in an area of almost 150,000 ha (less than $20 \%$ of the area theoretically available for logging concessions: limited production forest, production forests and conversion production forests). Their permits are valid until 2026 to 2049 (Appendix 6).

We know that conflicts have been recorded between some communities and logging companies in Kapuas Hulu. However, it is not possible to present a complete and systematic picture of conflicts on logging issues in Kapuas Hulu. The company PT Toras Benua Sukses has numerous conflicts with the Mandalam communities. Some people denounce forest degradation and impacts on water quality. Other conflict cases will be evoked in the third section of this report.

\subsubsection{Oil palm issue in Kapuas Hulu}

In contrast to other parts of West Kalimantan, the oil palm sector came very late to Kapuas Hulu. Actually, the first plan to develop oil palm plantations in Kapuas Hulu came from the central government in 2005. At that time, the government planned to open 1.8 million ha of oil palm plantations in three Kalimantan provinces along the border with Malaysia. The project area's general plans overlapped BKNP and DSNP in Kapuas Hulu. Obviously, oil palm plantations would mean massive deforestation. The US\$ 567 million plantation project was supposed to be financed by various stakeholders

\section{Land use designation status distribution in Kapuas Hulu (SK 259/2000)}

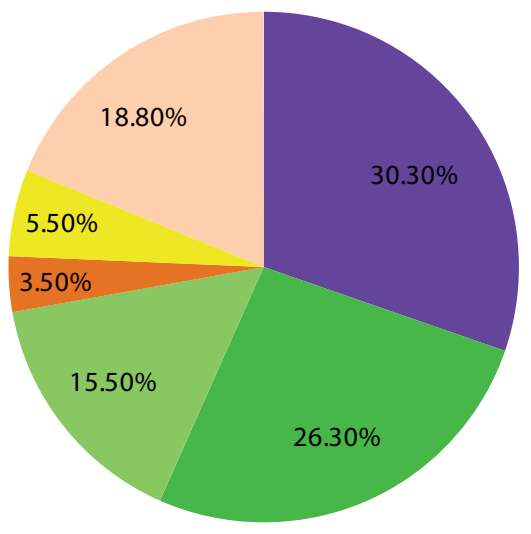

National Parks

Protected forests

Limited production forest

Conversion production forest

Production forest

Others land uses

Figure 6. Area per land-uses designation status.

Source: BAPPEDA (2010) 
including the Chinese CITIC group and the Chinese Development Bank (Wakker 2006). It appears that this transboundary oil palm mega project was never implemented. Some explanations are given in the results part of this report.

But since 2006, 23 oil palm companies have received location permits (izin lokasi) from the local government (bupati). But only a few of them have received the final authorization for operational activities (seven companies). The authorization process is still ongoing (Appendix 1). In fact, out of these 23 companies, 12 belong to the Sinar Mas group and 6 to the First Borneo Plantation (FBP) group (Appendix 1). These large internationally known firms create smaller companies (PT) with a specific Indonesian status in order to be allowed more concessions.

At the end of 2010, a total of 406,589 ha of location permits had been issued in Kapuas Hulu (Appendix 1). It represents around 13\% of the total Kapuas Hulu area and almost $70 \%$ of the area classified as APL (suitable for agriculture) in the regency land-use plan (SK 259/2000). However, in 2012, just a few have started operational activities. Most of the companies are still waiting for authorization to clear the land and plant trees. The total area effectively converted to oil palm plantations in Kapuas Hulu does not exceed 50,000 ha. It is between 42,000 ha (regency plantation agency data) and 44,166 ha (CoLUPSIA project, 2012). Thus, in 2012 , oil palm plantations cover less than $1.41 \%$ of the Kapuas Hulu area. Compared to the $56 \%$ of protected areas in Kapuas Hulu, oil palm plantations expansion seems limited. But the potential (existing permits) and the local government willingness is likely to lead to the expansion of oil palm plantations in the future.

One of the most sensitive issues about oil palm expansion is the DSNP, the largest protected wetlands in Southeast Asia (also a Ramsar site). Indeed, since 2006, the national park has been surrounded by oil palm location permits (see Figure 7). Therefore, seven oil palm concessions are situated in close proximity ${ }^{9}$ to the DSNP buffer zone. Some researchers have documented the potential negative environmental and social impacts on the Danau Sentarum area

9 Some maps edited by the CoLUPSIA project suggest that some concessions even overlap the buffer zone. But according to the official and legal data (SK 259), there is no clear overlapping of oil palm concessions with the DSNP buffer zone.
(Yuliani et al. 2010). Figure 7 also suggests that large forested areas are included in oil palm concession perimeters. These forests will obviously be cleared for plantations. Some of these areas are considered primary forests and high conservation value forests (HCVF). Finally, two concessions are situated between the two national parks, a sensitive area in terms of species migration. Thus, the potential ecological corridor between the two protected areas is threatened by oil palm expansion.

It has also been documented that some communities are opposed to oil palm concessions in their customary areas. Conflicts between communities and oil palm companies have occurred in these last years in some villages of Kapuas Hulu. Indeed, some communities reject the permit issued by the local government in what they consider as "their customary territory". A very interesting case was identified in the north of Kapuas Hulu in 2012. Ten villages unified and led by customary leaders rejected an oil palm concession issued in 2010 by the local government. They even conducted a public protest in Putussibau (the capital of Kapuas Hulu) at the end of April 2012. However, some communities accept oil palm plantations. For instance, some communities in Badau district (north of Danau Sentarum area) have signed agreements with oil palm companies.

\subsection{The Earth of Borneo initiative}

In 2007, Indonesia, Malaysia and Brunei agreed on a common conservation strategy to protect biodiversity and habitats through a conservation areas network and sustainable forest management. They signed in Bali The Heart of Borneo (HoB) Declaration, entitled "Three Countries, One Conservation Vision". In total, the heart of Borneo area covers $220,000 \mathrm{~km}^{2}$ (around $30 \%$ of the Borneo Island area). Out of this total area, $72 \%$ is located in Indonesia in 10 regencies in 3 provinces (West, East and Central Kalimantan). Kapuas Hulu is one of the regencies designated to be part of the HoB initiative in Indonesia (Figure 8). Thus, Kapuas Hulu became in 2008 a national strategic area ${ }^{10}$ (Kawasan strategis nasional, KSN). This KSN is defined as "priority space with a crucial influence on the maintenance of national security, economic growth, sociocultural preservation, natural resource utilization and functionality, and carrying capacity of the environment" (HoB 2008). This status must be taken

10 National Regulation No. 26 of 2008 


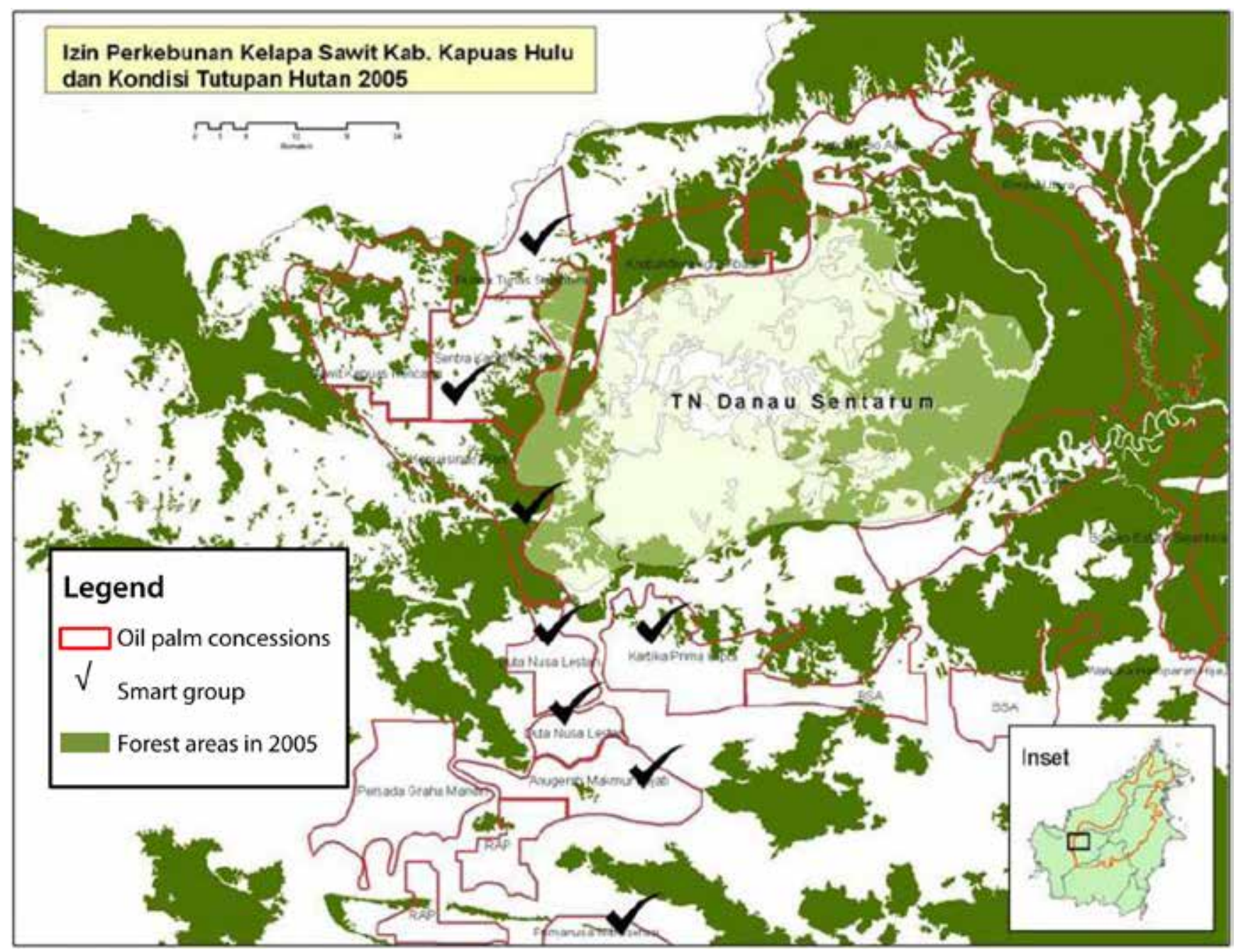

Figure 7. Oil palm concessions around the Danau Sentarum National Park, Kapuas Hulu.

Source: WWF Indonesia (2005)

into account during the regency spatial planning process. The three countries agreed on a strategic plan of action for the $\mathrm{HoB}$ initiative in 2008. It includes five pillars:

- Transboundary management

- Protected areas management

- Sustainable natural resource management

- Ecotourism development

- Capacity building

In Indonesia, the $\mathrm{HoB}$ initiative is coordinated by the government through national (pokjanas), provincial (pokjaprov) and regency working groups (pokjakab). At the regency level, the working groups are under the local government authority. In 2011, the newly founded Kapuas Hulu working group on Heart of Borneo prepared a working plan for $\mathrm{HoB}$ implementation in Kapuas Hulu. The plan includes four main tasks:
- $\quad$ spatial and land-use studies;

- studies on social, economic and cultural aspects;

- reviews of legal, institutional and advocacy;

- implementation of a socialization program with related parties of $\mathrm{HoB}$.

In addition to local government technical agencies, the Kapuas Hulu working group on Heart of Borneo involves the German cooperation agency GIZ and an international NGO (World Wildlife Fund, WWF).

\subsection{The recent $\mathrm{RTRW}-\mathrm{K}$ revision process in Kapuas Hulu (2010)}

In 2003, a spatial planning technical document (RTRW-K) was made in Kapuas Hulu under Law UU 24/1992. However, this plan was never legalized by the local parliament through a local 


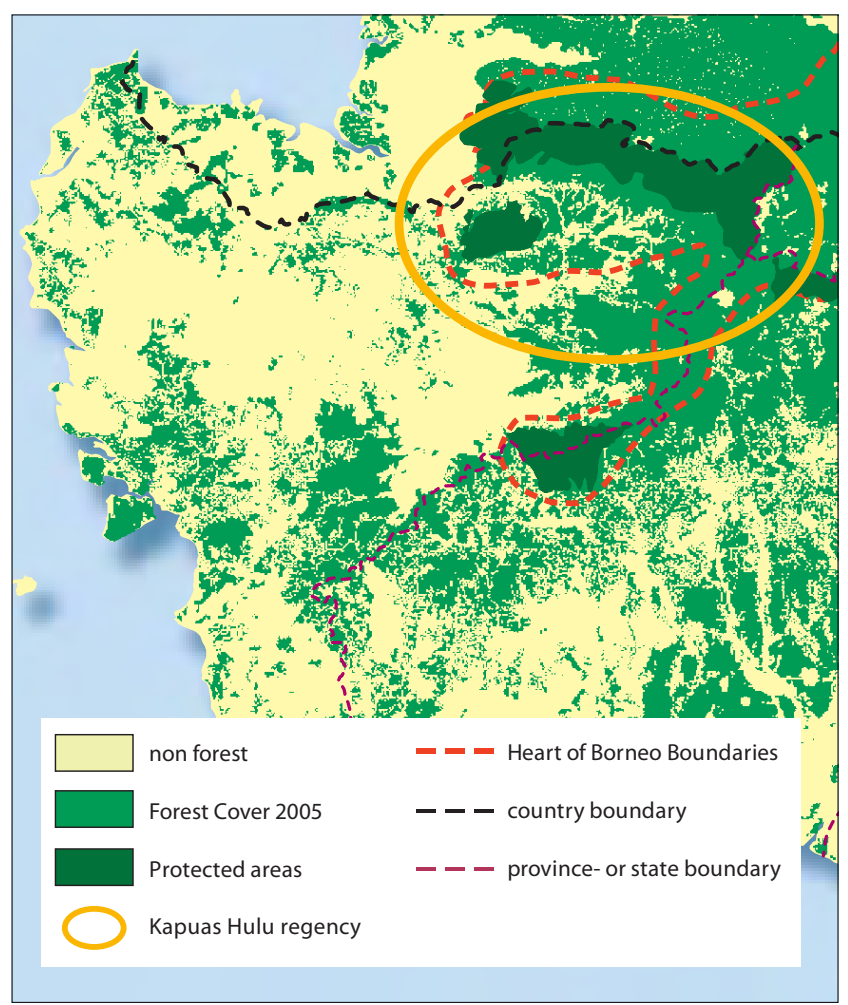

Figure 8. Limits of Heart of Borneo initiative in West Kalimantan.

Source: WWF Germany

regulation (perda). Thus, the land-use designation map remained the SK 259 map issued in 2000. The reasons why the Kapuas Hulu RTRW-K was not validated after 2003 remain unclear. Political issues and rivalries among the political elite related to local elections in this period would be one of the reasons (Interview 19, BAPPEDA).

After the issuance in 2007 of the new law on spatial planning ${ }^{11}$ (RTRW), all Indonesian spatial plans including regency plans had to be revised. Thus, in 2010, the Kapuas Hulu spatial plan (RTRW-K) revision process started under the new scheme. The following steps were conducted in 2010 (BAPPEDA 2011; Interview 19):
- preparation of the process (started in early 2010)

- data gathering

- data analysis

- society consultation

- spatial plan conception

- elaboration of the draft of regional law (finalized in December 2010)

- revision and control by central state and provinces (2011).

In order to facilitate the process, a technical working group (tim teknis) was founded in May 2010. It was coordinated by the regency coordination development agency (BAPPEDA). It aimed to support the preparation of the new regency spatial plan (RTRW-K) written by a consultancy company (PT. KOMLA Consulting Engineers) hired by the Public Work Ministry (PU). The process ended in Bogor on 26 December 2010 (Interview 19 and 41, BAPPEDA). The documents issued were:

- a 150-page technical document on regency spatial plan (RTRW-K) including a set of 17 maps.

- a draft of local regulation (raperda) about Kapuas Hulu new spatial plan for the period 2011-2031.

The process of validation of the regency spatial plan used provincial and national authorities (Figure 9). Because of the RTRW-K must be in line with higher level spatial plans, these documents have been reviewed at the provincial and national levels. In November 2011, the RTRW-K Kapuas Hulu technical document was validated by both BKPRD and the BKPRN. But while the West Kalimantan spatial plan is not yet legalized, the Kapuas Hulu DPR has not validated the new RTRW-K through a local regulation (Interview 41, BAPPEDA).

Thus, a decision-making process on LUP has recently occurred in Kapuas Hulu. Did CSOs participate? What roles did CSOs play during this process? Did they influence the outcomes? 
District government simultaneously submits draft of RTRW to the provincial government through the Regional Spatial Planning Coordination Board (BKPRD) and draft local regulations (Raperda) to enforce this to the district parliament (DPR Kabupaten).

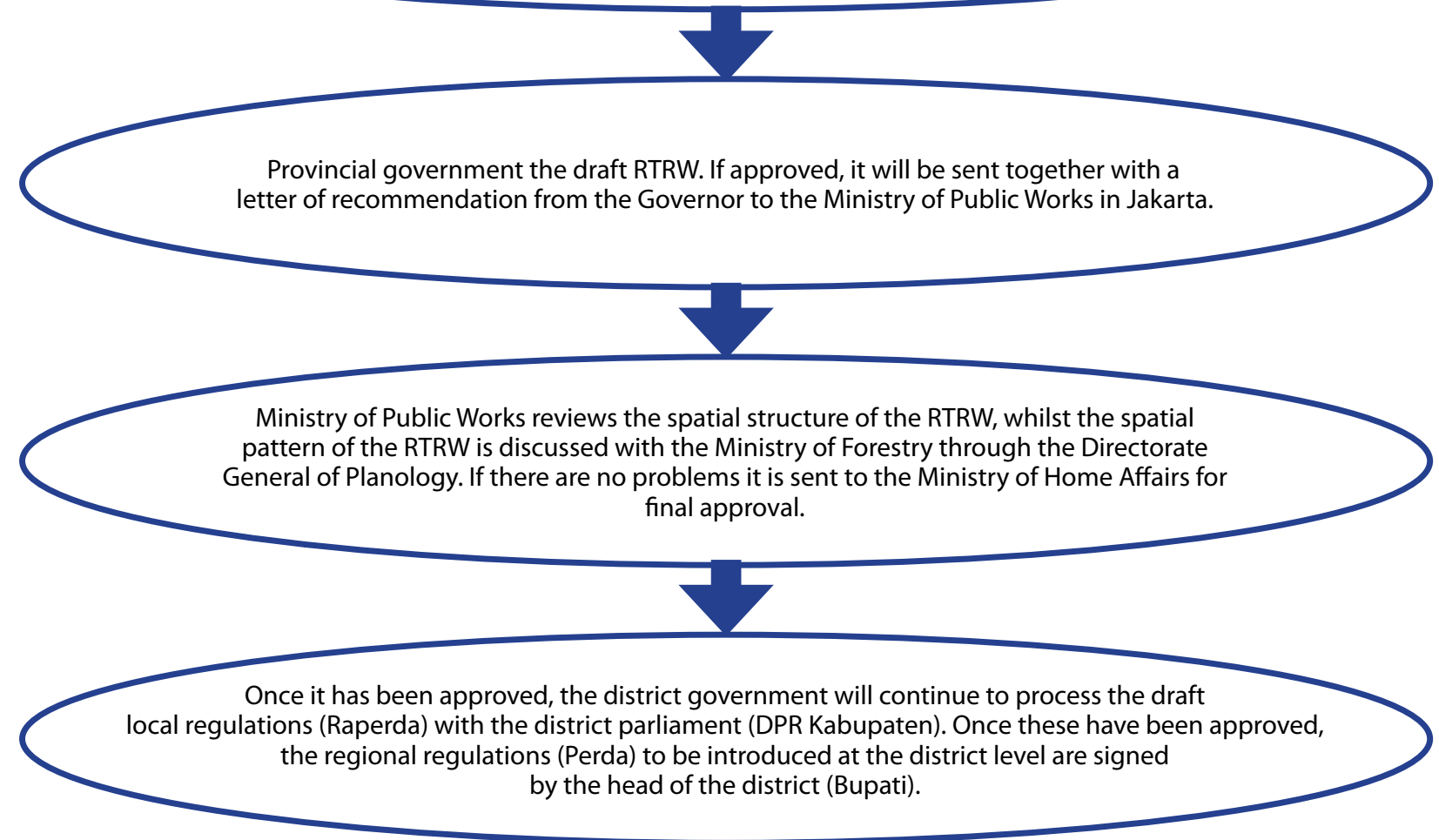

Figure 9. Legal process of validation for regency spatial plans (RTRW-K).

Source: Priatna et al. (2010) 


\section{CSOs roles in LUP and land rights issues in Kapuas Hulu}

This section is the most important part of this report. I answer the research question on CSOs, roles in the following pages. I outline in the first subsection the $\mathrm{CSO}$ profiles and their general objectives in Kapuas Hulu. Four case studies where CSOs influence LUP and customary land rights issues are presented. The results are discussed through an analytical comparison of different CSO approaches.

\subsection{CSOs profiles and objectives in Kapuas Hulu}

Since 1992, at least $23 \mathrm{CSOs}^{12}$ have worked in Kapuas Hulu regency on either land-use planning, land rights or natural resources management issues. Since the first international NGO came to the Danau Sentarum area in 1992, a wide range of CSOs have worked in Kapuas Hulu regency up to today. From the local to the international ones, from a community-rights focus to conservation preferences, from very short-term projects to longterm investments, all of these 23 CSOs have tried to play a role on one or more of these issues:

- land-use planning

- customary land rights

- natural resources management and peoples livelihoods

- biodiversity conservation.

\subsubsection{Short historic of CSOs' engagement in Kapuas Hulu}

In 2012, we recorded a total of 23 CSOs who had been engaged in land-use, land rights and/ or natural resources management issues in Kapuas Hulu over the last 20 years. Naturally, they did not start all together in the same year and their respective activities have been of variable duration and intensity. The first NGO to work in Kapuas

12 While these 23 CSOs have played roles in land and natural resources issues, there are other CSOs that have not been studied in detail because of their anecdotal role. In addition, while local informal community groups could be considered CSOs, we did not have enough time to examine them.
Hulu was Wetlands International. In 1992, it started a 3 year program in the Danau Sentarum area. In contrast, JKPP, a well-known national NGO began its first project in Kapuas Hulu almost 20 years later, in 2011. The chronology of CSOs' arrivals and departures in Kapuas Hulu is a non-linear and complex story.

Between 1992 and 1997, only four NGOs worked in Kapuas Hulu on natural resources management and land rights issues. Then, in 1998, after the fall of Suharto, more CSOs came to Kapuas Hulu to carry out various kinds of activities and projects. Globally, more NGOs worked in Kapuas Hulu after 1998 than before. But, the fall of Suharto has not resulted in a massive expansion of NGOs in Kapuas Hulu. Actually, the process seems to have been progressive.

The two first NGOs who worked in Kapuas Hulu were international conservation NGOs: WWF and Wetlands International. In 1992, Wetlands International started a 5 year program in the Danau Sentarum area (which was not a national park at that time). In 1995, WWF started to support the Indonesian government by conducting research in BKNP in order to produce a management plan for the park. A year later, in 1996, LBBT began to support the village of Sungai Utik (Embaloh Hulu district) in their conflict with a logging company. During the same year, Dian Tama received funds to work on sustainable natural resources management with the communities in Danau Sentarum area. Actually, Dian Tama was helped by Wetlands International to find a donor.

In 1998, when the Suharto regime fell, only four NGOs had worked in Kapuas Hulu: two international and two regional. They had worked in the Danau Sentarum area, in BKNP and in Sungai Utik Village on conservation, sustainable natural resources management and land rights issues.

In 1998, LBBT, which initiated the contact with Sungai Utik communities, was followed by AMAN, PPSDAK and PPSHK, three CSOs focusing on 
community-rights issues. Later, in 2000, Riak Bumi was founded by a former Dian Tama and Wetlands International staff member to continue to work with communities in the newly founded Danau Sentarum National Park (1999). In the same year, CIFOR conducted research with Dian Tama on forest fire impacts in Danau Sentarum area. In 2002, Sawit Watch carried out research on illegal logging around Danau Sentarum and WALHI started its first advocacy activities on Kapuas Hulu cases.

In 2003, 11 CSOs were working in Kapuas Hulu regency on conservation, natural resources management and land rights issues, including two international NGOs, one international research center, three national CSOs and five regional NGOs.

Then, in 2004, PRCF came to Kapuas Hulu for a biodiversity research project in Danau Sentarum. In the same year, Lembaga Ekolabel Indonesia (LEI) and Forest Watch Indonesia joined the other organizations working in Sungai Utik Village to conduct a customary forest certification process. In 2005 , Tropenbos started a 2 year research program on sustainable management and zonation in DSNP. In the same year, Yayasan Titian started to conduct investigation on illegal logging in Kapuas Hulu, including in the two national parks. In 2007, Greenpeace started research on deforestation issues around the Danau Sentarum National Park. In 2008, FFI initiated its activities in Kapuas Hulu with research projects on biodiversity and habitats.

In 2008, 18 CSOs were working in Kapuas Hulu regency on natural resources management and land rights issues, including five international NGOs, two international research centers, five national NGOs and seven regional NGOs.

In 2009, Kaban was founded and started to get involved in FFI programs in Kapuas Hulu. The World Resources Institute, in collaboration with a national consultancy company (Sekala) also started to work in Kapuas Hulu in 2009. In 2010, Lanting Borneo had its first project in Kapuas Hulu in collaboration with WWF. In 2011, Sebatopa was founded in the north of Kapuas Hulu and JKPP undertook its first activity in Kapuas Hulu with Lanting Borneo in Sungai Utik.

In 2012, 23 CSOs had activities in Kapuas Hulu. However, by 2012, only 14 of them were declared still active in the regency. ${ }^{13}$ However, not all of them are fully active in Kapuas Hulu. With the exception of: FFI, WWF, Lanting Borneo and Sebatopa, others come to Kapuas Hulu, depending on their projects and needs. Nine CSOs finished their programs or projects and now work now elsewhere in Indonesia.

For details on the CSOs involved involved in Kapuas Hulu and their activities, see Appendices 7 and 8.

\subsubsection{The prominence of NGOs}

Although CSOs in general can refer to a wide range of organizations, it seems that NGOs are the most active ones in land-use planning, land rights and natural resources issues in Kapuas Hulu regency. Indeed, out of 23 studied CSOs involved in Kapuas Hulu since 1992, 19 are NGOs, 3 are research centers $^{14}$ and 1 is a mass-based organization.

Since 1992, NGOs have been more numerous and generally more active in Kapuas Hulu than other CSOs. While research centers have had activities and projects within a certain timeframe, many NGOs have been continuously involved in various projects across Kapuas Hulu. In 2012, at least 10 NGOs conducted activities in Kapuas Hulu on various issues (conservation, natural resources management, land-use planning, land rights) but only one research center conducted a project on land-use planning.

In line with the research on CSOs around the world, this result at the regency scale in Kapuas Hulu is in line with other research that shows the importance of NGOs in the CSO landscape (Edwards 2004).

\subsubsection{From local to international organizations}

Out of 23 CSOs, two are local (regency) organizations, seven are regional (province)

organizations, six are national organizations and the other eight are international ones (Figure 10). In terms of scope of action, it seems that all kind of organizations are represented in Kapuas Hulu,

13 WWF, FFI, Greepeace, CIFOR, JKPP, Lanting Borneo, LBBT, PPSDAK, AMAN, Kaban, Titian, PRCF, Riak Bumi and SEBATOPA

14 One of the international research centers is a "think thank" called the World Resources Institute (WRI). It has conducted activities in Kapuas Hulu through collaboration with an Indonesian consulting company. We have chosen to mention the international CSO (WRI) even the real actor in the field was from a national private structure. 
from the local ones to the well-known, powerful, international one. While Sebatopa, a 1 year-old community-based NGO is working in just one district (Embaloh Hulu), the WWF claims to have won the backing of more than 5 million people from the five continents and to have invested over US\$ 1 billion in more than 12,000 initiatives all over the world since 1985. Somewhere between these two extremes is the wide range of CSOs that have been represented in Kapuas Hulu.

Two small NGOs (Sebatopa and Lanting Borneo) were founded in Kapuas Hulu by local people in 2008 and 2011, respectively. Local NGOs have been under-represented among CSOs for a long time. Regional NGOs are generally founded in Pontianak, the capital of West Kalimantan province. They have carried out activities in various regencies across West Kalimantan but usually never work at a larger scale. Seven regional NGOs have been involved in Kapuas Hulu. These NGOs, based in Pontianak, the capital of West Kalimantan are usually more represented than local ones. Even Riak Bumi, an NGO founded by a local person from Kapuas Hulu, is based in Pontianak for practical reasons. National CSOs (mainly NGOs) are usually based in Java Island, in Jakarta or Bogor. They conduct activities all over Indonesia at various scales. Some of their activities have national implications; some are focusing on a specific province and others are local. International CSOs are usually founded in Europe or in the United States. They are involved in many countries over the world. In Indonesia, they have implemented country programs that conduct activities at the local scale, including in Kapuas Hulu.

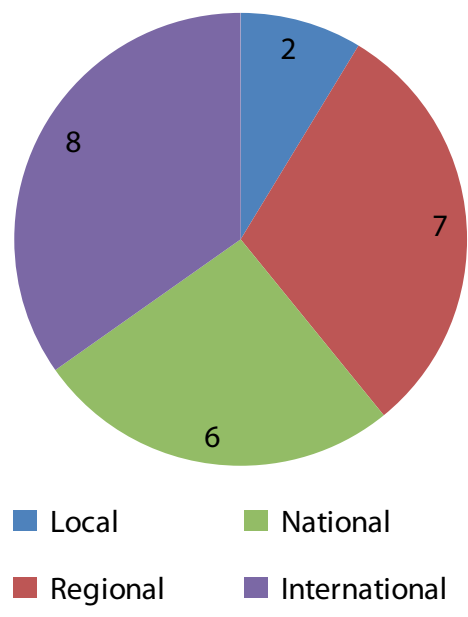

Figure 10. Scope of CSOs involved in Kapuas Hulu since 1992.

\subsubsection{Implementation strategies and intensity of involvement in Kapuas Hulu}

In general, most of the CSOs who have worked in Kapuas Hulu have not worked in the regency on a permanent basis (Figure 11). Their presence in Kapuas Hulu is usually linked to specific and temporary projects. Actually, most of the studied CSOs do not consider Kapuas Hulu as a priority. While international and national CSOs work all over Indonesia, regional NGOs work all over West Kalimantan. Collected data suggest that regional and national NGOs are never implemented at the regency scale in Kapuas Hulu. As Kapuas Hulu is a remote regency, NGO offices are far from the field. For international CSOs, the pattern is less clear. It seems that NGOs who have decided to work intensely and for a long period of time in Kapuas Hulu opened a local office in Putussibau, probably because they could affored to with of their extended budgets.

In 2012, out of the 23 studied CSOs, only four NGOs had a permanent office in Kapuas Hulu. Three of them were located in Putussibau, the regency capital of Kapuas Hulu. One is a local NGO founded by a person from Kapuas Hulu (Lanting Borneo) and the other two are international NGOs (FFI and WWF). The other NGO, Sebatopa, is a community-based NGO located in a village in the district of Embaloh Hulu. This NGO does not have an office because it is new and does not have funds. Thus, among the NGOs permanently situated in Kapuas Hulu, there are two different situations:

- The two international NGOs have a national headquarters in Jakarta and regional and/or local offices for coordination of their projects in the field. Their permanent office in Kapuas Hulu means that they have a relatively longterm strategy for projects implementation in Kapuas Hulu and a sufficient budget for that.

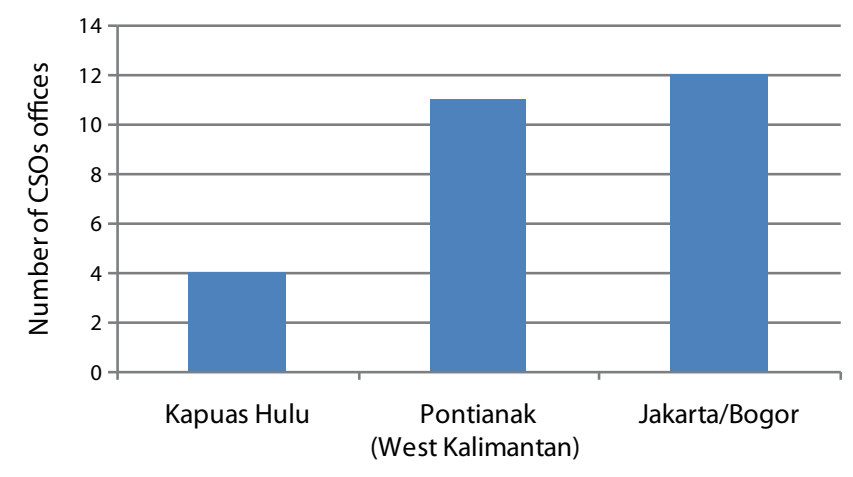

Figure 11. Number of CSOs offices at local, regional and national levels. 
Indeed, compared to other NGOs, which typically conduct a few month-long projects, WWF has been working in Kapuas Hulu since 1995 and FFI has worked in the area since 2008. They both have a higher budget than local and national NGOs.

- The two local NGOs are founded by Kapuas Hulu natives who consider the regency as a priority. While Lanting Borneo works in different areas in Kapuas Hulu, Sebatopa's scale of interest is limited to just one district. As locally founded NGOs, both have a good knowledge of the regency and the people living there.

It is important to note that an international NGO called FFI has a large office in Putussibau. They provide free accommodation for the staff of partner NGOs (Kaban, PRCF, Titian, etc.) who come to Kapuas Hulu to work in collaboration with FFI.

Among the 19 other CSOs which have not been permanently based in Kapuas Hulu, 11 NGOs have a permanent office in Pontianak, the West Kalimantan provincial capital. A majority of them (seven) are West Kalimantan regional NGOs founded in Pontianak. Two of them are provincial branches of national CSOs (AMAN-KalBar and WALHIKalBar). One of them is a small international NGO, which has a country program office in Pontianak (PRCF). One is a large international NGO (WWF) that has founded a regional office in Pontianak. For all these NGOs (except one founded by a Kapuas Hulu native: Riak Bumi), Kapuas Hulu is not a priority. They usually have activities in many regencies across West Kalimantan and have chosen to be based in the provincial capital for practical reasons. For instance, LBBT works in seven regencies in West Kalimantan and coordinates its activities from the provincial capital. Actually, most of the regionally implemented NGOs had activities in 4-9 regencies across West Kalimantan. Because Kapuas Hulu is far from Pontianak $(700 \mathrm{~km}$ and 16 hour journey by car or bus), most of them have more intense activities in less remote regencies.

It is interesting to note that the two national CSOs based in Pontianak (WALHI and AMAN) are the only national organizations to have a provincial implementation strategy in West Kalimantan. Indeed, compared to the other national CSOs, these two CSOs are well implemented and well-known across Indonesia. WALHI is implemented in 27 provinces across Indonesia and claims to have 471 members' organizations and 156 individual members (Interview 5, WALHI). AMAN has 20 provincial offices and about 1700 community members across Indonesia (17 million people) (Interview 2, AMAN). Compared to other national NGOs such as JKPP or Sawit Watch, these two CSOs have chosen active regional implementation strategies. Their regional offices are essential links with their local members for advocating local issues.

The WWF provincial office in Pontianak coordinates all WWF activities across West Kalimantan. It existed before they chose to open a branch office in Putussibau (Kapuas Hulu). This multilevel implementation strategy is possible thanks to a substantial budget provided by the WWF International network.

Out of 23 CSOs who have conducted activities in Kapuas Hulu district, 12 have a permanent representation at the national level in Java Island, either in Bogor or Jakarta. Naturally, none of the regional and local NGOs have an office outside of West Kalimantan. In contrast, all the national NGOs and almost all of the international CSOs have their Indonesian headquarters in Jakarta or Bogor in Java Island. Akin to large companies or firms, national and international CSOs seem to find several advantages to being near the country capital.

Except for FFI and WWF, which have offices in Kapuas Hulu, most of the nationally implemented CSOs do not consider Kapuas Hulu a priority area. In fact, they have only conducted specific and temporary projects or activities in the area and they work in many other parts of Indonesia.

\subsubsection{Duration and intensity of engagement in Kapuas Hulu}

The duration and intensity of CSOs involvement in Kapuas Hulu are variable. A large range of patterns exists and it seems difficult to define clear categories. Some CSOs have worked in Kapuas Hulu for a very long time (18 years for WWF) and others for a very short time (a few months for JKPP). Some CSOs had just one unique project in Kapuas Hulu (Tropenbos, FWI) and other had many projects (PPSDAK, Riak Bumi). Some CSOs conduct intense activities with daily involvement but others are involved indirectly or to a certain timeframe. While some projects or activities are very short, others have durations of 2 or 3 years. In addition, while some CSOs conduct projects in a clearly defined area, others are involved 
in advocacy or community support, without clear limits in time and space. Thus, it is extremely difficult to build a simple typology that encompasses duration and intensity of involvement without oversimpliflying. Nevertheless, some trends can be highlighted:

- CSOs which are not based in West Kalimantan are the ones which have conducted just one project in Kapuas Hulu. Out of nine CSOs implemented at the national scale in Java Island or outside Indonesia (WRI), seven have conducted a unique project in Kapuas Hulu. These projects had a duration of a few months to 5 years.

- Most of the regionally implemented CSOs have conducted at least two or three projects/activities in Kapuas Hulu. However, compared to the time between their first and their last activity, it seems that most of them were not intensively and continuously involved in Kapuas Hulu. Indeed, it seems that these CSOs usually work in many regencies across West Kalimantan and that Kapuas Hulu is not the easiest place to reach. They were quite active during some periods in Kapuas Hulu but sometimes they had no involvement for a few years.

- NGOs which have an office in Kapuas Hulu are the ones which are permanently working in the field. Their actions are included in a longterm strategy of action in Kapuas Hulu. Their proximity to the field gives them the opportunity to be intensively involved in Kapuas Hulu. These NGOs conduct daily activities in Kapuas Hulu either in the field or in their office.

\subsubsection{Indonesian CSOs legal status}

There are two main legal forms for NGOs in Indonesia: associations (perkumpulan) and foundations (yayasan). Research centers have a particular status that we have not studied in detail. Two of them are based in Indonesia and need an authorization from the Indonesian government to implement research projects. The mass-based organization AMAN has a particular Indonesian status named Ormas (organisasi masa). This organization includes thousands of indigenous communities from all over Indonesia.

In 2012, out of 19 studied NGOs, 12 are associations (perkumpulan) and 7 are foundations (yayasan). Although most of the international NGOs started their activities in Indonesia under country programs, they subsequently founded national
NGOs to continue their long-term activities in Indonesia. Actually, most of the international NGOs have founded yayasan based in Jakarta so they can engage in long-term activities in the field. Out of the six studied national CSOs, two have officially founded a regional antenna in West Kalimantan (WALHI-KalBar and AMAN-KalBar), which has its own legal status. These regional representations are established as independent CSOs working in West Kalimantan. Even they are linked to their national organization, AMAN-KalBar and WALHI-KalBar have their own structure, organization and budget. In 2012, out of nine regional and local NGOs, seven are established under perkumpulan status. The two others are yayasan but they have already initiated internal discussions about becoming associations. It is interesting to note the dynamic of conversion from foundation to association and the reasons for that.

During Suharto's era, most NGOs chose to have the status of foundation because it was less easily controlled by the State. But in 2008, the government passed a law (Law No. 63) on foundations that framed the organization, rights and duties of foundations. In reaction to this law, it appears that many NGOs which were foundations before have since changed their status or are considering it. In addition, the three new NGOs (Kaban, Lanting Borneo and Sebatopa) founded after 2008 have all chosen to be associations rather than foundations.

NGOs which have changed their status from foundation to association declare that the new regulation on foundations passed in 2008 was not satisfactory in terms of:

- internal organization requirements: decisionmaking process, staff changes, etc.

- flexibility in relation to donors: organization structure

- independence from the government and reporting requirements: control exerted by government.

In general, these NGOs declare that they aim to achieve more flexibility in their internal organization and more independence from the government.

Sometimes we had to act quickly but because of this organization structure (foundation) we cannot. Because of procedures, etc. With foundation, with respect to the law, we were not flexible in our relations with donors, it was more difficult [...] With the procedures, 
we had to report every change in the staff to the Department of Law and Human Rights in Jakarta. It was a lot of work for us... Basically it was also difficult for the board of 11 members to meet all together to take any decision for the foundation [...] Now, as an association, the things are more flexible and simple. We have just registered at the Provincial level in Pontianak at the national agency for politics and communities protection (Badan Kesatuan Bangsa Politik dan Perlindungan Masyarakat) under the State Ministery.

\section{Interview 7, Titian}

We were a foundation but now we have changed to association. The situation changed with the new regulation about foundation. By this new regulation, the government could interfere in the work of foundations. So, we have chosen to become association to avoid that.

Interview 49, PPSHK

Foundations are very strictly regulated by the law on foundations (yayasan). And we also should pay tax. It is why now we (Titian) have changed our status to become association. In terms of the governance of foundation, it is very rigid because it is under a law. We should have an advisory board, an evaluation board, an executive board[...] In association (perkumpulan), you can use whatever you want; you are more comfortable to use your own scheme of organization. There is more freedom.

Interview 29, FFI

Before we were a foundation but we changed to association because of the new regulation on foundations. This new regulation doesn't give enough freedom and rules for NGOs to make empowerment programs for communities. The thing is because under foundation status, there will be a control from the government through monitoring, control, etc.

Interview 50, PPSDAK

\subsubsection{Budgets and fundraising}

According to collected data (incomplete), it is clear that international NGOs permanently based in Kapuas Hulu (FFI and WWF) have much more funds than regional and local NGOs involved in Kapuas Hulu. Indeed, the two newly founded local NGOs (Sebatopa and Lanting Borneo) have small or nonexistent budgets. For regional CSOs, the average annual budget is between IDR 500 million and 1.5 billion (US $\$ 50,000$ to 150,000 ) for all their activities in West Kalimantan. In general, they conduct activities in 4-9 regencies across the province, and Kapuas Hulu is rarely their priority area. Thus, with a rough calculation (annual budget/ number of regencies), we can estimate that these CSOs have around IDR 375 million per year for Kapuas Hulu in the best case and around IDR 55 million per year in the worth case. In contrast, WWF have an annual budget of IDR 11 billion (US\$1.5 million) for West Kalimantan province. With 13 full-time employees and numerous projects in Kapuas Hulu, WWF has an available budget of IDR 3 to 3.5 billion (US $\$ 300,000$ to 350,000 ) per year (Interview 1, WWF). The other major international NGO active in Kapuas Hulu (FFI) has also a large budget of IDR 2 to 2.5 billion (US\$200,000 to 250,000) per year. Thus, there is no comparison in terms of budget available for activities in Kapuas Hulu between these two international NGOs and the local and regional ones. International NGOs have much more funds to implement activities in the field than their local colleagues. While WWF spends its budget in an independent way, FFI has chosen a different strategy. Indeed, FFI finances various regional and local NGOs to conduct specific activities related to FFI's projects in Kapuas Hulu.

While at least 23 CSOs have worked in Kapuas Hulu during the last 20 years, about 40 different donors (see Appendix 9) have been quoted during the interviews (the real number of donors is even probably higher). All of them are international donors. Thus, CSOs working in Kapuas Hulu are totally dependent on international funds. Usually, CSOs get these funds after the submission of a project or program proposal to the donors that accept it or not. While some donors are specialized in specific issues, others finance a wide range of activities.

It has not been possible to study in detail each donor and collaboration among NGOs and donors. However, according to collected data, four kinds of donors have been identified:

- Foundations and non-for-profit organizations: The Ford Foundation, The Samdhana Institute, ARCUS Foundation, etc.

- Governmental agencies: Department for International Development (DFID, UK), USAID, Deutsche Gesellschaft für Internationale Zusammenarbeit GmbH (GIZ), European Union, etc. 
- International NGOs: WWF, FFI, PRCFInternational, etc.

- Private sector: Mercury Bank

Among the interviewed CSOs, the Catholic Organisation for Relief and Development Aid (CORDAID), the European Union, The Samdhana Institute and the Ford Foundation are the most frequently quoted international donors. Others, who were very important in the past, have started to reduce their participation with the interviewed CSOs, e.g. the international foundation OXFAMNovib.

There are different situations among the international NGOs involved in Kapuas Hulu. WWF-Indonesia gets its funds almost exclusively from its WWF international network (WWF-USA, WWF-Germany, WWF-Netherlands, etc.). In contrast, FFI gets its funds from various donors such as governmental agencies (European Union), the private sector (Mercury Bank) and foundations. Thus, in terms of fundraising, WWF-Indonesia is more secure than others, thanks to its powerful international network. In contrast, with European Union, private sector and foundations, FFI faces results obligations. Because of the delays in some projects, FFI did not receive IDR 800 million from ARKUS and IDR 400 million from the European Commission.

For regional and local NGOs, many donors support them through project funding or 2- to 3-year program funding. Regional and local NGOs mainly get funds from foundations and various non-profit organizations. They generally do not receive funds from the private sector. International NGOs such as FFI recently started conducting field activities. Thus, some regional and local NGOs receive significant funds from FFI.

Some NGOs directors criticize the lack of flexibility and the slowness of the funding system. Writing proposals takes a lot of time and resources for most NGOs.

To get US\$100,000-200,000 from donors, you need long time, 6 months at least, sometimes more than 1 year! And we also cannot have a good strategy for funding because if we submit a proposal to donor $\mathrm{A}$, we cannot submit the same proposal to other because there would be a suspicion of double budgeting or something like that. And then we wait... One year for one proposal to hear "sorry we cannot support you" [...] And we cannot use the proposal for other donors because the situation has changed! And we should write again another proposal during at least 2 weeks to 1 month and then we have to wait for another 6 months! While our enemy, the private sector, they make a business plan, submit it and within 2 weeks they get the fund from the bank to destroy the forest. So, we do not have a good system yet in using our own resources as a movement.

Interview 29, FFI

\subsubsection{CSOs general objectives}

Naturally, when we talk about land-use planning, land rights and natural resources management, it includes a wide range of issues and activities. Obviously, all the CSOs which have been involved in Kapuas Hulu since 1992 do not share the same vision and objectives. Furthermore, one organization can be involved in very different kinds of projects or activities. Then, for many CSOs, it appears impossible to strictly classify them. However, we propose a simple three category classification based on interviews and various secondary data. We differentiate the following:

- conservationists

- customary rights defenders

- Socioenvironmentalists.

Out of 23 CSOs, 4 NGOs can be clearly identified as "conservationists". Indeed, these NGOs' priorities are biodiversity and habitat conservation. Their actions and discourses are oriented toward environment protection and biodiversity conservation. All of them are well-known international NGOs:

- Fauna and Flora International

- Greenpeace

- WWF

- Wetlands International.

However, each of these NGOs has its own logic and strategy for conservation purposes. While some of them have conducted conservation projects in protected areas in Kapuas Hulu (WWF, Wetlands International), others (FFI) tried to get concessions from the government to implement a REDD+ project. Finally, Greenpeace have not implemented projects in the field but defend the environment through advocacy and campaigning. Thus, this 'conservationists' category is not a homogenous one but refers to general preferences for a conservation approach. 
These 'conservationists' do not ignore social issues or natural resources management and exploitation. On the contrary, all of them include some issues about 'communities' 'livelihoods', 'indigenous people' or 'sustainable management' in their projects. Actually, these issues are part of their strategy to address their priority objective of conservation.

Out of 23 CSOs, seven CSOs are clearly and selfproclaimed 'community-rights defender' CSOs. Their priority is to enforce community customary land rights and land-use rights. They all share a same priority: supporting communities to defend and get recognized for their customary land rights.

\section{Box 1. Conservation projects in Kapuas Hulu.}

In the 1990s, two international conservation NGOs (Wetlands International and WWF) were the first CSOs to support a conservationist approach in Kapuas Hulu. Both started to work in Kapuas Hulu by developing management guidelines for protected areas. For these NGOs, the objective was to contribute to protect high ecological value ecosystems and their associated biodiversity. Actually, these international NGOs supported the government by designing management plans for the BKNP (WWF) and the Danau Sentarum Wildlife Reserve (Wetlands International). Then, after Wetlands International left the Danau Sentarum area, some local NGOs carried out some short-term projects addressing conservation issues during the 2000s in the newly founded national park and around it. At the same time, WWF continued to work in national parks and started to launch various conservation projects across Kapuas Hulu. More recently, they initiated a landscape approach by supporting the establishment of an ecological corridor between the two national parks. In 2009, another well-known international conservation NGO (Greenpeace) launched a major international campaign criticizing deforestation of primary forests by an oil palm company. Other initiatives were conducted by coalitions that highlight the environmental impacts of oil palm expansion. In 2008, Flora and Fauna International, another international NGO started various conservation projects in Kapuas Hulu. In addition to Orangutan Conservation Project, they conducted a HCVF study and worked on peat swamps conservation. One of their major projects in the regency is a REDD+ project in the Danau Siwan area.
For that, each of them has a particular strategy and area of specialization: community mapping, peoples rights advocacy, law enforcement, capacity building, etc. One of these CSOs is a national mass-based organization (AMAN), another is a national NGO specializing in community mapping (JKPP) and the five others are regional and local NGOs. They are:

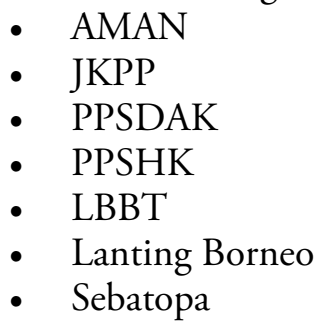

As 'conservationists' tend to use words such as 'local communities' and 'livelihoods' in their discourses, these 'customary rights defenders' have started to use environmental vocabulary in their discourse as well. Thus, 'deforestation', 'climate change' and 'biodiversity' are used by these CSOs to argue against timber or oil palm concessions. But it seems they use environmental arguments as part of a global strategy to enforce people rights. They use, for instance, the well-known idealistic vision of 'conservationist' indigenous communities. But when conservation is in contradiction with people's rights, communityrights defenders reject it. For instance, they often say: "No rights, No REDD" (Interview 3).

The 12 other CSOs have both environmental and community socioeconomic development global objectives. They are not conservationists and are not oriented to community land rights. Actually, these CSOs have various visions and objectives, which change depending on the projects or over time. But the constant is that they usually link people livelihoods/well-being and sustainable natural resources management. Depending on the projects or situations, they are always between environment and livelihood concerns. Thus, these CSOs are more difficult to categorize.

In general, national, regional and local NGOs reject the 'all-conservationist' approach defended by some international NGOs. They always prioritize the local communities' well-being compared to pure conservation issues. In their mind, sustainable natural resource management is important to ensure people's livelihoods. Nature is not all, people are their priority. Thus, while 'environment' is gaining attention among donors, some of these NGOs use the 'conservationist' rhetoric to get more funds for their activities. This strategy is explained by an activist: 


\section{Box 2. Customary rights defenders actions in Kapuas Hulu}

Some CSOs started to work on community land rights issue in Kapuas Hulu at the end of the 1990s. Indeed, JKPP, AMAN, PPSHK and PPSDAK started to support communities in their growing conflicts with logging companies. Sharing the same objective, the respect and recognition of communities' customary land rights, these NGOs had different but complementary approaches. Some were specialized in customary laws enforcement (JKPP); others supported communities by training and helping them to organize themselves (AMAN). Others are specialized in community mapping (PPSDAK). From 1996 to 2008, these NGOs supported the village of Sungai Utik in their conflict with two logging companies. In 1997 and 2003, LBBT supported the Mandalam community to conduct public demonstrations in Putussibau against an oil palm company. Since 1998, PPSDAK have mapped more than 500,000 ha of customary territories in Kapuas Hulu. Recently, a new project has been launched by JKPP and Lanting Borneo (supported by PPSDAK) to map the customary area of 10 villages in conflict with the local government and an oil palm company.

We clearly have a strategy for international donors to talk about environmental issues. Because international want that! But in Indonesia, we are a social NGO, we focus on communities [...] At the international scale, we talk about the environmental impacts, biodiversity, etc. That is why international donors put us as a social and environmental NGO. But this is a strategy for us to package ourselves for international.

Anonymous, from regional NGO

Three general objectives seem to dominate among CSOs involved in Kapuas Hulu. But how are these objectives articulated in action strategies to influence land-use planning and land rights in Kapuas Hulu? What actions are conducted? What kinds of interrelations exist among CSOs and how do they interact with government?

\subsection{Stories of CSOs action situations in Kapuas Hulu}

In this section, we describe four detailed stories of specific CSOs action situations in Kapuas Hulu on land-use planning, community land rights and natural resources management issues.

\subsubsection{CSOs' participation in the Kapuas Hulu spatial plan revision process (2010)}

At the beginning of 2010, the Kapuas Hulu government started to design a new RTRW-K.

\section{International NGOs' participation}

In order to advise a professional consulting company in charge of writing the spatial plan, BAPPEDA formed a technical working group (tim teknis) in early 2010. In addition to local sectoral agencies (agriculture, forestry, transmigration, fisheries,

\section{Box 3. The socioenvironmentalist projects in Kapuas Hulu}

Socioenvironmental objectives refer to a wide range of projects and activities, which integrate both human and environmental factors. For example, in 1997, a local NGO called Dian Tama started to support communities inside the Danau Sentarum area by helping them to manage in sustainable ways non-timber forest products. This project aimed to improve communities' livelihoods by training and helping them to market their products. This project in Danau Sentarum was followed by others conducted by a number of different NGOs. In general, the objectives were to enhance communities' livelihoods and improve natural resources management. For instance, some other CSOs (Riak Bumi, CIFOR, Tropenbos) tried to promote collaborative management in the Danau Sentarum National Park. These projects admit that sustainable management of protected areas could be reached only with improvement of local communities' livelihoods. In terms of advocacy and campaigning, most of the actions carried out by NGOs mix both social and environmental arguments. WALHI and Sawit Watch often criticize oil palm projects for their social and environmental impacts. Various research projects carried out by CIFOR, Tropenbos and WRI are also classified in the socioeconomic justice category. 
etc.), three CSOs were involved as members of the technical working group. Two of them were international conservation NGOs that were very active in Kapuas Hulu: WWF and FFI. The third nongovernmental stakeholder involved was an Indonesian private expertise cabinet called SEKALA $^{15}$. It had been working in Kapuas Hulu since 2009 on a pilot project for an international research center (WRI). While the law does not explicitly required CSOs' participation, the technical working group's coordinator from BAPPEDA seems proud to have been the initiator of this CSOs' participation. According to him, most of his colleagues in BAPPEDA and other governmental agencies were did not favor CSOs participation. But as coordinator of the process, he supported the idea of CSOs participation.

At the beginning, there were oppositions in my office (BAPPEDA) because NGOs are viewed by many civil servants as outsiders and even sometimes as enemies. The other stakeholders of the technical working group were all from the government. Of course, at the beginning that was not easy but I tried to convince the government that NGOs could bring a good contribution to the process. And finally it worked and the NGOs joined the technical working group!

Interview 19, BAPPEDA

There is something very interesting here. Actually, Kapuas Hulu is the only place in West Kalimantan and maybe in Indonesia where NGOs have been invited to participate to the process as members of the Technical working group.

Interview 19, BAPPEDA

This civil servant (the BAPPEDA coordinator) played a role in the active participation of CSOs. It seems that compared to the usual way of thinking among civil servants, he was open-minded and had a progressive attitude to CSOs' participation in the decision-making processes. Actually, before the process, he was already friendly with some NGOs

15 SEKALA was the Indonesian partner of the WRI, an international think tank based in the US. WRI was conducting a large project on sustainable palm oil (POTICO) in Indonesia. They collaborated with SEKALA, which was in charge of the fieldwork and interactions with authorities, companies and communities. SEKALA is not strictly a CSO; it is considered to be the local representative of WRI, an international CSO. In addition, during the fieldwork, most of the NGOs and government civil servants thought that SEKALA was an NGO. staff. However, as a coordinator of the spatial planning process in Kapuas Hulu, he was pursuing clear objectives. Supporting CSOs' participation was also part of his strategy to reach its own professional objectives. He thought that CSOs could facilitate and bring positive inputs into the process. He supported CSOs participation because they had many data, their staff had good knowledge and skills and their networks would be helpful.

There are three things that make me support NGOs participation: First, they have data resources which could contribute to facilitate the work of the technical working group and consultants. Their data could help to make the spatial planning data more accurate and clear. Second, NGO staff are experts in their domain of activity. They have good skills and knowledge. Third, NGOs have a network in West Kalimantan Province and in Jakarta that can contribute to bring positive ideas in the RTRW-K Kapuas Hulu revision process.

Interview 19, BAPPEDA

Indeed, the three CSOs involved as members of the technical group had data on Kapuas Hulu, highly skilled employees and extended networks. The two international NGOs (FFI and WWF) had data on biodiversity and ecosystems across Kapuas Hulu. Among their staff, they also had geographic information systems (GIS) and spatial planning experts. Sekala, the consulting company had specific data on land suitability for oil palm plantations and highly skilled staff. These three CSOs had national and international connections. Finally, all of them were interested in land-use planning issues.

In addition, these three CSOs had never openly confronted or criticized the Kapuas Hulu government. They all had appeased relations with the local government. Before joining the spatial planning process, they were all trying to collaborate with governmental agencies (forestry, tourism, national parks, BAPPEDA, etc.) through formal (Memorandums of Understanding) and informal processes. They often organized workshops and seminars to present their activities and objectives and discuss with governmental stakeholders. For the two international NGOs (FFI and WWF), their local implementation in the regency capital Putussibau was also important. Thanks to their large offices and daily activities in Kapuas Hulu, they were obviously more visible than others. 


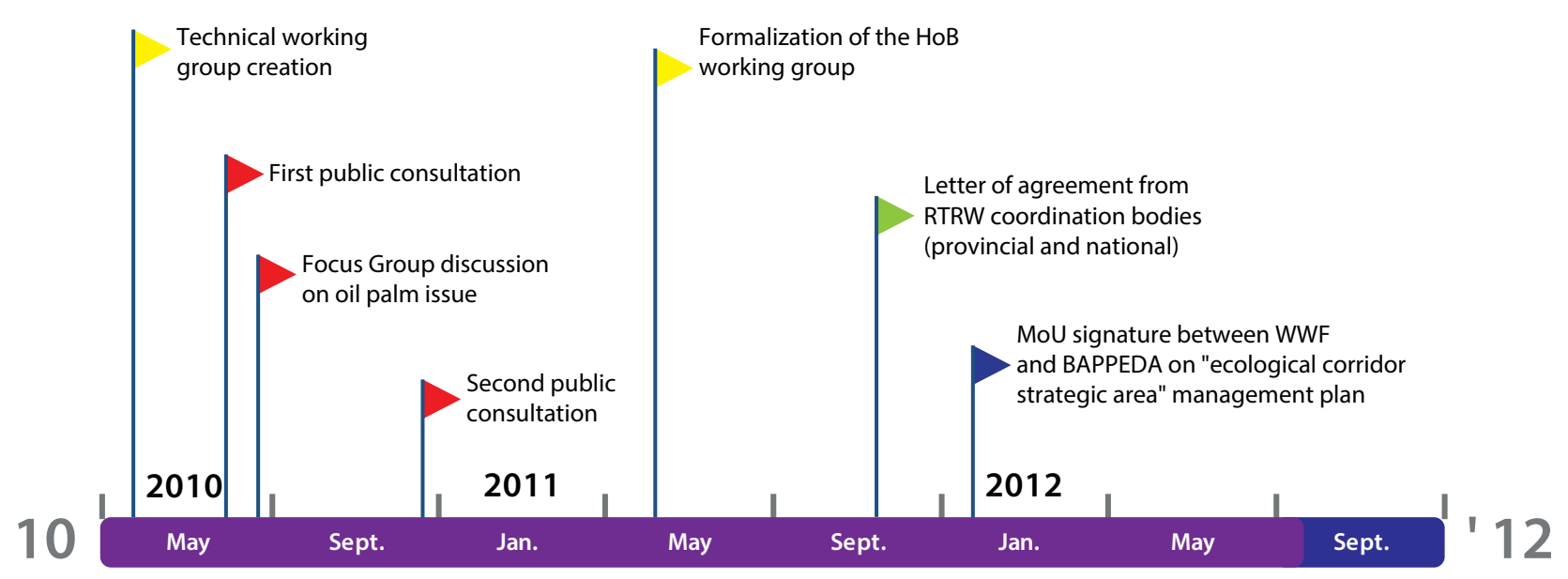

CSOs participation to the technical working group

Figure 12. Major events related to the RTRWK revision process in Kapuas Hulu (2010).

Among the other CSOs involved in Kapuas Hulu in 2010 and before, none were invited to participate as members of the technical working group. It seems that these local and regional CSOs were less known and trusted by the government. Indeed, most of them were not based in Kapuas Hulu and did not have daily or intensive activities in the regency. Most of them had only an office in Pontianak the West Kalimantan capital. In addition, they were not actively interacting with the Kapuas Hulu government. Some of them only worked in the Danau Sentarum National Park and then directly coordinated with the national park agency situated outside Kapuas Hulu. Others were working in Kapuas Hulu as subcontractors for FFI's projects and were not conducting their own projects. Finally, others had historical confrontational relations with the government. They always kept their distance from all forms of authority.

In 2010, when the technical working team was founded (Figure 12), FFI, Sekala and WWF were the most active CSOs on land-use planning issues in Kapuas Hulu. To sum up, compared to others, these three CSOs were active in the field, cooperating with the local government, reputed to have expertise, data and international connections.

\section{CSOs' roles and objectives}

Thanks to their status, the three CSOs (FFI, Sekala and WWF) actively participated in the meetings of the technical working group, in the focus group discussions and in the public consultations. They were also actively involved in an informal process of discussions and data collection with the BAPPEDA coordinator. In contrast, out of the 23 CSOs studied, only a few local and regional CSOs participated in public consultations.

Through an intense informal process, the three CSOs provided useful data for the spatial planning process. Indeed, the CSOs had frequent informal discussions ${ }^{16}$ with the BAPPEDA coordinator. According to them, the informal discussions were more open and constructive than the formal meetings. They shared data and they also tried to convince the BAPPEDA coordinator to support their opinions during official meetings. The CSOs and the BAPPEDA coordinator had good relations. Sometimes, a GIZ-ForClim program ${ }^{17}$ staff member (Component 3) and a CIFOR staff member (CoLUPSIA project) joined the informal meetings. According to the BAPPEDA coordinator, the CSOs played a significant and positive role in the process. Shared data and knowledge were appreciated as significant contributions to the process.

Our colleagues from NGOs gave us the latest data from the field. Many things! [...] Our colleagues from WWF, FFI always made positive contributions in the process. [...] Particularly, we got a big contribution from WWF. Through GIS data, maps but also they tried to involve

16 These informal meetings were often held in the FFI office. 17 Forests and Climate Change Programme conducted by the German Development Agency (GIZ) in Kapuas Hulu. 
by sharing knowledge. They tried to share their opinions about Kapuas Hulu land-use planning and what it should be. FFI and SEKALA contributed as well positively. By this sharing process of knowledge, these NGOs could influence the other participants.

\section{Interview 19, BAPPEDA}

NGOs seem proud of their contribution to this process. They have been key actors in the spatial plan revision process in Kapuas Hulu. They provided some data that the government did not have. According to them, the informal process was an important platform for them to influence the process. In particular, WWF states that their data were key to the process. The WWF strategy to influence the spatial planning revision process was to provide data and knowledge to BAPPEDA and other government stakeholders.

Without the support from NGOs, they (the government) did not have anything. Without our data they did not have data to make the spatial planning document. We bring all our environmental data, our maps, our HCVF study, etc. That was very transparent, that was in our interest as well. [...] It was very good to give our contribution to the regency government. That was the way for us to influence the process and support our vision.

Interview 1, WWF

CSOs shared their data and had a proactive attitude in order to influence the spatial planning process. Despite slight differences and priorities, the three CSOs shared the same general objectives on conservation and sustainable development for Kapuas Hulu. Thus, during discussions and meetings, they all tried to convince the other stakeholders to limit or stop expansion of land-use status suitable for deforestation and oil palm plantations (APL, APK). They also tried to draw the attention of others to the importance of protecting the national parks and their buffer zones (for Danau Sentarum). To sum up, their main preoccupations were the

- oil palm sector expansion and its environmental impacts through deforestation and chemicals uses;

- conservation of natural areas (national parks, primary forests and peat swamps);

- development of sustainable livelihoods sources for communities such as ecotourism;

- climate change mitigation.

(Interviews 1, 11, 20, 53, 59 and 62)
While the three CSOs shared a same general vision, they individually defended specific and localized demands (Figure 13). As members of the working group, CSOs presented their ongoing projects, future objectives and general vision of what should be Kapuas Hulu new spatial plan for the next 20 years during meetings. WWF proposed recognizing its 'ecological corridor' project area between the two national parks as a regency strategic area Kawasan Strategis Kabupaten, KSK) (Interview 1 and 11, WWF). FFI pressed the government to change the status of some peat swamp areas in order to avoid deforestation (Interview 20 and 53, FFI). In one of these areas, FFI aimed to develop a REDD+ project. Sekala proposed changing the status of a forested area in order to avoid deforestation and conversion to an oil palm plantation. In compensation, Sekala proposed to change the statu of a non-forested area from HPT to APL.

Most of these demands were about land-use planning and land-use designation. It was the responsibility of the forestry agency to accept or refuse it before communicating with higher governance levels (province and national).

\section{Relations among stakeholders}

The three CSOs talked about their opinions and visions for Kapuas Hulu spatial plan with the BAPPEDA coordinator in several informal and formal meetings. There was at least one formal meeting per week and at least two or three informal discussions per week (Interview 1, WWF; Interview 19, BAPPEDA; Interview 20, FFI). They tried to convince the BAPPEDA coordinator, the forestry and plantation agency, the national parks and the consultancy company in charge of writing the official document (Figure 14). However, most of the other governmental members of the working group were not very involved in the discussions. It seems that most of them were not very active in the process and attended very few meetings. Meeting attendance lists suggest that NGOs (FFI and WWF) were more frequently present during the meetings than most of the governmental agencies.

The NGOs faced strong opposition from the forestry and plantations agency and from communities' representatives on the oil palm issue. For the head of Kapuas Hulu regency and many civil servants, oil palm expansion appears necessary to promote economic development in the regency (Interview 19, BAPPEDA; Interview 32, GIZ; Interview 34, plantation agency). During the spatial planning 


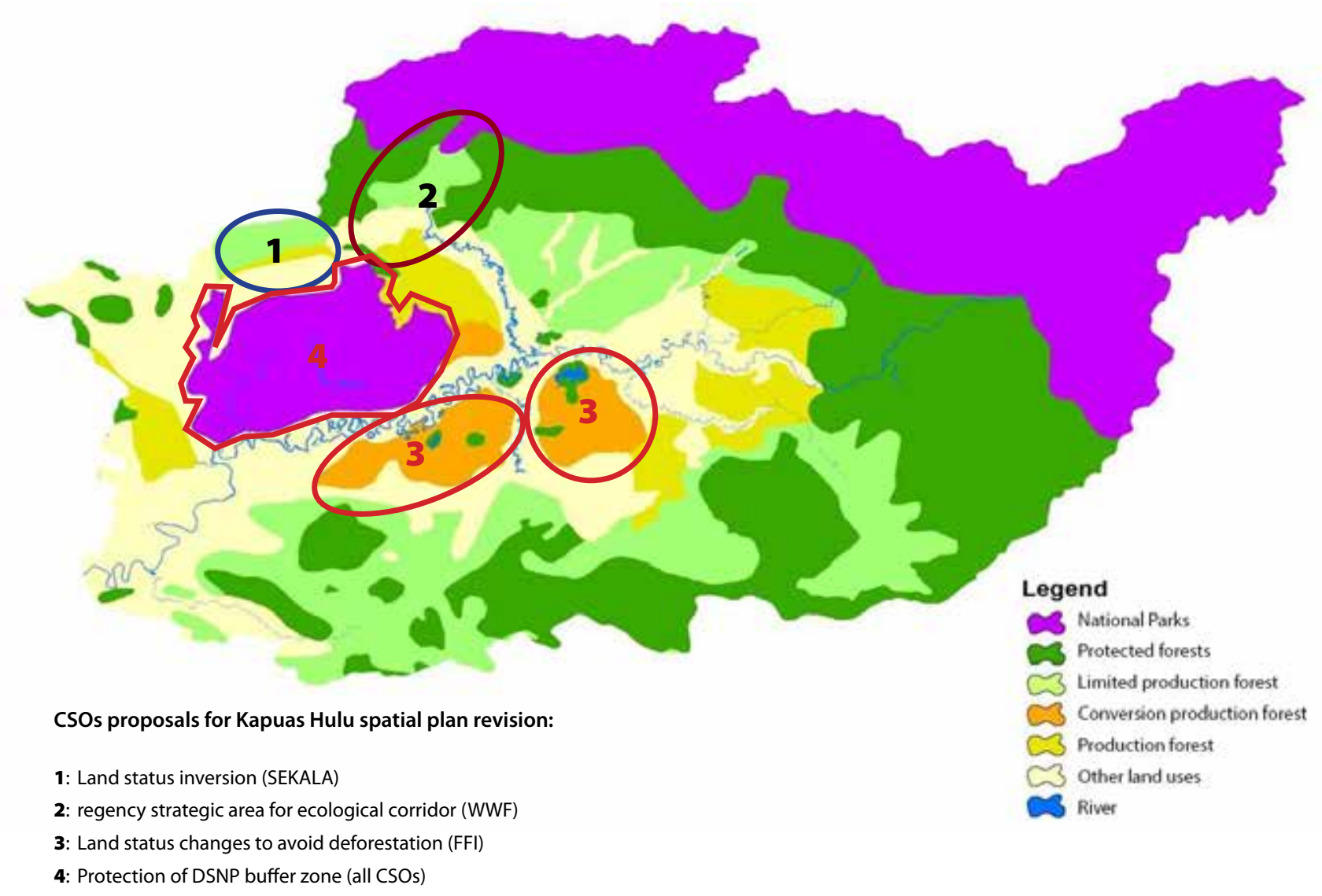

Figure 13. CSOs proposals for RTRW-K revision in Kapuas Hulu (2010).

revision process, the forestry and plantations agency representatives always opposed to NGOs demands to limit oil palm expansion. In contrast, they asked for more lands for conversion into industrial plantations. The confrontation between CSOs and the forestry and plantations agency culminated during a focus group discussion organized in August 2010 (Interview 53, FFI). While WWF made a presentation entitled "Climate change, concept of development and the spatial plan of Kapuas Hulu", the plantation agency presented "After logging forests, that is time for oil palm" (personal communication from WWF). During the discussions, WWF, Sekala and FFI (supported by a GIZ-ForClim program staff and a few communities opposed to oil palm, invited by WWF) criticized the oil palm sector and its environmental and social impacts. In contrast, the plantation agency and representatives from oil palm companies and some communities' representatives (invited by the oil palm companies) pointed out that the NGOs were demonizing the oil palm sector. In return, they criticized the "unrealistic" and "antidevelopment" point of view of conservationist NGOs (Interview 41, BAPPEDA; Interview 60, CIFOR).
During one focus group discussion on climate change and oil palm, some oil palm companies were invited. They came and they brought with them community customary leaders from Badau district to support them. [...] At that time, there were a very hot debate between WWF, FFI and communities from Embaloh district on one side and the plantation agency, the companies and communities in the other side. [...] There were many people, around 40 . And the debate was hot! The NGOs wanted to decrease the deforestation and forest degradation in Kapus Hulu. Their objective was to stabilize, to stop the oil palm extension trend. In contrast, the others stressed the economic potential of oil palm.

Interview 41, BAPPEDA

Finally, this focus group discussion was an example of the strong antagonism that existed between the prooil-palm extension and the anti-oil-palm extension in Kapuas Hulu. While NGOs seem to share the same negative opinion about environmental and social impacts of oil palm plantations, the local plantation agency and its allies from the private sector strongly 


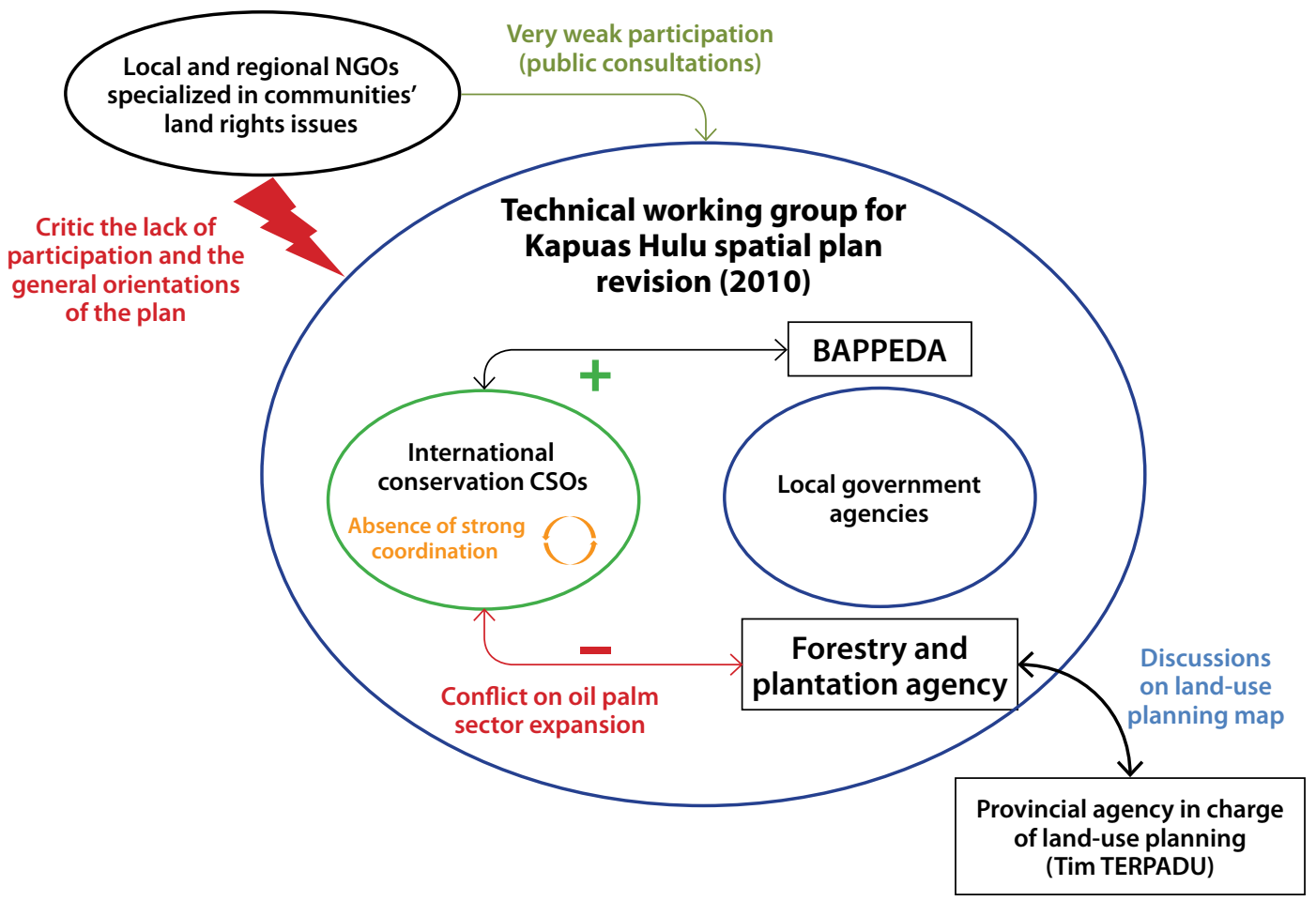

Figure 14. CSOs participation in Kapuas Hulu spatial planning process in 2010.

defend the economic value of the oil palm sector for Kapuas Hulu. Both sides have allies among the local communities and invited them to participate during the focus group discussions.

\section{What result for CSOs?}

For CSOs, the Kapuas Hulu spatial plan revision is a mixed picture (Figure 15). In terms of spatial structure for strategic development (structure ruang), WWF got very positive results. Indeed, two of the three designated regency strategic areas (KSK) are related to conservation issues. First, Danau Sentarum National Park has been classified as a strategic area for ecotourism. Second, the ecological corridor between the two national parks has been classified as an ecological corridor strategic area.

So, they accommodate our idea about the conservation. In the Kapuas Hulu spatial planning process, they included ecotourism as a core business, as an important issue for $\mathrm{KH}$. They also incorporated our idea about the ecological corridor in KSK (Kawasan Strategi Kabupaten). Both became regency strategic areas. Actually there are $3 \mathrm{KSK}$ : (1) the ecological corridor between the two national parks, (2) the ecotourism area in the Danau Sentarum National
Park, and (3) the agropolitan area dedicated to agricultural activities in the south of the regency.

Interview 1, WWF

WWF seems to get more positive outcomes from the process than other CSOs. Two reasons can explain this. First, WWF gets outcomes on strategic areas and not on land-use designation. Strategic areas are less constraining than land designation status. Second, WWF has been present in Kapuas Hulu since 1995 and initiated $\mathrm{HoB}$ in Indonesia. While Kapuas Hulu is included in the $\mathrm{HoB}$ area, ecotourism strategy and ecological corridors are parts of the HoB official strategic plan. Therefore, while WWF defended the 'ecological corridor' idea, the local agency for planning and development (BAPPEDA) signed a Memorandum of Understanding $(\mathrm{MoU})$ with them in 2012. This MoU stipulates that WWF is in charge of supporting BAPPEDA to write a management plan for the area. ${ }^{18}$ WWF has conducted research and projects in the area since 2005. They are currently preparing the management plan for the ecological corridor strategic area. But the potential new land-

18 In order to develop a strategic plan for ecotourism in the DSNP, BAPPEDA has signed a similar MoU with the GIZForClim program. 


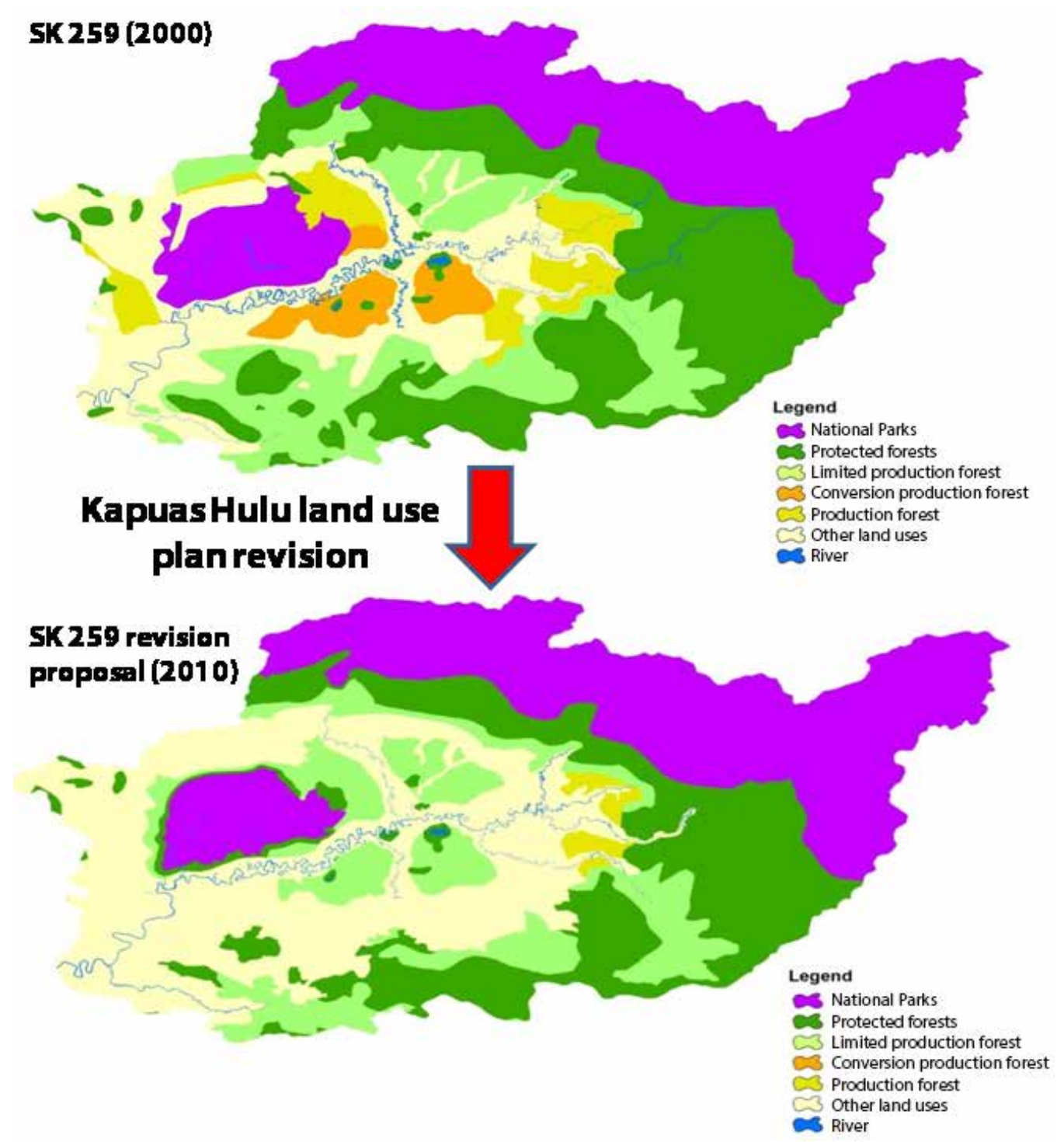

Figure 15. Land-use planning changes after the RTRWK Kapuas Hulu revision process. Source: BAPPEDA (2011)

uses status will probably threaten their projects in the field.

In terms of land-use planning, the results at the end of the RTRW-K revision process in 2010 were less positive than expected by CSOs:

- The buffer zone of the DSNP disappeared. It was replaced by just a $1.5 \mathrm{~km}$ wide conservation forest (Hutan Lindung) compared to the first draft (supported by CSOs) which proposed at least an $8 \mathrm{~km}$ wide buffer zone (Interview 41, BAPPEDA).

- The area opened for APL in Kapuas Hulu increased by $63 \%$ (+ 370,000 ha) (Table 2).

- Protected forests areas in Kapuas Hulu decreased by $14 \%(-114,000 \mathrm{ha})$ (Table 2$)$.

- The proposal made by Sekala to change the status of an area in the north of the DSNP in order to avoid deforestation has not been taken into account (Figure 15).

In contrast, a positive change in terms of land-use planning for NGOs has been the status changes of about 107,000 ha of HPK into HPT. Thus, these peat swamps area are protected against land conversion. FFI is currently trying to implement a REDD+ project in an area of 45,000 ha previously classified as HPK. More generally, 52.8\% of the Kapuas Hulu area remains under protection status. It can be considered to be a good situation for conservationist NGOs.

While the land-use plan of West Kalimantan is still not validated and legalized, it is impossible to know if the final results will satisfy to the CSOs involved in the Kapuas Hulu spatial plan revision. 
Table 2. Details of land-use designation status changes between old and new LUP in Kapuas Hulu.

\begin{tabular}{|c|c|c|c|c|c|c|}
\hline \multirow[b]{2}{*}{ Status (in English) } & \multicolumn{2}{|c|}{$\begin{array}{l}\text { SK } 259 \text { (land-use plan for } \\
\text { Kapuas Hulu since 2000) }\end{array}$} & \multicolumn{2}{|c|}{$\begin{array}{c}\text { SK } 259 \text { revision proposal for } \\
\text { a new land plan in Kapuas } \\
\text { Hulu (2010) }\end{array}$} & \multicolumn{2}{|c|}{$\begin{array}{l}\text { Changes between SK } \\
259(2000) \text { and the new } \\
\text { proposal issued in } 2010\end{array}$} \\
\hline & $\begin{array}{l}\text { Surface } \\
\text { (in ha) }\end{array}$ & $\begin{array}{l}\text { Percentage } \\
\text { of the total } \\
\text { area (\%) }\end{array}$ & $\begin{array}{l}\text { Surface } \\
\text { (in ha) }\end{array}$ & $\begin{array}{l}\text { Percentage } \\
\text { of the total } \\
\text { area }\end{array}$ & $\begin{array}{l}\text { Changes } \\
\text { in ha }\end{array}$ & $\begin{array}{c}\text { Changes } \\
(\%)\end{array}$ \\
\hline National parks & 939329.52 & 30.3 & 935512.03 & 30.2 & -3817.49 & -0.4 \\
\hline Protected forests & 815186.84 & 26.3 & 701402.48 & 22.6 & -113784.36 & -14.0 \\
\hline Limited production forest & 481623.48 & 15.5 & 472341.92 & 15.2 & -9281.56 & -1.9 \\
\hline $\begin{array}{l}\text { Conversion production } \\
\text { forest }\end{array}$ & 107470.26 & 3.5 & 0.00 & 0.0 & -107470.26 & -100.0 \\
\hline Production forest & 171082.26 & 5.5 & 35456.63 & 1.1 & -135625.63 & -79.3 \\
\hline Non-forest land-uses & 583882.67 & 18.8 & 953859.32 & 30.8 & 369976.65 & +63.4 \\
\hline TOTAL & 3098575.03 & 100.0 & 3098572.38 & 100.0 & -2.65 & 0.0 \\
\hline
\end{tabular}

Source: BAPPEDA (2011)

The lack of local and regional CSOs participation While three CSOs (FFI, WWF and Sekala) were invited to participate actively in the spatial planning revision process in Kapuas Hulu, other CSOs (particularly regional and local NGOs) were not involved at all. However, as is required by Law UU 26/2007, public consultations were organized in Putussibau at the beginning (July 2010) and at the end (December 2010) of the process.

Because of his proactive attitude during the process, the FFI coordinator for Kapuas Hulu was in charge of sending the invitations to CSOs and communities' representatives. With the consent of the BAPPEDA coordinator, in addition to the whole technical working group and some representatives of the private sector, 11 civil society organizations (including national, regional and local CSOs), 5 communities' representatives and 4 journalists were invited. Among the CSOs invited, all of them (except one local NGO) were based in Pontianak, the capital of West Kalimantan.

Despite the official invitations, very few NGOs joined the public consultations on Kapuas Hulu spatial plan revision. Among the factors invoked by CSOs to explain their absence, we can list the following (Interview 4, Kaban; Interview 6, PRCF; Interview 8, Dian Tama):

- The fact that invitations were sent too late for NGOs based in Pontianak (16 to 18 hours from Putussibau by car or bus)
- The transport cost from Pontianak to Putussibau was too high for NGOs (between IDR 600,000 and IDR 2 million round-trip per person).

- Some NGOs invited were not working in Kapuas Hulu anymore. Others were working in very localized areas and thus were not interested in a regency-scale approach.

- Most of the NGOs were not specialized in spatial planning issues.

- Some NGOs knew that WWF and FFI were already involved as members of the technical working group. They more or less trusted these international NGOs to advocate for them on environmental issues.

In RTRW-K Kapuas Hulu, we have been invited by BAPPEDA one time but we did not go. It was far and the invitation was too sudden, we did not have time to prepare. We received the invitation just one day before the meeting, that was clearly too late because it takes 18 hours to go to Putussibau (from Pontianak)... So I think that was just a formality, BAPPEDA did not really want to invite us.

Interview 4, KABAN

The three CSOs involved as members of the technical working group focused on environmental issues. Two of them, the most influential, were international conservationist NGOs. Although all their demands were not accepted, these NGOs seem quite satisfied with the participative process used 
by the government. In contrast, some of the local and regional NGOs, especially the ones specialized in customary land rights defense were very critical of the process. They criticized it as a top-down approach without real participation of the civil society and communities. Some of them criticized the local government and accused it of being corrupted by oil palm companies. Finally, some NGOs pointed out that public consultations are not adapted to participation.

We participated in one or two public consultations but not in the decision-making process. In my opinion, the RTRW-K in Kapuas Hulu is not participative at all. It is a top-down approach. There was no real participation of the communities; the government decided everything by itself about the spatial planning.

Interview 15, Lanting Borneo

LBBT has not been invited to participate in the RTRW-K Kapuas Hulu revision process. Anyway, it is difficult for me to say that this project is good because usually the issue is only about money and large investment... The customary rights, people rights on their lands are not recognized in these policies.

Interview 44, LBBT

Yes I know the RTRW-K Kapuas Hulu process but I am pessimist because I know how these people work [the government]. I am pessimist because their perspective is that all the Indonesian area is the property of the State, the forests are property of the State... But nothing for the communities...

Interview 44, AMAN

According to me, the communities which followed the meeting did not understand very well... The thing is that the government already has plans or results, they invite people but these people invited do not really understand the situation... Yes, they can participate. But they do not understand, they do not have the skills to speak about that [...] In public consultation, the government presents its plan and statistics. But the communities do not have the skills to analyze and react to the information given by the consultant. It is also too fast to understand and react. Even me, I did not understand. How it would be possible when you are invited Monday and the program take place Tuesday. It is just one day, you cannot be prepared to comment or give arguments... In my opinion, the process is not really participative. It should be longer to give to communities enough time to analyze and comment the data... It should be something like a workshop! And also the number and diversity of people was not enough. For these public consultations, only the people who have access to Putussibau, the head of few tribes and some people from NGOs have been invited. But not people from everywhere!

Interview 54, Lanting Borneo

\subsubsection{Civil society coalition for sustainable and fair RTRW-P in West Kalimantan (2012)}

This civil society organization is not limited to the Kapuas Hulu regency, but we have chosen to present it because of its potential impacts on the Kapuas Hulu spatial plan. Until the spatial plan is legally validated through a local regulation, changes may happen.

\section{The roots of the coalition}

The West Kalimantan spatial plan (RTRW-P KalBar) revision process was conducted in 2010 under the authority of the provincial public works agency (PU). However, some NGOs denounced the lack of civil society participation and consultation during the process, the lack of transparency and the general orientation of the new spatial plan which was favorable to 'capitalist' investments.

The law and government regulations include the community participation (PP68/2010). The communities have to participate in issuing the spatial planning and that is why the coalition tries to participate through this regulation. The problem is that there is no participation of NGOs or communities in the process in KalBar. Actually the participation of communities is supported by law but in fact the process of spatial planning in KalBar which will be in place for 20 years is not involving the communities or NGOs. Interview 9, Gemawan

... (during the public consultations for the revision of the RTRW-P West Kalimantan) the communities were not welcome. In principle, these meetings were for public participation but the NGOs were invited only to hear, to listen, they had no space to present or to give their opinion. That was really restricted. [...] that was not possible for us to influence the process. We were there only as passive participants. [...] Actually, the public work agency only gave 
general material but nothing specific, no details, no maps. [...] That was only broad discussions.

Interview 9, Gemawan

There was no space for NGOs and communities to talk about RTRW-P West Kalimantan. But in theory, according to the policy and the legal procedures on spatial planning, the government must involve the indigenous people and NGOs. But in reality they didn't! That is the real conditions of West Kalimantan. There is the theory in the law and the reality in the field, and it is very different!

Interview 5, WALHI

PU invited us for a public consultation. But it was an arranged drama... The meeting was just an occasion for them to make a show. Actually, a drama... The government already has its plan and they keep going ahead with their plan no matter what civil society think...

Interview 45, AMAN

Two advocacy NGOs (Gemawan and WALHI) started to discuss the idea of building a coalition to advocate the revision of the RTRW-P with WWF. Some local NGOs supported the idea during numerous informal discussions in 2011 (Interview 47, Gemawan).

\section{A multistakeholders' coalition with shared duties}

The coalition became active in early 2012 in Pontianak. It was decided by the three initiators that it would be coordinated by the local NGO specialized in advocacy: Gemawan. Progressively, various NGOs (mainly regional and local NGOs) and community-based organizations joined the coalition. The coalition was informal and participation was free and open. There was no list of participants. However, according to one of the coordinators from Gemawan (Interview 9 and 47, Gemawan), more than 40 NGOs and community groups have joined the coalition. Some of the most active NGOs are WALHI, PPSDAK, LBBT, WWF, Kontak Rakyat Borneo, Titian, PRCF, AMAN KalBar, Institut Dayakology and Sawit Watch. While WALHI and Gemawan are strongly involved in advocacy activities, WWF prefers to take a more background role. Some others are not really active; they just support the idea and the ideal of the coalition. A range of community-based organizations joined the coalition, such as KNPS (fishermen group), SPKL (farmers group) Pamliki (communitybased organization in Sintang), Masyarakat Korban investasi (communities victims of investment), STSD (farmers' union from Sambas). From Kapuas Hulu, no community-based organization and only one local NGO (Lanting Borneo) have joined the coalition

As coordinator of the coalition, Gemawan has a central role in the coalition organization. Other NGOs have provided a substantial amount of data and inputs during the numerous meetings. Finally, some members of the coalition played a more passive role.

\section{The strategy and the working plan}

The coalition organized a 2-day workshop in Pontianak at the end of January 2012. According to the coordinators, more than 40 NGOs participated in the event. The objectives were to discuss the West Kalimantan spatial plan issue, to define a strategy for civil society coalition and to make a working plan. After long discussions, the coalition decided to engage a mixed strategy roughly divided into three points:

- lobbying the DPRD

- organizing a demonstration at the provincial level (in Pontianak)

- a media campaign at the provincial and national level.

Following the technical process, the RTRW-P must be legalized through a raperda issued by the DPRD. Then, the only solution for the coalition was to lobby the DPRD. According to an NGO activist, the DPRD would probably be more open to civil society participation because the members are regionally elected. Then, the coalition chose to put pressure on the DPRD because their position depends on the people who elect them.

The Public work agency (PU) is an executive body. But DPRD (the regional legislative assembly) is elected by the people, the communities. That is why they should try to meet the community demands. Because if they don't, communities will not vote for them again for the next elections. That is what determined our choice to lobby the DRPD.

Interview 9, Gemawan

In addition to the lobbying strategy, the coalition chose to organize a demonstration in order to put more pressure on the DPRD through media coverage of the public protest (Figure 16). Actually, the aim of the demonstration was to get the attention of the DPRD by showing them a large public mobilization. 
This strategy mixes advocacy and contestation and negotiation and collaboration with the DPRD. The media is used to make the issue more visible in the public space in order to get more support from communities and citizens.

The working plan decided during the workshop included the following (personal communication from Gemawan):

- The realization of a survey about the perception of local communities on RTRW-P. Unfortunately, because of lack of funds, this study has not been realized yet.

- Making giant banners for the demonstration in Pontianak. Banners were considered to be tools for communication with people and media during the demonstration.

- The consolidation of relations with students' organizations to invite them to participate in the demonstration.

- Consolidation with communities which faced land or natural resources conflicts across West Kalimantan. Each NGO had the mission to do that in one or two regencies. WWF and Lanting Borneo were in charge of Kapuas Hulu. The coalition prepared material with a policy review and some key issues. The goal was to motivate communities to come to Pontianak on 30 April 2012 for the demonstration.

- The coalition planned to press the DPRD to organize a public consultation and make the process participative.
- Some key people from NGOs (six) with good political connections will discuss with the DPRD factions. They were the lobbyists of the coalition.

- Contacts with media and organization of press conference. The coalition invited various local and national media to explain the situation to them (Pontianak Post, Journal National, KOMPAS, etc.)

\section{The coalition in action and its demands}

Despite a few contacts with some political elites and some articles posted on the Internet in early 2012, the coalition started to act in April 2012. Indeed, on 30 April 2012, the civil society coalition for sustainable and fair spatial planning in West Kalimantan organized a demonstration in Pontianak. As coordinator of the coalition, the local NGO Gemawan was in charge of organizing the demonstration. Together with some other NGOs, they prepared giant banners and printed summaries of their demands. Many activists from local NGOs participated in the public protest. Some indigenous people communities from various regencies in West Kalimantan came to Pontianak for the demonstration as well. Some of them came far and the NGOs helped them with accommodation and food. The first objective of the demonstration was to press the DPRD to make a commitment on seven points defended by the coalition. The seven demands of the coalition were (Interview 9 and 47, Gemawan):

1. Discussions of the RTRW-P West Kalimantan draft process must be open and participative at both executive and legislative levels.

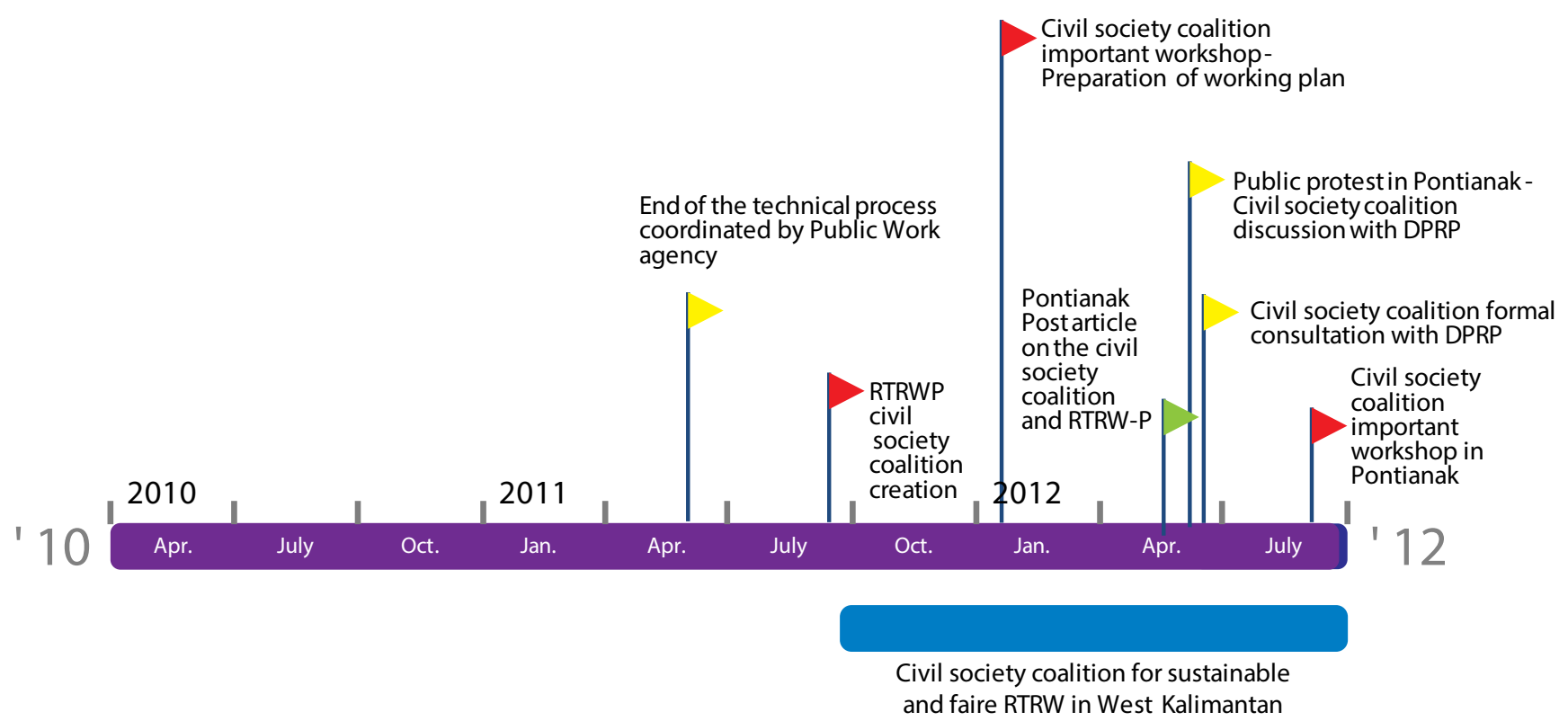

Figure 16. Civil society coalition on RTRW-P West Kalimantan. 
2. The new RTRW-P West Kalimantan must clarify the land status by taking into account the communities' needs in term of cultivated areas and protected areas.

3. The RTRW-P West Kalimantan must protect the food production centers for the communities.

4. The RTRW-P West Kalimantan should not be a means of laundering the violations of the forest area committed by local government (regencies) through oil palm concessions issuance and existing mining operations.

5. RTRW-P West Kalimantan should not facilitate the development of investments that have been proven to cause social conflicts and environmental degradation, such as oil palm plantations, logging and mining industries. The RTRW-P West Kalimantan should give a higher priority to the development of smallholders.

6. RTRW-P Kalimantan must contribute to maintain and improve the ecosystem functions of protected areas in order to avoid widespread flooding in West Kalimantan.

7. The government must protect wildlife habitats both in the cultivation areas and protected areas defined by RTRW-P.

In addition, the coalition quoted various laws and regulations related to spatial planning that theoretically guarantee management rights for indigenous communities and others:

- Strategic Areas of Socio-cultural Value (UU 26 of 2007)

- Protection of sustainable Agricultural Land for Food Security (UU 31 of 2009)

- Protection Areas for Specific Commodities and Locations (Act 18 of 2004)

- Areas for Dryland Agriculture (RTRW-P Law No. 5 of 2004)

The demonstrators went to the DPRD in Pontianak with these seven demands. They met some representatives of the DPRD (Figure 17). According to one of the coordinators of the coalition, some DPRD representatives gave their commitment to the communities and CSOs that they will take into account their demands and discuss them. However, the activists still seem very cautious:

The minimal target has been filled because the DPR gave its commitment to the communities and civil society. But we still need to monitor because all our demands are still in process.

Interview 9, Gemawan

The civil society coalition conducted its strategy to inform the media about the issue of West Kalimantan

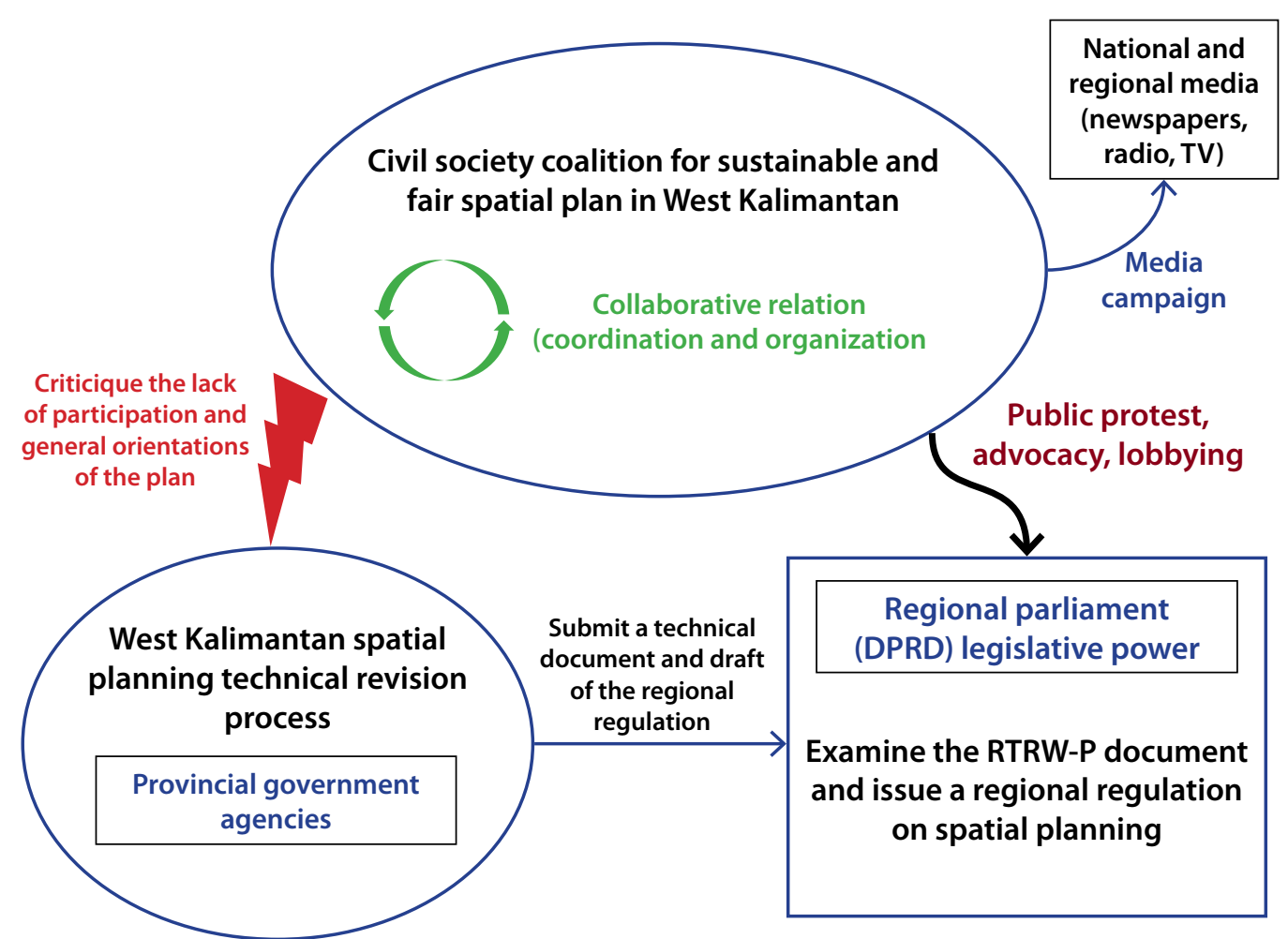

Figure 17. RTRW-P process in West Kalimantan and civil society coalition actions. 
spatial plan revision. On 26 April 2012, the most popular regional newspaper, the Pontianak Post, published two articles on the West Kalimantan spatial plan. One article was entitled: RTRW: investment vs communities' rights. It explained the position of the civil society coalition and detailed their demands to the DPRD. After the demonstration, another newspaper, the Pontianak Tribune, published an article on the civil society coalition demonstration in DPR on 30 April 2012. In May and June 2012, some Indonesian electronic media also published various articles on the issue. Some NGOs also published articles on their website.

\section{The coalition and the DPRD public consultation}

One-and-a-half months after the demonstration, the DPRD held a public consultation on RTRW-P. On 18 June 2012, the civil society coalition for sustainable and fair spatial planning in West Kalimantan was invited to participate and give its opinion about spatial planning in West Kalimantan. As a coordinator organization, Gemawan invited all the NGOs and community-based groups to join the meeting. However, only a dozen NGOs joined the public consultation (Gemawan, WALHI, PPSDAK, AMAN, LBBT, WWF, Riak Bumi, FFI, etc.). In addition, there were some university lecturers from the environment department and private consultants specialized in spatial planning. No executive government agencies were invited to this public consultation.

Through a presentation given by its chief coordinator (Gemawan), the coalition shared its diagnostic of the spatial planning situation in West Kalimantan. The diagnostic is the result of all the data collected from official sources and from partner NGOs. The major points exposed to the DPRD were (personal communication from Gemawan):

- Palm oil concessions held by 326 companies cover 4.8 million ha in West Kalimantan (33.3\% of the area).

- Mining permits held by 65 companies cover 1.5 million ha in West Kalimantan (10.4\% of the area).

- Logging concessions held by 151 companies cover 3.7 million ha in West Kalimantan (25.7\% of the area).

To sum up, the civil society coalition claimed that 529 companies have taken over 10 million ha in West Kalimantan (nearly $70 \%$ of the total area). In other words, only $30 \%$ of the West Kalimantan area is available for the 4.3 million people who live there. But, in addition, this area is also reduced by conservation and protected areas, which cover 3.7 million ha. Then, out of 14.4 million ha, only 600,000 ha $(4 \%)$ are theoretically available for the local populations of West Kalimantan. The coalition claims that because of this situation, conflict over land between communities and companies is increasing (at least 104 conflicts since 2004). In addition, using various maps, the civil society coalition exposed the following facts (Interview 9 and 47):

- Many oil palm concessions are illegal because they are partially located in the forest estate.

- The RTRW-P proposal for land designation revision favors APL.

- Hundreds villages and settlements are situated in the forest estate and protected areas.

- 'Village forests' maps made across West Kalimantan cannot be validated because of wrong non-adapted land status.

To conclude, the civil society coalition gave some basic recommendations to the DPRD based on their seven demands previously detailed.

As of September 2012, there is no evidences to show any modification of the RTRW-P orientation after the civil society coalition advocated the issue. In addition, the coalition demands seem to be wider than the simple spatial plan revision.

The recognition of communities' land rights is a national issue. It needs a national law or regulation. The coalition plays a role at the provincial scale, but it seems to be part of a larger movement.

In my opinion, their answer was quite positive. But they cannot really influence the concessions attribution because it is usually at the regency scale...

Interview 9, Gemawan

\subsubsection{Long-term involvement of community- rights defenders}

Since 1996, various NGOs have supported communities in their land-conflicts with national parks and logging or oil palm companies.

\section{Sources of land-conflicts and CSOs reaction}

During the last decades in Kapuas Hulu, many conflicts have occurred between the local communities and logging companies. More recently, the conflicts became more numerous because of oil palm concessions attributions across the regency. 
The first NGO to work on communities' land rights empowerment in Kapuas Hulu was a local NGO based in Pontianak called LBBT. At that time, the director of LBBT was from a village situated in the North of Kapuas Hulu calleed Sungai Utik. Then, called by the community which had landconflicts with two logging companies (PT Bumi Raya and PT Benua Indah), LBBT launched its first activities in Sungai Utik in 1996. Later, LBBT started to support other communities across Kapuas Hulu. It was helped by a national mass-based organization AMAN.

The first conflict adressed by these two CSOs in the 1990s and early 2000s involved logging companies and local communities. Later, the oil palm expansion in Kapuas Hulu became a growing source of conflict that these CSOs addressed as well.

Sometimes when a community has a conflict with a company, they call in some specialized CSOs for help. Often, but not always, the local pastor is the one who contacts the CSOs to explain the problem to them. Indeed, it seems that many pastors play important roles in supporting their communities to defend their land rights. However, in my personal opinion, the church as an institution is not engaged in this issue in Kapuas Hulu.

Then, if they think they can help, LBBT and/or AMAN come to the village to discuss the issue with the community. They try to understand the conflict and then arrange some meetings to advise and inform the community about their possibile options. The goal for these CSOs is to help the community to defend its customary land rights.

We work on customary rights. Usually, there are concessions which come from the government and threat the customary rights of communities. Basically, LBBT arrange the meetings and discuss with the people, talk about the laws and raise the awareness of people on their rights. We make also trainings about laws and paralegals such intimidation, etc. We give also trainings for capacity building to people.

Interview 44, LBBT

Then, depending on the situation, LBBT and AMAN (often helped by the church) support the community in various actions. For instance, in Mandalam, three times between 1997 and early 2000s, LBBT advised the community and helped them to organize public protests in the regency capital, Putussibau.
However, LBBT did not openly participate in the demonstration. Indeed, the LBBT strategy is to empower and make the people aware but never to be at the forefront of the conflict. They always avoid direct conflict with the government.

At that time in Mandalam, the communities have rejected a logging concession. Then, they have asked LBBT to facilitate and help. We have been there to discuss about the case. Then, we told to people what to do, we advise them. The strategy was to conduct a cultural demonstration in the Bupati (Head of Regency) office and in the DPRD (Regency Legislative Assembly). LBBT, together with the local church has helped to organize the people in order to conduct a strike. But for the strike, we stay behind; we were not part of the demonstration. [...] LBBT has a principle. We work for communities; our goal is to make the people themselves aware of the issues. Then, they will ask for their rights, not LBBT. We prefer to stay at the backstage.

Interview 44, LBBT

LBBT also supported the Sungai Utik community in making a public protest and complaint to the local government at the end of 1990s and early 2000s. In the same way, they organized and advised the community to conduct a public protest and ask the local government for a public hearing.

For AMAN, the situation is slightly different. As a mass-based organization with national (and even international connections), AMAN attract to communities to join their organization. Then, after the community is registered as AMAN member, they get support from the organization activists. Sometimes, like in Mandalam, the conflict case even goes up to the national level (Figure 18). Helped by AMAN West Kalimantan, AMAN national and WaIhi national, the Mandalam community expressed its views to the Ministry of Forestry in 2010.

Actually, the meeting was a negotiation between the community (supported by CSOs), the logging company and the Ministry of Forestry. However, despite a temporarily interruption of its activities, the logging company still held the concession and will continue its activities in the area.

One of the key issues in cases of conflicts between a community and a private company is the possibility of horizontal conflict among the community. Indeed, it is very rare that everyone in the community will have the same opinion about the community's 
relations with the logging or the oil palm company. According to all CSOs involved with communities in conflicts cases, the internal conflict among communities is the most difficult problem.

It is often difficult for us to organize the people because based on our experience, there are basically three groups in the community: one reject the concession, one accept it and the third one is between the two other. Thus, the most difficult thing is when there is a horizontal conflict between people of the community. Furthermore, the horizontal conflict is often exploited, envenomed by other people behind, in the backside... The ones who take the profit always avoid the community unity. [...] Even inside a family, there are sometimes horizontal conflicts... For instance, in Embaloh Hulu, while a large part of the communities reject oil palm, some elites in the villages accept it because they have connection with the companies.

Interview 44, LBBT

\section{Community mapping for customary land rights}

PPSDAK is a local NGO specialized in community mapping and spatial issues. Founded in Pontianak in 1994, they started their mapping activities in Kapuas Hulu in 1998. Then, up to 2012, they have mapped 35 sub-villages (kampung) in 16 villages (desa) and six districts of Kapuas Hulu (Interview 50 and 51, PPSDAK). The total area already mapped in Kapuas
Hulu represents between 500,000 and 550,000 ha ( $17 \%$ to $21 \%$ of Kapuas Hulu area). The smallest area mapped for a sub-village is 1,150 ha (Apan) and the largest area for a sub-village is about 167,102 ha (Mandalam).

PPSDAK argues that the maps have three major positive impacts for communities (Interview 51, PPSDAK):

- They can contribute to enforce and protect communities' customary land rights.

- They can help the communities to know their territory better and to improve their land-use planning.

- They can be used by communities as a tool to control the potential investments coming into their area.

The community mapping is a participative process, which produces a simple map including village territory limits and general land-uses. This map can be used by communities to show the government and/or companies the area where they claim customary land rights. While the government hardly recognizes customary land rights and has never mapped these community lands, this tool is the only one available for communities to show the limits of their village lands. The map can also be used by the community to improve land-use planning. Finally, if a company gets a concession which overlaps their lands, the community can use the map to show the

First activity of LBBT in

Kapuas Hulu (Sungai Utik) -

logging concession conflict

First LBBT support to

Mandalam community -

logging concession conflict

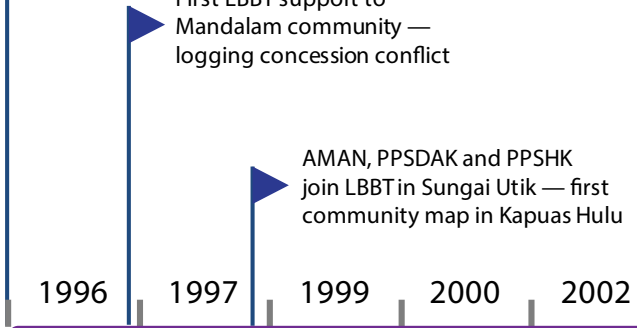

Second LBBT support to

Mandalam community -

logging concession conflict

Tripartite negociations

AMAN/Ministry of Forestry/logging

compagny on Mandalam conflict case

PPSDAK has mapped more

than 500,000 ha of community

territories

MoU AMAN — regency land agency (BPN) on BRWA

First workshop of

large-scale community

mapping project 
company the boundaries of their territory. Then, the community can reject the company or engage negotiations in order to get benefits or compensations from the company.

PPSDAK makes participative maps with communities if they ask for it. Actually, there are two situations where PPSDAK will support a community with participative mapping (PPSDAK, 51):

- The community asks PPSDAK to facilitate the mapping process of their territory. Usually, they send a letter to the PPSDAK office in Pontianak or come directly to the office and ask for support.

- A partner NGO, which has worked with a community, asks PPSDAK to make a participative map for the village. In Kapuas Hulu, these partner NGOs have usually been LBBT and AMAN. The mapping process is then often linked to land-conflict situations when the community wants to secure its land rights.

When the community map is completed, there are two copies available: one for the community and one for PPSDAK. While the community can use the map as they want, PPSDAK has specific rules for using and sharing the maps. Actually, according to their agreement with the community, the map belongs to the villagers. Thus, PPSDAK never shares the map with anyone without the agreement of the community. In practice, since 1998 in Kapuas Hulu, PPSDAK has kept the maps and has not shared them with other stakeholders (governments, NGOs, etc.). For instance, while PPSDAK has mapped 35 sub-village territories in Kapuas Hulu, the local government agencies do not have any copies of these maps. The mapped community territories represent more than 500,000 ha in Kapuas Hulu, but none of the local agencies such as the forestry agency, land department, BAPPEDA or BPMD have information about these maps.

For sharing data, we have a mechanism, rules. According to our internal rules, we cannot give the data to the government. For that, we need the agreement, a permit from the communities. Then, no people can take the maps if there is no validation from the community. We never share the original map. We only share the parts that we think can be seen by the government.[...] It is based on our agreement with communities... Interview 50, PPSDAK

Thus, because PPSDAK has never shared their villages' maps with the local government, other
NGOs criticize their non-collaborative strategy. Because they refuse to collaborate with the government and share their data, PPSDAK have chosen an inefficient strategy about community land rights recognition:

... [about PPSDAK] They have a wide experience in covering community mapping in some areas in Kapuas Hulu. But, the results, the participative maps are only kept for them. [...] They didn't share the results, the documents, the maps with the government agencies, with the local parliament... [...] They say "it is a part of our protection. We cannot share the result to other parties." But our position is different. Then, we criticize this strategy. Who knows? The government doesn't know, the private sector doesn't know about what kinds of land are around the village, what kind of customary uses and status... They cannot know if you have not shared with other parties. So, that is why we criticize their strategy [the strategy of PPSDAK]. Now I heard they start to change their strategy, they start to share documents with the government.

Anonymous

It seems that PPSDAK has recently started to change its strategy. Although nothing has changed in Kapuas Hulu for the moment, a new mechanism of customary land rights registration (BRWA) exists. PPSDAK is the coordinator of this registration system in West Kalimantan (Interview 51, PPSDAK). Then, PPSDAK will obviously share its data and community maps.

\section{BRWA, a paralegal customary land rights registration system}

The Ancestral Domain Registration Agency (Badan Registrasi Wilayah Adat, BRWA) is a national institution that was founded in 2010 by three national CSOs: AMAN, JKPP and FWI. BRWA is a paralegal land rights registration system developed to support the efforts undertaken by many communities and NGOs to map the customary territories across Indonesia. The objective of BRWA is to register and centralize data about communities' ancestral domains all over Indonesia (Interview 51, PPSDAK). It aims to contribute to customary land rights recognition in Indonesian. The database is useful for government, the private sector and NGOs to check the existence of customary land rights. The BRWA coordination board at the national level is based in Bogor. Registration offices have been opened in 
collaboration with partner NGOs at the provincial and regency levels.

\section{In West Kalimantan, AMAN-KalBar and PPSDAK coordinate the BRWA at the provincial scale. BRWA was initiated at the provincial scale by AMAN-KalBar in October 2011 (Interview 45, AMAN). But, in fact, BRWA in West Kalimantan is coordinated by PPSDAK and funded by the Samdana Institute. In addition, LBBT participate in the process as a verification organization. In West Kalimantan, including Kapuas Hulu, the first objective of these NGOs is to register the areas mapped by PPSDAK and a few other NGOs. In Kapuas Hulu the 500,000 to 550,000 ha of customary lands already mapped by PPSDAK will be registered under the BRWA system.}

To enforce the recognition of BRWA by the government in West Kalimantan, AMAN-KalBar signed an $\mathrm{MoU}$ with the provincial land agency (BPN) in June 2012 (Interview 45, AMAN; Secondary data: $\mathrm{MoU})$. Through this $\mathrm{MoU}$, both parties agree to collaborate and share information and data in order to promote indigenous community-rights and respect of laws. However, in Kapuas Hulu, BRWA is not known by the BPN and the authorities yet.

Following the national rules for registration, PPSDAK use a registration form for customary territories registration under BRWA. A simple form is given to communities; they fill it in and return it to BRWA office in PPSDAK. Then, data are verified by BRWA office in Pontianak and then verified a second time by LBBT (Interview 51, PPSDAK). In Kapuas Hulu, only four BRWA registration forms, representing an area of 147000 ha have been completed since the end of 2011. However, only one village has been verified and integrated into the national database: Sungai Utik. Actually, the NGO in charge of BRWA in Kapuas Hulu is Lanting Borneo. But they have not started to work on it. Their plan is to focus on the 35 villages already mapped by PPSDAK.

In Kapus Hulu, the organization in charge of BRWA is Lanting Borneo. But we have not started to work yet. We will start in July 2012. Actually, the objective of BRWA in Kapuas Hulu is to register villages customary territories in order send it to BPN and ask for their official recognition. We will use the maps already made by PPSDAK in 35 sub-villages (kampung).

\section{Sungai Utik village, certification of customary forest}

In 2004, the EU launched a project entitled,

"Promotion of Ecologically Sustainable, Socially Equitable and Economically Viable Forest Management in Indonesia through Implementation of Credible Certification Systems". The EU financially supported three national NGOs (LEI, AMAN and FWI) to conduct the project in the field. Out of three pilot sites in Indonesia, Sungai Utik, a small village in the north of Kapuas Hulu was chosen, on the suggestion of AMAN-KalBar, who had already worked with this community (Interview 57, LEI). Sungai Utik was chosen because the villagers wanted to protect their customary forest against logging and all external investments (Interview 45, AMAN).

While other regional NGOs specialized in communities' land rights (LBBT, AMAN, PPSDAK, PPSHK) had worked in Sungai Utik since 1996, $\mathrm{LEI}^{19}$ and started to work intensively in the village in 2005. LEI collected various data from NGOs in order to prepare the certification. Thanks to a successful collaboration between regional NGOs and national NGOs, LEI compiled data on the Sungai Utik's customary forest and its management (Interview 57, LEI).

In order to get the certification, LEI and AMAN had tripartite negotiations with the Ministry of Forestry and two logging companies, which hold concessions overlapping the Sungai Utik territory. Finally, the companies verbally agreed to leave the overlapping areas within the Sungai Utik territory. But the real situation is not clear yet.

Finally on 22 March 2008, LEI gave Sungai Utik a registration certificate for its sustainable communitybased forest management for an area of 9,453.4 ha. The certification is valid for 15 years until March 2023. However, the certificate has not been legally recognized by the Indonesian Government. After the Ministry of Forestry visit to Sungai Utik on 7 August 2008 for the LEI certification ceremony, nothing else happened for Sungai Utik. The village still does not have any legal rights over its customary forest.

19 LEI is an Indonesian NGO specialized in delivering forest certification in order to promote sustainable management and good forest governance in Indonesia. LEI delivers independent certificates that certify the sustainability of forest management in various contexts (production natural forests, plantations forests and community-based forests). 
[...] the 7th of August 2008, the day that the Ministry of Forestry came for the certification ceremony of Sungai Utik's forest. There were also people from AMAN National, LEI and various other national and regional NGOs. That was a big celebration! And the ministry of forestry said that the world should learn sustainable forest management from the customary people of Sungai Utik. But until now, despite its promises, there is no regulation, no recognition of their land rights. Actually, for customary land rights recognition, we need a National law (undangundang), it is not a local issue...

\section{Interview 3, AMAN}

\subsubsection{Community-based forest management facilitation: "village forests" mechanism} In 2008, the Ministry of Forestry passed Regulation P49/2008 on village forests (butan desa). The international NGO FFI launched its village forest facilitation program all over Indonesia. Its first activities on hutan desa in Kapuas Hulu started in early 2010 (Interview 20, FFI) (Figure 19). The objective of FFI was to facilitate the development of village forests in Kapuas Hulu. FFI conducted both a lobbying process with the local forestry agency and a promotion and facilitation process with communities. Indeed, they tried to convince the local forestry agency to support village forests initiatives and approached communities to promote the village forest scheme and proposed to facilitate the application process (Interview 20, FFI).

\section{Why village forests (hutan desa)?}

FFI supported the idea of community-based forest management rights at the national level in the 2000s. They conducted intense lobbying at the Ministry of Forestry during the elaboration of the regulation on village forests (PP 49/2008) (Interview 29, FFI). Then, after the issuance of the law in 2008, FFI started to support village forests initiatives across the country. Village forests are an opportunity for FFI to promote conservation issues and enhance local communities' livelihoods. FFI promote village forests in order to support a sustainable and community forest management system, including conservation and local livelihoods objectives.

FFI was actively involved in the government regulation about hutan desa (2008). In our opinion, hutan desa is the only scheme, which gives real management rights to people and contribute to sustainable use of forests [...] The idea to support hutan desa has been chosen

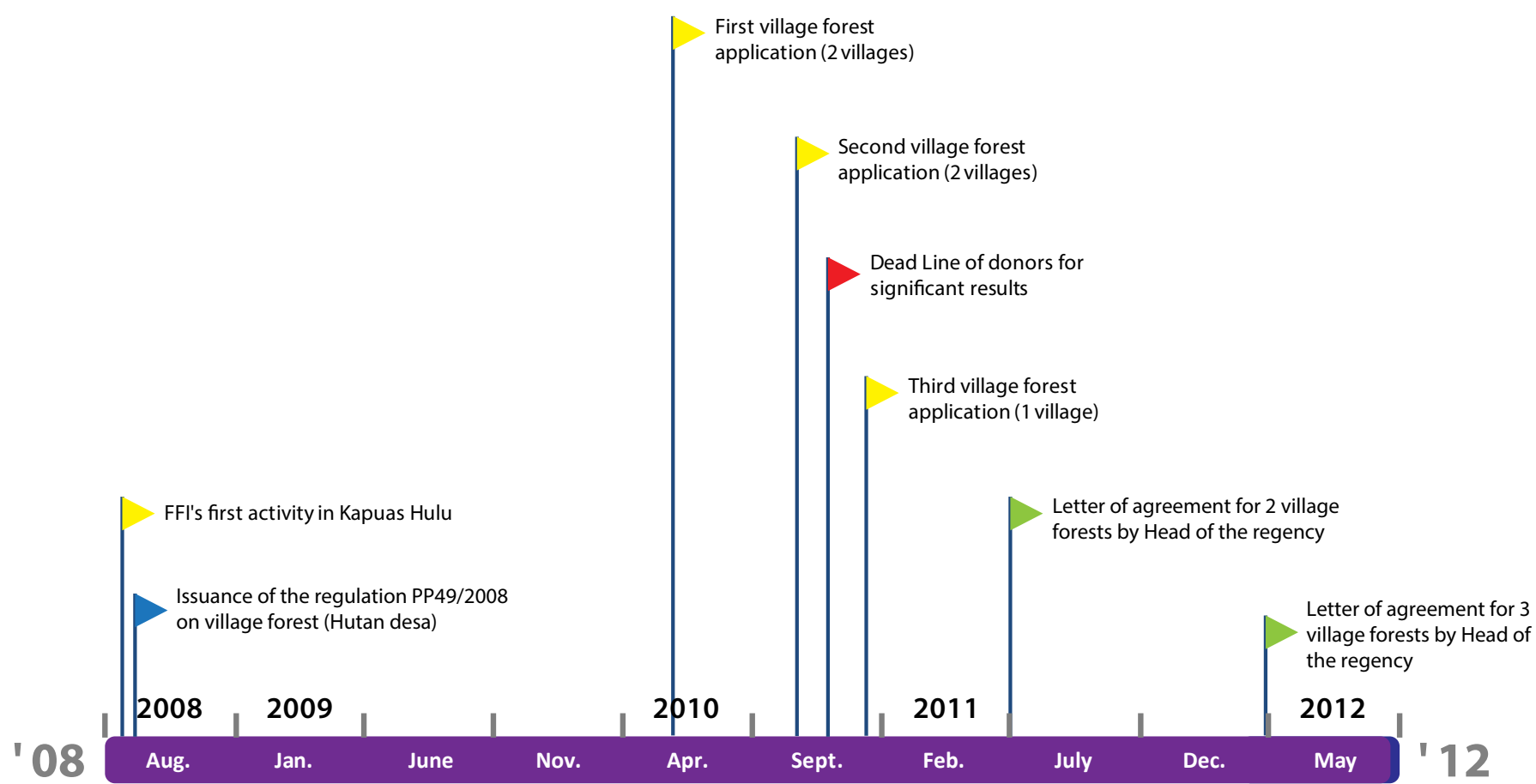

FFI's project in Kapuas Hulu for village forest (hutan desa) faclitation

Figure 19. FFI actions on village forest issues 2008-2012. 
by FFI in Jakarta. The thing is that hutan desa gives the opportunity to FFI to achieve its goals of ecosystems conservation in respect with communities' livelihoods issues. hutan desa is also a good opportunity for FFI to change the paradigm of government and communities about forest. The forest is not only products, it has to be managed sustainably in order to give livelihoods to people and contribute to conservation issues.

Interview 29, FFI

FFI aims to develop 'community carbon pools' for conservation projects based on the carbon market. While the first step is to get legal 'village forests' licenses for villages, the second step will be to propose REDD+ projects to these villages under the 'community carbon pools' mechanism. In fact, it seems that FFI plans to use village forests as a tool for reducing deforestation and forest degradation, to reduce greenhouse gas emissions. It would be through a potential international agreement on REDD+ mechanisms or in the voluntary market. FFI has a collaboration framework at the national level with the Ministry of Forestry but also thinks about voluntary standards such VCS, CCBA and Plan Vivo

Interview 29, FFI.

With Community Carbon Pools (CCP), you can integrate several villages under one Project Design Document (PDD) for REDD project. [...] I am also thinking that the CCP for villages can become part of the Indonesian government preach to reach the target of $26 \%$ of $\mathrm{CO}^{2}$ emission reduction. [...] Then, in order to achieve this target, the government should give an incentive to these CCP villages. Thus, FFI is doing lobbying in Jakarta. It is our first target for CCP. But we also have a plan B if the government disagrees with this idea. We will work by our own under VCS and CCBA voluntary market standards.

Interview 29, FFI

\section{Field facilitation process}

The 'village forests' FFI's assessment process is divided into three steps (Figure 20):

- First, FFI meets the head of the village and its secretary. They give them some copies of Regulation P49 on village forests and try to explain the principles and benefits of the mechanism to them. The FFI allows the village authorities to explain to the villagers what a 'village forest' (butan desa) is and asks them if they are interested. Thus, if there is an interest in the community,, the head of the village will call FFI for a second visit.

- For the second visit, the FFI meet with all of the community. They organize an open meeting and explain to the village the regulation and the benefits of village forests. They answer the questions and explain the application procedure and the process of getting the 'village forest' certificate. Then, if the village is interested, FFI asks them to write a commitment that certifies the general interest for a 'village forest' among the community. FFI also ask the villagers to think about the social and economic potential of their forest, to start to collect data on their forest resources and to list the potential benefits of village forests for them.

- Then, the third FFI visit is dedicated to writing and finalizing the formal village forest application that will be sent to the local forestry agency and then to six other authorities. Actually, the villagers write the first draft of the proposal and FFI help them to improve their application document. For instance, FFI conduct participative mapping to design comprehensive maps with the limits of the village forest. At the end, the village sends its proposal to the local forestry agency.

Since 2010, FFI has approached 32 villages in Kapuas Hulu to present them with the 'village forest' regulation. A total of 18 out of 32 villages showed a positive attitude to village forests and expressed interest in the idea. But since 2010, only five villages have submitted a formal proposal to the forestry agency. Two of them got the authorization from the head of the regency (bupati) in July 2011 and the others received approval in April 2012. Recently, a further four villages have contacted FFI for help to prepare their village forest applications.

\section{Contract-based collaboration with regional and local NGOs}

FFI staff rarely visit the villages for facilitation processes except on special occasions. In general, FFI plays the role of coordinator and project leader. But for fieldwork, FFI collaborates with local and regional NGOs. Since 2010, FFI has signed contracts with one local NGO, two regional NGOs and one independent consultant (former director of a regional NGO). These local and regional NGOs aim to assess the potential of 'village forests', to approach villages, to promote the village forest mechanism and to 
facilitate the field process. Each NGO signs shortterm contracts with FFI for a specific mission.

Actually, rather than hire and train field staff, FFI has chosen to outsource the fieldwork, particularly the aspect of socialization and interaction with communities. As an international NGO specialized in biodiversity and conservation, FFI has chosen a strategy of intense collaboration with local and regional NGOs for social aspects. These NGOs are able to establish positive contacts with communities.

The main core of FFI is biodiversity. For social issues and relations with communities, FFI does not have good capacities. Then, for social process under the village forest project, we collaborate with local NGOs. The local NGOs are more able to work with communities and to build the relationship.

Interview 20, FFI
Kaban has a partnership with FFI to build the dialogue with communities. Kaban is the gobetween that connects the people and FFI. We facilitate the dialogue.

Interview 4, Kaban

In collaboration with FFI, we are facilitating CBFM [Community-based forestry management] in Kapuas Hulu. PRCF staff work in the field, in the villages with communities. FFI is more involved in administrative things. They facilitate the legal aspects, the formal documents, etc. FFI goes to the field only for monitoring, not with technicians. Actually, we signed a MoU with FFI about hutan desa which defines our roles, our duties, the conditions, the payment price and conditions... FFI finance this project.

Interview 6, PRCF

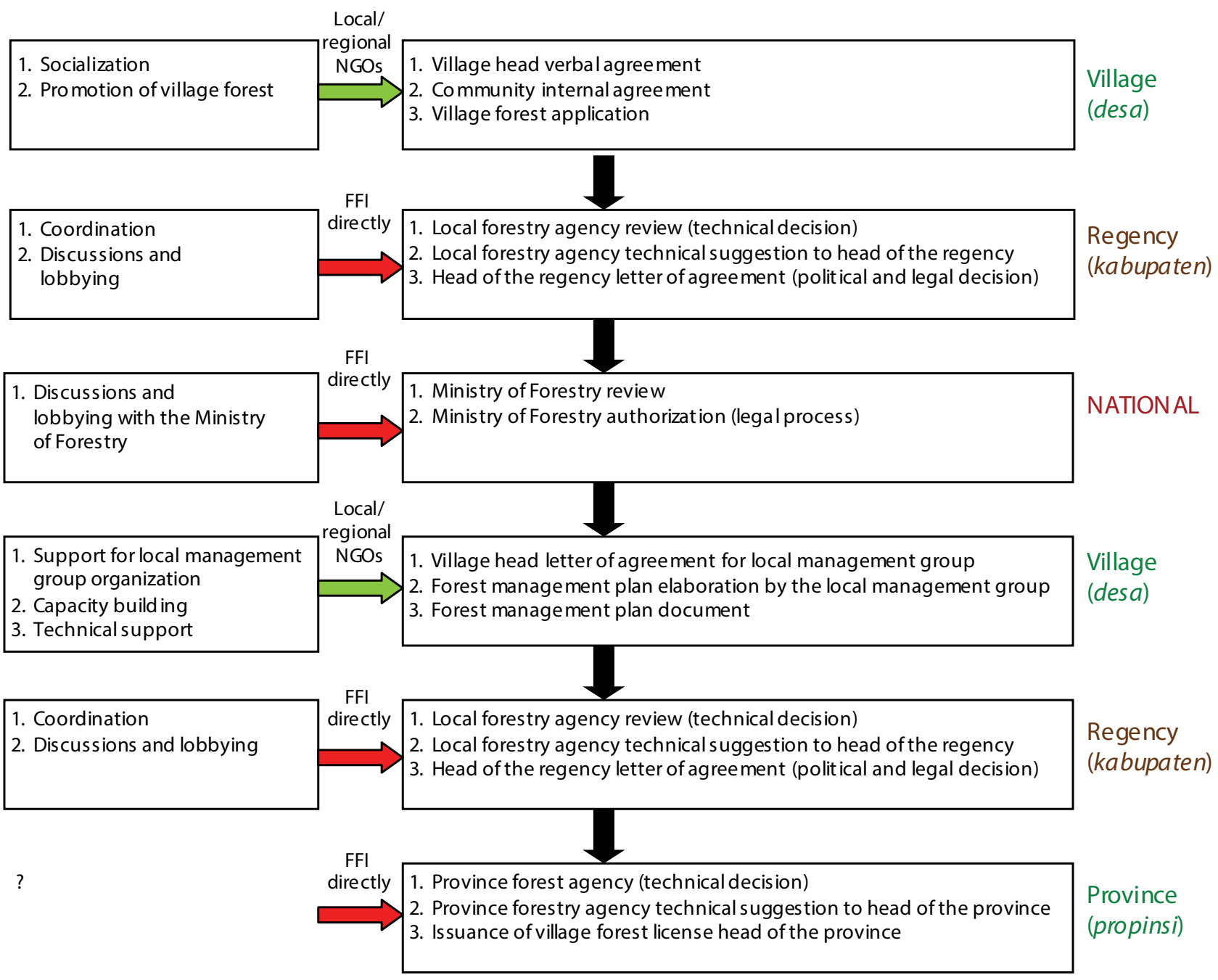

Figure 20. Hutan desa validation mechanism and FFI influence. 
This kind of collaboration between FFI and local NGOs is very formal. The duties and tasks of each actor and the terms of their collaboration are formalized by a contract. In this situation, FFI act both as a donor and as a project leader. Local NGOs work as service-providers and go-betweens for communities affected by FFI projects.

\section{Administrative process and relations with the government}

As a legal mechanism, village forests need multilevel agreements from the regency, national and provincial government. FFI can support the idea and encourage the communities to apply for village forests but the decision-making power is held by various government stakeholders (Figure 20 and 21). At the regency scale, it needs a validation from the head of the regency (bupati) who is advised by the forestry agency. Thus, in Kapuas Hulu, FFI mainly interact with the local forestry agency (Interview 20, FFI; Interview 16 , forestry agency).

We have to coordinate with dinas kehutanan in order to reach our objectives for hutan desa.

Interview 20, FFI
The FFI regency program coordinator has close and frequent collaboration with the head of the rehabilitation and social forestry division. However, the technical and administrative process at the regency scale seems to be long and difficult for FFI. According to an informant, the local forestry agency was traumatized by a previous mechanism of smallscale forestry in the 2000s. After the widespread illegal logging activities following the issuance of many HPHH permits in the early 2000s, the local forestry agency seems today to be very cautious with village forests.

Before hutan desa, there were something similar which was named HPHH (100 ha small-scale concessions). It was from 1999 to 2003 or 2005. $\mathrm{HPHH}$ were out of control and contributed to make people involved in illegal and anarchic logging in Kapuas Hulu. [...] The first idea of $\mathrm{HPH}$ was to make local people producing their own timber to improve their livelihoods. But then, it was misused by people... Thus, dinas kehutanan has been traumatized by small-scale forestry and was afraid that hutan desa conducts

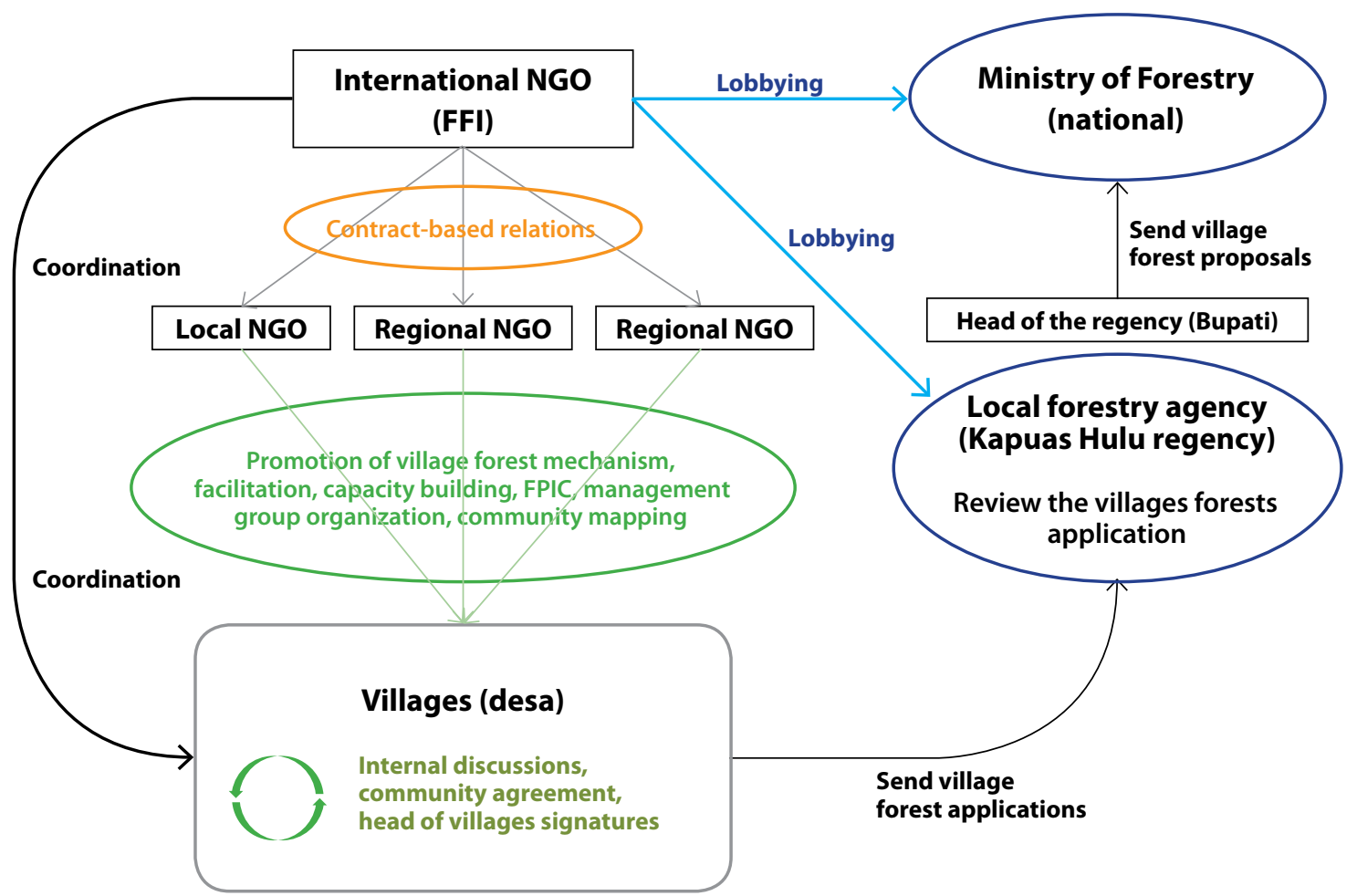

Figure 21. Tree of interactions on hutan desa issue in Kapuas Hulu. 
to the same anarchy with HPH before... That is why it is quite difficult to make hutan desa.

Anonymous

You know, I am tired ... Sometimes I feel very sad ... Here in Kapuas Hulu, it is so hard to work $[\ldots]$ with the government. For villages' forests, I feel shame... We already have started two years ago in 2010. [...] In the forestry agency, they are not motivated for that. Except Mr. XX who tries to push the process, the other do not want to take risks. For example Mr. YY, he tried to slow down the process. He doesn't care about the communities ...

Interview 20, FFI

Because of the delay in the village forest project, FFI has even lost funds, after two donors temporarily cancelled their support to village forest FFI initiative in Kapuas Hulu.

Because of the delay, we have lost 800 million IRP (80,000 US\$) from ARCUS and 400 million from UE. For them, the proposals should reach the Ministry of Forestry in December $2010 \ldots$ The donors ask for results and if there are not, they do not give more funds.

Interview 53, FFI

Thus, despite some progress, the outcomes for FFI are far from what were expected.

\subsection{CSOs action strategies comparative analysis}

\subsubsection{CSOs strategies on LUP: soft participation vs advocacy coalition}

In Indonesia, official land-use planning is regulated by Law No. 26/2007. The RTRW-P and the RTRW-K were revised under this law at the same time in 2010. Since the technical processes ended, both spatial plans are currently awaiting legal validation. The West Kalimantan spatial plan should be validated by the DPRP through a regional regulation (perda). The Kapuas Hulu spatial plan should be validated by the DPRK through a local regulation (raperda). While these processes have been conducted simultaneously, it appears that CSOs have chosen two different action strategies to influence LUP.

- Few international NGOs actively participated in the spatial planning revision process in Kapuas Hulu in 2010.
- A large civil society organizations coalition is challenging the West Kalimantan spatial plan since 2011 .

We propose here a comparative analysis of these two strategic approaches in regard to their objectives, collaborative strategies and relations with the government.

\section{Limited 'conservationists' participation vs large and diversified coalition}

In Kapuas Hulu regency, only three international CSOs participated in the spatial plan revision technical process. The two most active ones during the process were well-known international conservation NGOs. Their objectives were clearly set on biodiversity and habitats conservation. However, despite similar general objectives, each CSO had its own specific objectives. It appears that they did not strictly coordinate their actions and arguments in a collaborative way. While they sometimes defended the same issues, it was linked to their common conservationist approach. These CSOs did not specifically share the tasks in a collaborative and synchronized approach. This is a result of the 'competition' that may exist between international conservation NGOs or because of the differences between the projects of these CSOs. The small number of CSOs involved and the individualism shown during the participative process did not lead to a strong collaborative strategy. Moreover, participation of other CSOs such as local and regional NGOs during the public consultations was weak or almost nonexistent. Most of them openly criticized the lack of public participation during the process and the spatial plan produced. Particularly, CSOs interested in community land rights issues strongly criticized the spatial planning process and the lack of participation of civil society. Therefore, the three CSOs who have participated in the process do not represent the whole CSO community in Kapuas Hulu. For instance, while international NGOs are satisfied to have been involved, community-rights defenders criticize the lack of participation during the process.

In contrast, the civil society coalition for a sustainable and fair spatial plan in West Kalimantan is composed of at least 40 CSOs, which includes local, regional, national and international CSOs (Table 3). These CSOs are mainly NGOs but a mass-based organization and various community groups are also involved in the coalition. The diversity of CSOs results in a large range of objectives for the coalition. 
It is coordinated by a regional $\mathrm{NGO}$ who is in charge of the organization and coherence of the coalition. The coalition is not strictly and hierarchically organized but it includes a multilevel actions and tasks division. For instance, while some CSOs are passive, others provide data and information, others are active in the media (newspapers, Internet), advocacy among local communities, public protests and/or lobbying. Their strategies and actions are decided in common during semi-formal meetings and through consensus-based decisions. The regional NGO Gemawan aims to articulate and coordinate the strategies and actions decided with its partners.

The contrast is clear between the two situations in terms of representativeness, legitimacy, CSOs diversity and range of general objectives which are directly linked to participation rules and constraints (Table 4). Indeed, while participation in the Kapuas Hulu spatial plan revision process was limited and decided by the local government, participation to the civil society coalition is open and encouraged. In one case, CSOs participation depends on government decision and in the other case CSOs' participation is voluntary, free and unrestricted.

In addition, logistic and financial constraints for CSOs' participation are different. In Kapuas Hulu, invitations for public consultations were individually given to few NGOs. Their potential participation was limited in time and space. If they wanted to participate, they had to be present in Putussibau on the day of official public consultation. While most of the NGOs invited were based in Pontianak, which is an 18-hour journey by car from Putussibau, the logistic and financial constraints were very high for them. In contrast, while the coalition coordination is based in Pontianak, most of the CSOs involved do not have difficulties in joining the meetings and/or specific actions. Indeed, except for local community-based groups, most of the NGOs in West Kalimantan have their office in Pontianak. This might explain why no coalition has been founded at the regency scale and why most of the coalitions in West Kalimantan occur at the regency scale.

It seems that for local and regional CSOs, participating in a civil society coalition is easier than participating in governmental decisionmaking process. Thus, the civil society coalition for sustainable and fair spatial planning in West Kalimantan is more diversified in terms of CSOs and objectives. When we examine the whole CSOs landscape in West Kalimantan, the coalition appears more representative and legitimate than the few CSOs who participated in the Kapuas Hulu spatial plan revision process. But the situations are different and the strategies used are not the same. In other words, the choice of a soft approach or a hard approach may influence the way that CSOs collaborate and organize their interrelations.

\section{Soft approach vs hard approach}

It is clear that the participation of a few CSOs in the decision-making process in Kapuas Hulu, and the CSOs advocacy coalition in West Kalimantan, do not follow the same logic in term of strategies of interaction with the government. Actually, CSOs participation in Kapuas Hulu took place during the political and technical decisionmaking process coordinated by a local government agency (BAPPEDA). The CSOs involved were parts of the revision mechanism. In contrast, the coalition came about in West Kalimantan because

Table 3. Comparison of participative process in Kapuas Hulu and civil society coalition in West Kalimantan.

\begin{tabular}{lll}
\hline & $\begin{array}{l}\text { Participation to Kapuas Hulu spatial } \\
\text { planning revision process }\end{array}$ & $\begin{array}{l}\text { Civil society coalition for sustainable and } \\
\text { fair spatial planning in West Kalimantan }\end{array}$ \\
\hline Year & 2010 & $2011-2012$ \\
Scale & regency & province \\
Number of CSOs involved & 3 & $40+$ \\
Types of CSOs & International & Local, regional, national and international \\
Coordinator & No coordinator & Regional NGO \\
Coordination meetings & No & Yes \\
General objectives & Biodiversity and habitats & Socioenvironmental justice, conservation, \\
& conservation & communities' land rights recognition, good \\
& & governance, civil society participation
\end{tabular}


Table 4. CSOs participation vs civil society coalition.

\begin{tabular}{lll}
\hline & $\begin{array}{l}\text { Participation } \\
\text { in Kapuas Hulu } \\
\text { spatial planning } \\
\text { revision process }\end{array}$ & $\begin{array}{l}\text { Civil society } \\
\text { coalition for } \\
\text { sustainable } \\
\text { and fair spatial } \\
\text { planning in West } \\
\text { Kalimantan }\end{array}$ \\
\hline $\begin{array}{l}\text { Rules of CSOs' } \\
\text { involvement }\end{array}$ & $\begin{array}{l}\text { Decided by the } \\
\text { local government }\end{array}$ & Free participation \\
$\begin{array}{l}\text { Participation } \\
\text { constraints }\end{array}$ & High & Low \\
$\begin{array}{l}\text { Number and } \\
\text { diversity of } \\
\text { CSOs }\end{array}$ & Low & High \\
$\begin{array}{l}\text { Diversity } \\
\text { of CSOs } \\
\text { objectives }\end{array}$ & Low & High \\
$\begin{array}{l}\text { General } \\
\text { representation } \\
\text { of the CSOs' } \\
\text { community }\end{array}$ & Low & High \\
\hline
\end{tabular}

of the disappointment of several CSOs over the political and technical decision-making process for the West Kalimantan spatial plan. It was founded because CSOs and communities were not allowed to participate properly in the spatial plan revision process.

Thus, it results in two different types of relationship with the government. The three international CSOs invited to participate to the Kapuas Hulu spatial plan revision process had already established fairly good relations with the local government. Before being invited by BAPPEDA to participate in the spatial plan revision, they already had formal and informal collaboration frameworks with local government agencies. In particular, they had all interacted with BAPPEDA, which was in charge of spatial planning at the regency scale. These CSOs avoided direct confrontation with the local government and found allies among civil servants. They preferred a diplomatic and consensual approach. These international CSOs had data which were potentially useful for land-use planning. They were also reputed to have competent and skilled staff notably in GIS and spatial planning issues. Thus, the lack of confrontational relations with the local government (and particularly with BAPPEDA) and association with good data, knowledge and skills on spatial planning influenced BAPPEDA to invite these CSOs to participate. Later, during the decision-making process, these CSOs had more tense relations with government, particularly with the forestry and plantations agency. But it was a situation of lobbying and negotiations. The oil palm expansion issue and the protection of the Danau Sentarum National Park buffer zone were the most sensitive issues between the $\mathrm{CSO}$ and the local government. The conservation paradigm was heavily criticized by the plantation agency, which prioritized economic development needs. In return, NGOs point out the negative aspects of the oil palm sector.

In contrast, the coalition criticizes the fact that the provincial government did not involve civil society during the decision-making process (Table 5). In fact, this civil society collective movement comes from the failure of the provincial public work agency and forestry agency to involve CSOs in a participative process on spatial planning. In fact, they used what Torrow (2011) calls "contentious politics," which "often is the only recourse that ordinary people possess against better-equipped opponents or powerful states". Thus, the coalition is openly critical of the provincial government and its executive agencies. The RTRW-P produced in 2010 has been denounced by the coalition. It criticizes the lack of participation during the process, the Socioenvironmental impacts of the plan and the absence of recognition of communities' land rights. The coalition does not want to discuss with regency sectoral agencies but targets the legislative power through the DPRP. Their logic is to avoid the issuance of a regional regulation on spatial planning which would be unfair and unsustainable. Because members of the regional parliament are elected by citizens, the coalition wants to pressure them through a collective and large-scale civil society movement. To reach its objectives, the advocacy coalition has used public protest (strong approach) and a media campaign and lobbying (soft approach). In other words, they forced the regional parliament to hear them, thanks to collective protests in the streets and the media. Then the coalition presented its logic and arguments to the regional parliament.

The double strategy of an international NGO (WWF) is interesting to study. Indeed, while this NGO was a member of the technical team that coordinated the Kapuas Hulu spatial plan revision, it also joined the advocacy coalition on spatial planning in West Kalimantan. Thus, it appears that this international NGO plays a complex and multilevel strategy to reach its objectives. WWF mixes a nonconfrontational and collaborative approach with the 
regency government, with a challenging and critical approach at the provincial scale. However, they do not take a foreground position in the advocacy activities of the coalition. They prefer to keep a background position and share their data and good technical skills with others.

\section{Outcomes comparison}

For the three CSOs who participated in the Kapuas Hulu spatial planning process, the result is intermediate. On one hand, some land-use status changes seem positive for peat swamp conservation. The designation of an ecotourism strategic area and an ecological corridor strategic area are also good news for conservationist NGOs. On the other hand, the new land-use planning map proposed at the end of the revision process allocates more space for nonforest uses (including oil palm plantations). This expansion also negatively impacts on DSNP buffer zone, which is severely restricted. Globally, even the APL have increased by $63 \%$, so the conservationist CSOs are satisfied by the situation. Indeed, $52.8 \%$ of the total Kapuas Hulu area remains under conservation land function status (conservation forests and national parks).

But for other CSOs which have not been actively involved in the decision-making process, the new Kapuas Hulu spatial plan does not address the local communities' needs in terms of customary land rights recognition and sustainable livelihoods sources.
These regional and local NGOs criticize the lack of participation during the process and the result, but have not used concrete actions to refuse or influence the issuance of the local regulation on Kapuas Hulu spatial plan.

For the moment, the coalition for a sustainable and fair West Kalimantan spatial plan has not received evident results. Their media campaign and the public protest organized in April 2012 forced the regional parliament to hear the coalition demands. That was the first step. Then, the commission in charge of spatial plan regional regulation gave them a verbal agreement for examining the coalition demands and arguments. The coalition was invited to expose its demands and arguments to the regional parliament in June 2012. Therefore, the regional parliament will organize a workshop and will invite the coalition to expose some specific and detailed cases. But up to now, there is no evidence that the coalition will get significant results. The regional parliament has not yet issued the regional regulation; the process is still ongoing.

\subsubsection{CSOs roles on communities land rights and their strategies}

In Indonesia, because of unclear and contradictory regulations, customary land rights are not recognized. In Kapuas Hulu for instance, it means that most of the local communities have de facto land rights but not de jure rights. Their tenure security (including

Table 5. Comparison of CSOs' relations with government.

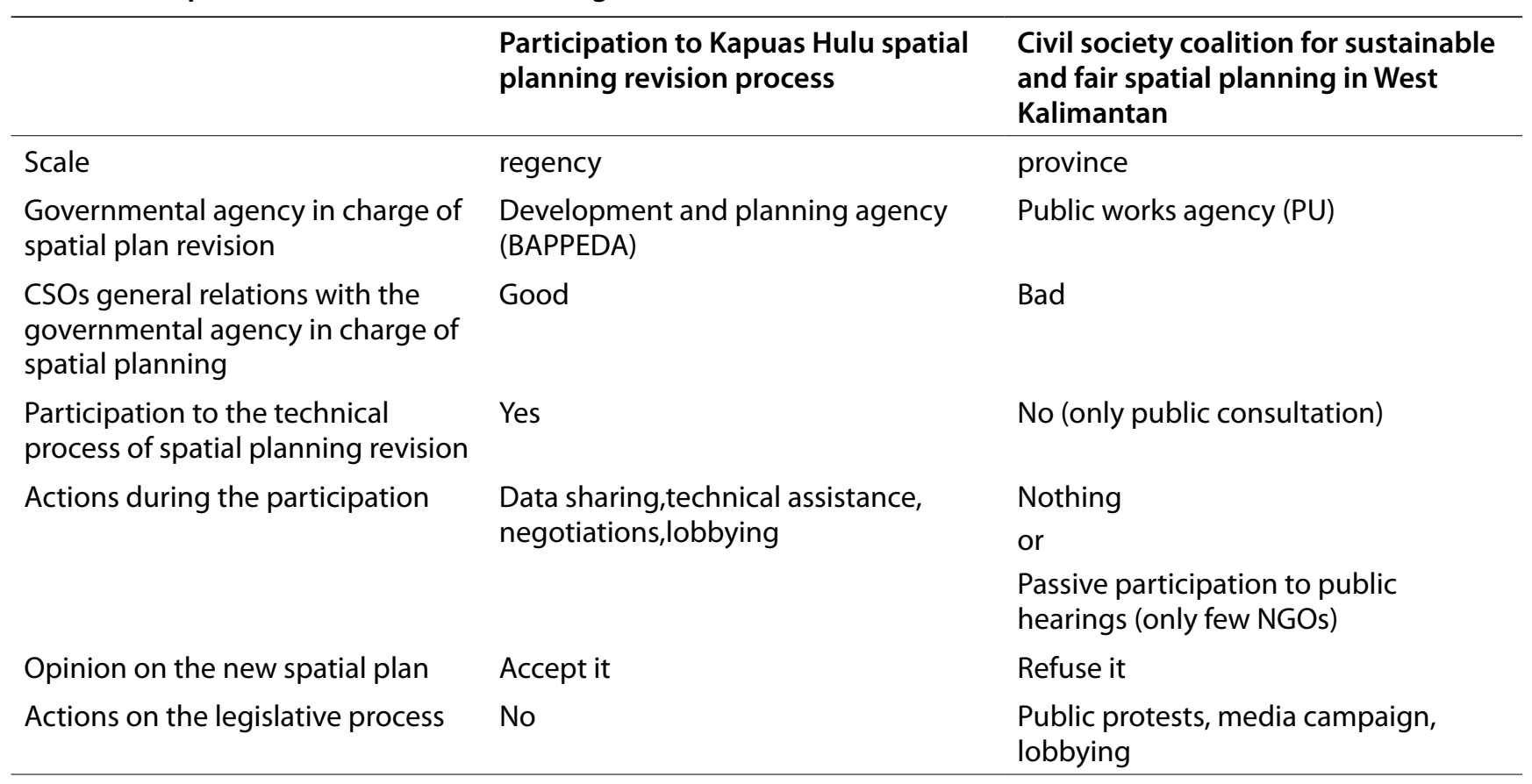


access to the resource security) is weak and often threatened by potential private investments such as logging and oil palm concessions.

In Kapuas Hulu, I identified two major CSO approaches. On one hand, some local, regional and national CSOs carry out a variety of activities in order to help local communities to defend their customary land rights. On the other hand, an international NGO (working with local and regional NGOs) promotes a legal community-based forest management mechanism called hutan desa. In the first case, there is no clear regulation that guarantees the customary land rights recognition by the government. In the second case the hutan desa mechanism is regulated by Law PP 49/2008 issued in 2008 .

\section{Resources access right vs land rights}

Since 1996, CSOs have defended communities' land rights in Kapuas Hulu (and all over West Kalimantan). Historically, these regionally implemented CSOs (AMAN, LBBT, PPSDAK) have always defended the right for indigenous communities to get legal recognition of customary land rights. Thus, when communities are in conflict with private companies or with the local government, these CSOs always try to support them. Starting in 1998 with limited community mapping, they used various other means over time to promote their objectives and help communities to secure their rights. Since 1998, more than 500,000 ha have been mapped by one of these NGOs (PPSDAK). The community mapping process was often conducted at the same time as other CSOs activities such as capacity building, community empowerment and customary laws enforcement. Other CSOs initiatives include issuance of registration certificate for sustainable community-based forest management. More recently, they implemented in West Kalimantan (including in Kapuas Hulu) a national paralegal customary territories registration system. But up to now, the law has not changed and communities' land rights are not legally recognized yet. These CSOs continue to work to help communities to secure their rights.

Thus, it is clear that these CSOs have progressively developed various approaches and tools at the regency scale to reach their objectives. While their general objective is to push the government to recognize customary land rights, their specific objectives depend on the local context. Therefore, they claims for law and policies changes and address the issue in the field with communities. While the legal context is not favorable, they often use alternative means such as demonstrations, certification, community mapping and paralegal registration systems. These CSOs 'customary land rights defenders' have been active in Kapuas Hulu since the end of 1990s. They often work together through informal and open collaborations. Actually, their relations have been strengthened over time. They build strong relations of trust and often collaborate by sharing data or advocate a same conflict case. These CSOs are not linked by contracts or any financial agreement.

In contrast, the hutan desa regulation is very recent (2008). The international NGO FFI started to promote the legal mechanism in Kapuas Hulu in 2010 (Table 6). FFI believe that village forests are a solution to avoid deforestation, to promote sustainable communities' livelihoods and to guarantee legal resources access to communities. In other words, FFI adopt a pragmatic approach based on existing laws in Indonesia. Compared to the other CSOs that favor complete community land rights recognition, FFI state that limited management rights are better than nothing. While others such as AMAN say "no rights, no REDD" (Interview 3), FFI aims to use hutan desa for community carbon pools REDD+ projects. These two movements do not share the same logic. Below, the antagonists' opinions are clearly expressed. One of the FFI's coordinator for Indonesia points out the necessity of being pragmatic and targeting "resources access and management rights recognition" in the short-term rather than to be idealistic and target the mirage of "customary land rights recognition". In contrast, an activist from AMAN criticizes the village forest mechanism.

Hutan adat are still not recognized by the government. And it will be not before long time! It will maybe take 20 years or more to get a legal recognition from the government that some forests belong to customary communities. But in the same time, the government attributes oil palm plantations permits, timber concessions, etc. So, when the law about customary forests will come, there will no forest remaining and even no rights anymore for the local communities. Our strategy is different, more pragmatic. By hutan desa, we have 35 years to secure the forests. And it is enough time to fight and negotiate with the government to get hutan adat law. But if we wait for the law, the communities will have only oil palm to manage when the law will come.

Interview 29, FFI 
We reject hutan desa because this mechanism enforce the position of government and weakened the communities. It is a tool to strengthen the government and finally to never recognize the people land rights. Secondly, they say that hutan desa is only a question of management but in our perspective it is a question of exploitation, logging. Hutan desa is only a scheme to legalize the timber logged in the forests. In the context of climate change, it also becomes a requirement for small-scale REDD projects and carbon trade.[...] Then, I always say to the people of FFI to not go in the places where AMAN is working to promote hutan desa.

Interview 45, AMAN

In the field, FFI and its partners promote village forests and facilitate the application process for interested communities. In fact, FFI pilot and coordinate the program but the fieldwork is carried out by local and regional NGOs. Their collaboration is vertical and based on short-term contracts. FFI finance and mandate these NGOs to conduct specific and limited activities (in time and space). The collaboration between these CSOs is hierarchical and includes economically dependent relations between the international NGO and the local NGOs. This framework of collaboration is different to the one that 'land rights defenders' have built over time. Their collaboration is more egalitarian and nonfinancial (or almost). Their relations are also based on long-term contracts.

\section{Soft approach vs hard approach with authorities}

One of fundamental difference between the 'customary land rights defenders' and the 'village forest mechanism promoters' is their relationship to the government authority and laws. The former do not fully recognize the power of State notably on Article 33 of the Indonesian Constitution that states "The earth, water and natural resources are under the control of the State [...]". These CSOs activists often say that: "the people, the communities lived in these lands before the government came there" (Interview 45, AMAN). For instance, one of them says: "If the State does not recognize us, we do not recognize the State" (Interview 2, AMAN). In contrast, FFI, as an international NGO, recognizes the sovereignty of Indonesia on its territory and the power of laws. FFI's approach here is not about protest against laws but facilitation of implementation of existing laws.

Facing a general situation of an absence of community land rights and resources access rights recognition, two different approaches with regard to the local government have been used by CSOs. While a clear legal context exists for communities' resources access rights and limited forest management rights, FFI has chosen to work through Regulation PP49/2008. FFI promotes the village forest mechanism and lobbies the local forestry agency (dinas kehutanan) in Kapuas Hulu. Indeed, while the first agreement letter for village forests comes from the head of the regency advised by the local forestry agency, FFI has chosen to build a cooperative framework with them. FFI is actively engaged with the forestry agency in order to convince them to support new village forests demands. But, despite frequent and cordial relations, the cooperation between FFI and the forestry agency is clearly not ideal. FFI notably points out a lack of motivation and a bureaucratic and no-risk culture among civil servants. Indeed, FFI criticizes the slowness of the technical review (forestry agency) and political decision-making (head of the regency) processes. It continues to collaborate closely with the government. FFI has recently (June 2012) cofinanced a workshop on hutan desa organized by the forestry agency of Kapuas Hulu.

In contrast, the history of 'land rights defenders' movements shows that collaboration with regency authorities has never been a priority or a strategic choice for them (Table 7). Indeed, the local governmental agencies are mandated to enforce the implementation of the law; their actions are framed by the existing laws. While customary land rights are not recognized by national laws, the local government and its agencies have limited power on the issue. Thus, no clear collaboration framework exists between CSOs engaged in customary rights issues and the forestry agency. CSO activists are critical of the local government because it issues oil palm and logging concessions without the agreement of communities. According to some activists, the Kapuas Hulu government is corrupt ${ }^{20}$ and cannot be trusted.

\section{CSOs outcomes comparison}

Community-rights defenders have not got the results they wanted in terms of recognition of customary land rights. Actually, the issue is national and needs new laws and regulations revisions. In fact,

20 According to some key informants (anonymous), the head of regency and the forestry and plantation agency would receive between US\$4 and 6 per ha attributed for oil palm concessions. This information has been cross-checked, and there is no substance to it. 
Table 6. Comparison of customary land rights movement and FFI village forests approach.

\begin{tabular}{|c|c|c|}
\hline & Customary land rights defenders & $\begin{array}{l}\text { Legal community-based forest management } \\
\text { (hutan desa) facilitation }\end{array}$ \\
\hline $\begin{array}{l}\text { First activity in } \\
\text { Kapuas Hulu }\end{array}$ & 1996 & 2010 \\
\hline CSOs & local, regional, national & international NGO (+regional and local NGOs) \\
\hline $\begin{array}{l}\text { Number of CSOs } \\
\text { involved since the } \\
\text { first activity }\end{array}$ & $9-10$ & $1(+3)$ \\
\hline CSOs collaboration & $\begin{array}{l}\text { Flexible and often informal, } \\
\text { Long term, } \\
\text { Egalitarian, } \\
\text { Non economic }\end{array}$ & $\begin{array}{l}\text { Contract-based, } \\
\text { Short term, } \\
\text { Hierarchical, } \\
\text { Economic relation }\end{array}$ \\
\hline CSOs overall & $\begin{array}{l}\text { Customary land rights defense, } \\
\text { Customary land rights legal recognition }\end{array}$ & $\begin{array}{l}\text { Avoiding deforestation, } \\
\text { Forest resources access security, } \\
\text { Sustainable livelihoods from forest resources }\end{array}$ \\
\hline \multirow[t]{2}{*}{ Legal context } & Unclear and contradictory & Clear \\
\hline & $\begin{array}{l}\text { Revised constitution (2002), Basic Agrarian Law } \\
\text { (1960), Basic Forestry Law (1999), decree TAP X } \\
\text { (2001), etc. }\end{array}$ & $\begin{array}{l}\text { Law PP 49/2008 } \\
\text { Basic Forestry Law (1999) }\end{array}$ \\
\hline
\end{tabular}

national CSO movements are claiming recognition of customary land rights in Indonesia (Di Gregorio, 2011; Safitri et al. 2011).

However, community-rights defenders in the field have mapped more than 500,000 ha of customary territories in Kapuas Hulu and recently used an innovative paralegal customary land rights registration system (BRWA). The Sungai Utik success story against logging concessions has become wellknown in Indonesia. The (butan adat) delivered by LEI has been positively complimented by the Ministry of Forestry in 2008. More recently, the community-based coalition founded by ten villages in the Embaloh Hulu district has been supported by community defenders CSOs (AMAN, LBBT, PPSDAK, JKPP, Lanting Borneo). A new large-scale community mapping process is ongoing. But up to now, the results in terms of communities land rights respect by the government are uncertain. The issuance of recent oil palm plantation permits without communities' consultation suggests that the local government does not take into account existing community maps (maybe because these maps have not been shared with them by the NGOs).

In another register, FFI supported five villages that have finally got approval from the head of the regency (Table 8). Without FFI investment, it would probably not have happened. In addition, four villages contacted FFI spontaneously after hearing about village forests initiatives. This is probably linked to the intense promotion campaign for hutan desa carried out by FFI and its local partners in 35 villages across Kapuas Hulu. In fact, compared to the number of villages visited and the efforts deployed, the results for FFI are still poor. Indeed, compared to other regencies where FFI conducts the same hutan desa program, Kapuas Hulu is behind schedule. For the moment, while the head of the regency took more than one year to validate some village applications, the Ministry of Forestry has not authorized hutan desa in Kapuas Hulu yet. The process is ongoing and FFI in Jakarta continue to lobby the Ministry of Forestry to accelerate the process. Recently, FFI has financially supported a workshop on hutan desa organized by the Kapuas Hulu forestry agency. It has been an opportunity for FFI to explain its vision and projects to a large audience composed of civil servants and heads of villages.

\subsubsection{Global approach, CSOs multi-objectives and diversity of strategies}

The four examples previously detailed give a good picture of CSOs objectives and action strategies on LUP and land rights issues in Kapuas Hulu. It suggests that CSOs use various strategies and 
Table 7. Comparison of CSOs relations with government.

\begin{tabular}{|c|c|c|}
\hline & Customary land rights defenders & $\begin{array}{l}\text { Legal community-based forest } \\
\text { management (hutan desa) facilitation }\end{array}$ \\
\hline Objectives & Customary land rights legal recognition & $\begin{array}{l}\text { Legal resources access and management } \\
\text { rights }\end{array}$ \\
\hline $\begin{array}{l}\text { Legal context to reach } \\
\text { objectives }\end{array}$ & No & Yes \\
\hline $\begin{array}{l}\text { Government authority } \\
\text { recognition }\end{array}$ & No & Yes \\
\hline $\begin{array}{l}\text { Collaboration with } \\
\text { regency governement }\end{array}$ & Usually no (or pretty rare) & Yes, intense (forestry agency) \\
\hline $\begin{array}{l}\text { Collaboration with } \\
\text { national government }\end{array}$ & Lobbying, advocacy & Lobbying \\
\hline $\begin{array}{l}\text { Collaboration with } \\
\text { governement }\end{array}$ & $\begin{array}{l}\text { contestation, national level, limited } \\
\text { collaboration (BPN) }\end{array}$ & collaboration (forestry agency) \\
\hline
\end{tabular}

incontestably play an active role in these issues. Following various objectives and different logic, CSOs have provided in Kapuas Hulu interesting and sometimes very different examples of relations with the government. Relations among CSOs community also take various forms, from the most collective strategies to more individual ones.

During the last 20 years, several CSOs have worked in Kapuas Hulu on LUP, land rights and NRM issues. Depending on their objectives and priorities, they used a large range of activities that influenced LUP and customary land rights issues. While some of them tried to influence LUP policies and decisionmaking processes at the regency and provincial levels, others engaged various field activities at the village level. At the same time, depending on their relations with government, they tended to chose soft approaches or harder and controversial ones. Finally, it is possible to classify NGOs strategic approach into four categories that are represented in Figure 22 and Table 9.

- Legal mechanism facilitation: CSOs are not in a challenging position with regard to the government. At the same time, they are more interested in field actions and results than in political decision-making processes. Thus, these CSOs tend to conduct projects at the village scale and avoid conflicts with the government. Their approach consists of facilitating implementation of legal mechanisms in order to reach their local objectives. In other words, they use existing laws to implement local projects e.g. in Kapuas Hulu, the village forest facilitation used by FFI.

Table 8. Respective outcomes of customary land rights and village forest approaches.

\section{Customary land rights defenders Legal community-based forest management (hutan desa) facilitation}

\begin{tabular}{|c|c|c|}
\hline Positive & $\begin{array}{l}\text { - LEl's customary forest certification in Sungai Utik, } \\
\text { - More than 500,000 ha of customary territories } \\
\text { mapped in } 35 \text { sub-villages, } \\
\text { - BRWA system in process of implementation, } \\
\text { - The community based customary coalition } \\
\text { against oil palm (Embaloh Hulu district) }\end{array}$ & $\begin{array}{l}\text { - Head of regency letter of agreement for five } \\
\text { villages, } \\
\text { - } 4 \text { new villages applications for village forest } \\
\text { - Workshop on village forests in collaboration with } \\
\text { forestry agency and GIZ (Putussibau, June 2012) }\end{array}$ \\
\hline Negative & $\begin{array}{l}\text { - No legal recognition of customary rights, } \\
\text { - Oil palm concessions expansion }\end{array}$ & $\begin{array}{l}\text { - Delay compare to FFI in other regencies, } \\
\text { - Only five villages (out of } 35 \text { visited) have applied } \\
\text { for hutan desa }\end{array}$ \\
\hline
\end{tabular}


- Decision-making process participation and lobbying: CSOs want to influence decisionmaking processes and general views on LUP. They adopt a soft approach with government and try to build a discussion framework. They either try to participate in the decisionmaking process or carry out active lobbying with local government. These CSOs tend to recognize the power of authorities, notably the decision-making power of LUP. Thus, they aim to influence decision-makers through close relations and active participation e.g. in Kapuas Hulu, the participation of WWF and FFI in the RTRW-K process.

- Land-conflict cases advocacy: CSOs reject government decisions and laws at the national, provincial and regency scale. At the same time, their actions take place at the local scale with communities. Indeed, rather than challenging the government in the policy arena, these CSOs empower communities and defend customary land rights at the village scale. They often intervene in a tense and sometimes conflictual context between communities and private companies (logging, oil palm). LBBT and AMAN support to some villages in Kapuas Hulu is a perfect example of this.

- Large advocacy coalitions: CSOs disagree with government decisions or general LUP strategies.
If these CSOs are sufficiently numerous, they build together a collective movement to press the government at the provincial (and national) scale. Together they become stronger to influence LUP issues in general. These advocacy coalitions target oil palm expansion, illegal logging and nonparticipative spatial plans.

It seems that international conservation NGOs such WWF and FFI tend to use soft approaches with the government. In contrast, some Indonesian NGOs (and particularly the ones who pursue customary land rights objectives) engage harder approaches with the government. Both categories are active at the local scale (village) and at the regency or provincial scale.

LUP decision-making processes take place at the regency and provincial scales. Participation during these processes depend on government and CSO attitudes. It appears that the openness of authorities towards civil society participation influences the reaction of CSOs. But at the same time, the government openness seems to depend on the objectives of the CSOs. In Kapuas Hulu, the government heard the conservationists NGOs arguments but were not as open to the arguments of the community-rights defenders. We have identified in Kapuas Hulu, two general CSOs approaches

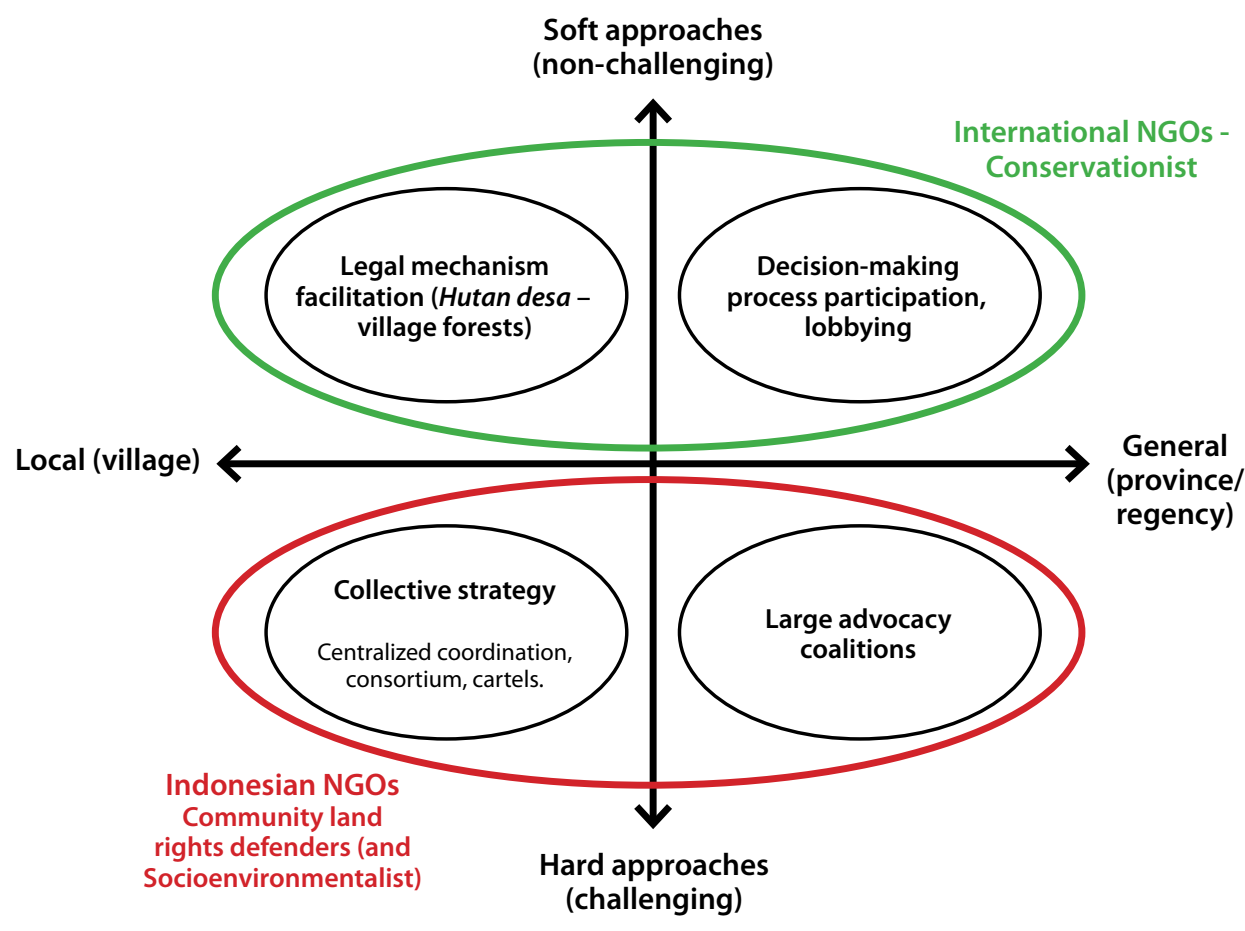

Figure 22. Soft vs hard approaches and local vs policy approaches. 
Table 9. Comparison of four CSOs strategic approaches.

\begin{tabular}{|c|c|c|c|c|}
\hline & $\begin{array}{l}\text { Legal mechanism } \\
\text { facilitation }\end{array}$ & $\begin{array}{l}\text { Decision-making } \\
\text { process participation } \\
\text { and lobbying }\end{array}$ & $\begin{array}{l}\text { Land-conflict cases } \\
\text { advocacy }\end{array}$ & $\begin{array}{l}\text { Large advocacy } \\
\text { coalitions }\end{array}$ \\
\hline Scale of action & Village & Regency & Village & Province \\
\hline $\begin{array}{l}\text { Approch with } \\
\text { the government }\end{array}$ & soft & soft & hard & hard \\
\hline CSOs & International NGOs & International CSOs & $\begin{array}{l}\text { Local, regional, } \\
\text { national CSOs }\end{array}$ & $\begin{array}{l}\text { Local, regional, } \\
\text { national, international } \\
\text { CSOs }\end{array}$ \\
\hline $\begin{array}{l}\text { General } \\
\text { objectives }\end{array}$ & Conservation & Conservation & $\begin{array}{l}\text { Customary land } \\
\text { rights respect and } \\
\text { recognition }\end{array}$ & $\begin{array}{l}\text { Socioenvironmental } \\
\text { justice }\end{array}$ \\
\hline $\begin{array}{l}\text { Relations } \\
\text { among CSOs }\end{array}$ & $\begin{array}{l}\text { Individual strategy } \\
\text { or contract-based } \\
\text { relations }\end{array}$ & $\begin{array}{l}\text { Individual strategy or } \\
\text { positive cohabitation }\end{array}$ & $\begin{array}{l}\text { Network, } \\
\text { complementarity, } \\
\text { long-term relations }\end{array}$ & $\begin{array}{l}\text { Coordination, active } \\
\text { collaboration, network, } \\
\text { collective action }\end{array}$ \\
\hline Examples & $\begin{array}{l}\text { - FFI village forest } \\
\text { mechanism } \\
\text { facilitation (2010- } \\
\text { 2012), } \\
\text { - WWF reforestation } \\
\text { projects along } \\
\text { Mandalam river } \\
\text { for Payment for } \\
\text { Environment } \\
\text { Services (2006-2012) } \\
\text { - WWF community } \\
\text { plantations projects } \\
\text { in ecological corridor } \\
\text { area (2010) }\end{array}$ & $\begin{array}{l}\text { WWF support for } \\
\text { Betun Kerihung } \\
\text { National Park } \\
\text { management plan } \\
\text { elaboration (1995- } \\
\text { 2002) } \\
\text { - WWW participation } \\
\text { to the Heart of } \\
\text { Borneo working } \\
\text { group in Kapuas } \\
\text { Hulu (2011-2012) } \\
\text { - WWF support } \\
\text { to BAPPEDA for } \\
\text { ecological corridor } \\
\text { strategic area } \\
\text { management plan } \\
\text { elaboration (2012) } \\
\text { FFI, WWF and } \\
\text { SEKALA participation } \\
\text { to the RTRW-K } \\
\text { revision process in } \\
\text { Kapuas Hulu (2010) }\end{array}$ & $\begin{array}{l}\text { - AMAN and } \\
\text { LBBT support } \\
\text { to Mandalam } \\
\text { communities in } \\
\text { conflict with a } \\
\text { logging company } \\
\text { (1997, 2003, 2010) } \\
\text { - Various CSOs } \\
\text { support to Sungai } \\
\text { Utik village in } \\
\text { conflict with logging } \\
\text { companies (1996- } \\
\text { 200?) } \\
\text { - LEI customary forest } \\
\text { certification in } \\
\text { Sungai Utik } \\
\text { - AMAN and LBBT } \\
\text { support to Embaloh } \\
\text { Hulu communities } \\
\text { rejecting an oil palm } \\
\text { concession (2011- } \\
\text { 2012) } \\
\text { JKPP and Lanting } \\
\text { Borneo large scale } \\
\text { community mapping } \\
\text { project in Embaloh } \\
\text { Hulu (2012) }\end{array}$ & $\begin{array}{l}\text { - Coalition anti- } \\
\text { illegal logging KAIL } \\
\text { (2004-2005) } \\
\text { - The coalition to save } \\
\text { the Heart of Borneo } \\
\text { (2005) } \\
\text { - The civil society } \\
\text { coalition for } \\
\text { sustainable and fair } \\
\text { spatial planning in } \\
\text { West Kalimantan } \\
\text { (2011-2012) }\end{array}$ \\
\hline
\end{tabular}

when they want to influence the government. While both conservationists and land rights defenders have disagreements with the local government, CSOs participation in environmental issues seems to be more accepted by government than customary land rights recognition demands. Indeed, while conservation can be applied in various ways, people land rights official recognition needs new national laws and regulations (Figure 23).
- Soft approach based on negotiation and lobbying: In this situation, CSOs generally disagree with government but are allowed to participate in decision-making processes. CSOs will use their participation to engage the government through discussions and lobbying. They chose a soft approach in order to avoid open conflict with the government that would cause them to be thrown out of the participative 
process. Despite disagreements with some people in the government, they find allies among authorities. These CSOs prefer dialogue and argument to direct confrontation. This might be because government accept hearing the views of powerful international NGOs more than local NGOs.

- Hard approach, power struggle and challenging attitude: CSOs decide to challenge the government only if they are disappointed by participation level and strongly disagree with the government's objectives. Usually, CSOs use conflict and a hard approach with the government when its choices and general orientation are considered to be bad. In this situation, CSOs have nothing to lose because their objectives are not being fulfilled by the government. The only solution for them is to challenge the government and engage in a power struggle. While community land rights are not recognized in the West Kalimantan LUP, customary land rights defenders tend to take hard approaches.

The reality is far more complex. According to the cases studies in Kapuas Hulu, I have identified some general and simple trends about CSOs roles in LUP and land rights issues. I called them 'the soft international conservationists approach' and 'the community-rights-based hard and collective approach'. Each of these two approaches tends to occur in particular and multifactoral contexts. Table 10 outlines the two approaches and shows the general trends.

While these two approaches cannot be conducted at the same time by the same CSOs, they are compatible in the same space and probably complementary to each other. In order to get a sustainable and fair land-use plan, CSOs share these roles; they discuss with government on one hand and challenge it on the other hand.

\subsection{General discussion on CSOs roles in Kapuas Hulu}

Land-use planning and land rights issues have attracted a significant amount of attention among CSOs working in Kapuas Hulu. Their various strategies and numerous activities reflect the general dynamism of CSOs in Kapuas Hulu. Indeed, this extensively forested regency contains both highly sensitive environmental issues and complex indigenous communities' rights issues. While in other regencies, community-rights and conservation

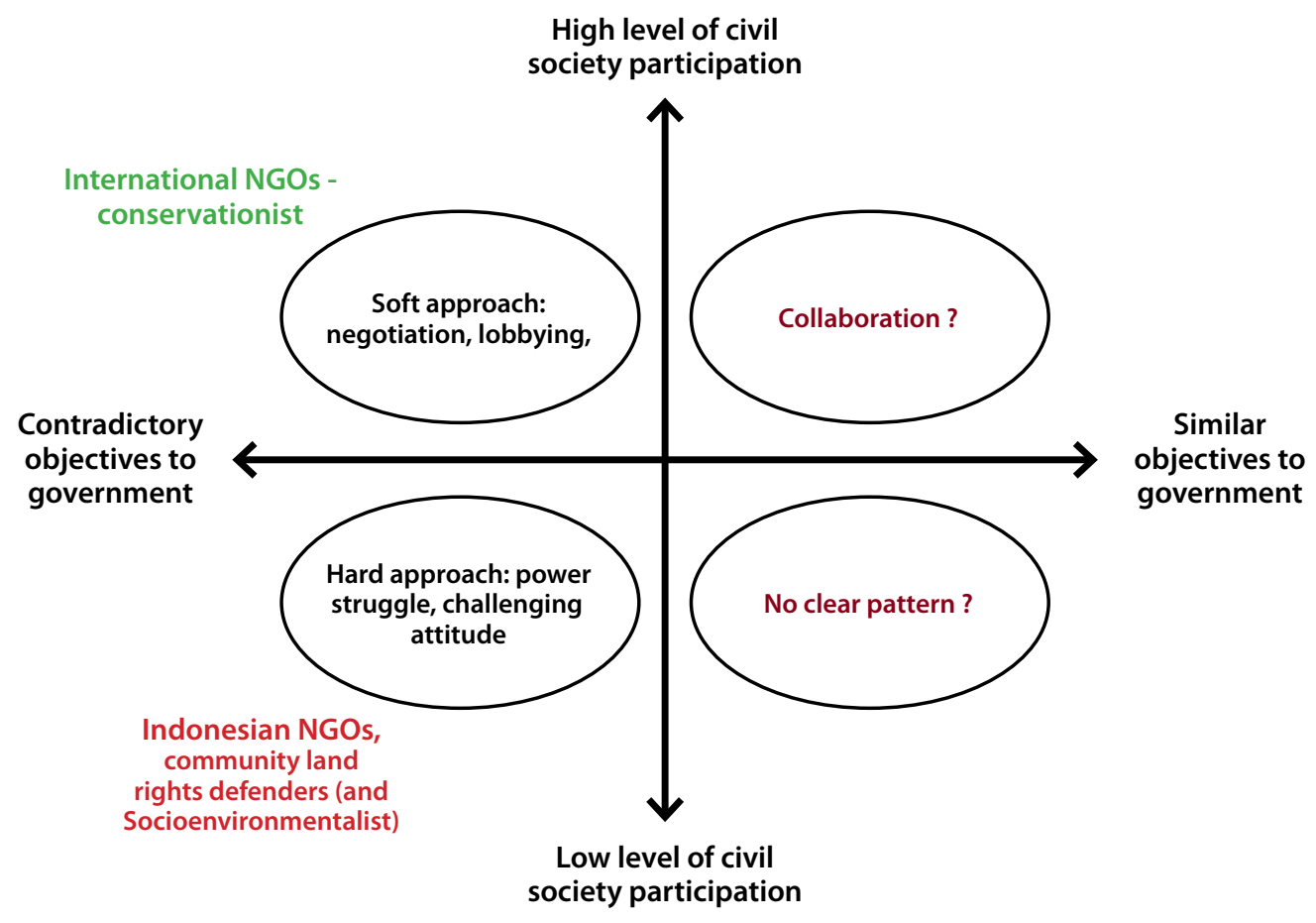

Figure 23. CSOs approaches depending on the objectives and the level of participation. 
Table 10. Soft international conservationists approach vs community-rights based hard and collective approach.

\begin{tabular}{ll}
\hline Soft international conservationists approach & Community-rights based hard and collective approach \\
\hline Conservationists international NGOs & Indonesian CSOs 'customary land rights defenders' \\
Individual strategies and contract-based relations & Large-scale collective strategies and long-term alliances \\
Soft approaches with government & Hard approaches with government \\
Government allowed CSOs participation & Government ignores CSOs participation rights \\
$\begin{array}{l}\text { Positive local outcomes for conservation but general } \\
\text { expansion of oil palm plantations }\end{array}$ & Few successes but general weak tenure security for \\
$\begin{array}{l}\text { Communities resources access rights for conservation } \\
\text { purposes }\end{array}$ & Communities \\
Clear legal context to reach the objectives & \\
\hline
\end{tabular}

face a tremendous and fast expansion of oil palm sector, Kapuas Hulu is still relatively preserved. Thus, while most of the oil palm companies implemented in Kapuas Hulu have not started to clear the land, CSOs still have a role to play. And that is exactly what they do by mixing soft approaches and hard approaches with the government.

But another approach has not been presented here. Indeed, several CSOs conduct local and short-term projects without any particular relationship with the government. These CSOs do not challenge the government and they do not collaborate with it. Rather than targeting a decision-making process or peoples rights issue, many CSOs in Kapuas Hulu conduct simple projects with Socioenvironmental justice objectives. For instance, thanks to donors, various regional NGOs conduct projects to enhance people livelihoods through marketing non-wood forest products (dian tama). Others encourage collective management of national parks (Riak Bumi, Wetlands International, Tropenbos). Thus, CSO roles in LUP in Kapuas Hulu should be discussed in a global way, not only in terms of interrelations and relations with government.

With 23 CSOs involved in LUP, land rights and NRM issues since 1992, Kapuas Hulu is a very good example of multilevel and multi-objective actions carried out by CSOs. Their combined strategies and objectives associated with several field projects make them important stakeholders of LUP issue in Kapuas Hulu. While they together pursue an overall goal of Socioenvironmental justice, they contribute to influencing LUP policies and implementation. However, they face a big challenge because of the oil palm sector development objectives of the local government. The lands opened for conversion represent around 30\% of the Kapuas Hulu area. The oil palm sector has already claimed several exploitation permits. Thus, CSOs will have to manage new trends and powerful actors such oil palm companies. Both conservation and people's rights will be threatened by a likely oil palm sector expansion.

While the CoLUPSIA project aims to promote collaborative land-use planning for sustainable arrangements, CSOs in Kapuas Hulu appears to be inevitable interlocutors. Thus, I believe that any sustainable arrangement for Kapuas Hulu land-use plan should involve the different kinds of NGOs. Conservationists, Socioenvironmental justice supporters and customary rights defenders should be associated in any collective process of reflection. It seems necessary to balance the political and legislative power of government and the tremendous economic power of the private sector. While government and companies agree to develop a 'capitalistic' economy on natural resources exploitation and intensive landuse, CSOs should probably open a large discussion framework to organize a collective and structured multilevel and multi-objective strategy. 


\section{Conclusion}

Land-use planning in Indonesia has been progressively decentralized and theoretically open to civil society participation. At the same time, customary land rights are not practically recognized by the government. CSOs who work in this domain have been largely ignored by the local authorities. At the national and local scale, the government use the public interest principle to issue millions of hectares of private extractive concessions. The situation in Kapuas Hulu regency follows this general context. Thus, I have conducted research in order to understand and describe the roles played by civil society organizations on land-use planning and land rights issues. We have found that several CSOs (mainly NGOs) have been active on these issues in Kapuas Hulu. They are local, regional, national and international CSOs. In general, their objectives are about conservation, Socioenvironmental justice and recognition of customary land rights. Thus, while some of them (the conservationist international NGOs) prefer soft approaches and negotiations with the government, others engage power struggles and direct confrontation. They usually collaborate through networking and project complementarity or through coordinated and organized advocacy coalitions. In Kapuas Hulu, the LUP process has been followed and partially influenced by international NGOs. But at the same time, a provincial coalition has been created to denounce the West Kalimantan spatial plan. Different CSOs are trying to influence LUP with lobbying and soft participation or through confrontation and power struggles. While the former act in a decision-making process at the regency scale, the latter denounces the situation on the whole provincial scale. At the same time in the field, an international organization uses a legal mechanism on village forests to help communities to get management and access rights. Other more radical Indonesian NGOs continue to claim for the recognition of customary land rights. Legal mechanism implementation and conflict cases advocacy (associated with community mapping) are the contribution of CSOs to the community land rights issue. All these actions influence LUP and community land rights issues in Kapuas Hulu. As LUP and community land rights issues are connected to provincial and national levels, the influence of CSOs should be studied from a multilevel perspective. This work is a limited contribution to a far wider set of research questions on CSOs influence on environmental and social issues in Indonesia. Researchers may study and analyze multidimension CSO network (vertical and horizontal) functioning and their general and specific impacts on LUP, community-rights and natural resources management at different scales in Indonesa. Why not imagine an ambitious research project as a contribution to governance programs? A multidisciplinary team of researchers would certainly be able to provide a good academic contribution to social and political sciences and innovative ideas on LUP and community land rights issues in Indonesia, and more generally in developing countries. 


\section{References}

Ahlenius H. 2007. Extent of deforestation in Borneo 1950-2005, and projection towards 2020. Last stand of the orangutan, rapid response assessment. UNEP/ GRID-Arendal.

Akiefnawati R, Villamor GB, Zulfikar F, Budisetiawan I, Mulyoutami E, Ayat A and van Noordwijk M. 2010. Stewardship agreement to reduce emissions from deforestation and degradation (REDD): Case study from Lubuk Beringin's Hutan desa, Jambi Province, Sumatra, Indonesia. International Forestry Review 12(4):349-360.

Alexander ER. 1991. Approaches to Planning: Introducing Current Planning Theories, Concepts, and Issues, Philadelphia, PA: Gordon and Breach Science Publishers.

Anheier HK. How to measure civil society. Centre for Civil Society. London School of Economics. http://fathom.lse.ac.uk/features/122552/

Antlov H, Rustam I and van Tuijl P. 2005. NGO governance and accountability in Indonesia: Challenges in a newly democratizing country. In Jordan L and van Tuijl P, eds. NGO Accountability: Politics, Principles, and Innovations. London: Earthscan. 147-166.

BAPPEDA. 2011. Presentation RTRW Kapuas Hulu. Pemaparan RTRW Kabupaten Kapuas Hulu. Putussibau.

Barr CM. 2006. Decentralization of forest administration in Indonesia: Implications for forest sustainability, economic development, and community livelihoods. Bogor, Indonesia: CIFOR.

Casson A and Obidzinski K. 2002. From new order to regional autonomy: Shifting dynamics of 'illegal' logging in Kalimantan, Indonesia. World Development 30(12):2133-51.

[CCS] Centre for Civil Society. 2009. What is civil society? London School of Economics. www.lse. ac.uk/collections/CCS/ introduction/what_is_ civil_society.htm

Chandhoke N. 2002. The limits of global civil society. In Marlies G, Kaldor M and Anheier H. Global Civil Society. 35-53.

[CIVISCUS], Civil Society Index. 2011 Summary of conceptual framework and research methodology.
https://www.civicus.org/new/media/CSI_ Methodology_and_conceptual_framework.pdf. Clerc J. 2010. Unpacking tenure security: development of a conceptual framework and application to the case of oil palm expansion on customary land in Kapuas Hulu regency, West Kalimantan, Indonesia. [Master's thesis] Montpellier, France: AgroParisTech-Engref.

Colchester M. 2006. Promised land: Palm oil and land acquisition in Indonesia: Implications for local communities and indigenous peoples. Forest Peoples Programme and Sawit Watch. England; Bogor, West Java: Forest Peoples Programme; Perkumpulan Sawit Watch; HuMA; World Agroforestry Centre.

Corry O. 2010. Defining and theorizing the third sector. In Taylor R, ed. Third Sector Research. New York, NY: Springer. 11-20. [Accessed 22 July 2012. http://www.springerlink.com/ index/10.1007/978-1-4419-5707-8_2

Crozier M and Friedberg E. 1977. L'acteur et le système. Les contraintes de l'action collective. Collection Sociologie politique. Paris: Editions du Seuil.

Deddy K. 2005. Community mapping, tenurial rights and conflict resolution in Kalimantan. In Cooke FM. State, Communities and Forests in Contemporary Borneo. Canberra, Australia. 224

Di Gregorio M. 2011. Social movement networks, policy processes, and forest tenure activism in Indonesia. London School of Economics and Political Science (LSE).

Durey L. 2011. The Land-Use Planning in Indonesian Moluccas: A Tool for Communities' Tenure Securitization? Cergy-Pontoise, France: ISTOM.

Edwards M. 2004. Civil Society. Malden, MA: Polity Press.

Eilenberg M. 2012. At the Edges of States: Dynamics of State Formation in the Indonesian Borderlands, Leiden, Netherlands: KITLV Press.

[FAO] Food and Agriculture Organization of the United Nations. 2010. Global Forest Resources Assessment Indonesia. Rome: FAO.

[FAO] Food and Agriculture Organization of the United Nations. 2007. Good Governance in Land Tenure and Administration. Rome: FAO. 
Foley MV and Edwards B. 1996. The paradox of civil society. Journal of Democracy 7(3):38-52.

Foudriat M. 2007. Sociologie des organisations : la pratique du raisonnement. Paris: Pearson Education.

Friedberg E. 1993. Le pouvoir et la règle: dynamiques de l'action organisée. Paris: Ed. du Seuil.

Fung A. 2006. Varieties of participation in complex governance. Public Administration Review 66(s1):66-75.

Graham W. 2005. The Role of Environmental Movement Organizations in Land-use Planning: Case Studies of the Niagara Escarpment and Oak Ridges Morain Processes. Waterloo, Ontario, Canada: University of Waterloo.

Hadiwinata BS. 2003. The Politics of NGOs in Indonesia: Developing Democracy and Managing a Movement. London: RoutledgeCurzon.

Harwell EE. 2006. The un-natural history of culture: Ethnicity, tradition and territorial conflicts in West Kalimantan, Indonesia, 1800-1997. [PhD thesis] New Haven, CT:Yale.

Hudalah D and Woltjer J. 2007. Spatial planning system in transitional Indonesia. International Planning Studies 12(3):291-303.

Ibrahim R. 2006. Indonesian Civil Society. Jakarta, Indonesia: CIVICUS.

Johnson E and Prakash A. 2007. NGO research program: A collective action perspective. Policy Sciences 40(3):221-40.

Komarudin H, Siagian Y and Colfer C. 2008. Collective action to secure property rights for the poor. A case study in Jambi Province, Indonesia. CAPRI-CGIAR.

Le Roy F and Yami S. 2007. Les stratégies collectives : rivaliser et coopérer avec ses concurrents. In Éd. EMS, Management \& Société.

Lewis D. 2002. Civil Society in African contexts: Reflections on the usefulness of a concept. Development and Change 33(4):569-86.

Moeliono MMM, Wollenberg E and Limberg G. 2009. The Decentralization of Forest Governance Politics, Economics and the Gight for Control of Forests in Indonesian Borneo. London; Sterling, VA: Earthscan. http://search.ebscohost.com/ login.aspx?direct=true $\&$ scope $=$ site $\& \mathrm{db}=$ nlebk $\& \mathrm{~d}$ $\mathrm{b}=$ nlabk\&AN $=250570$

Peluso NL and Vandergeest P. 2001. Genealogies of the political forest and customary rights in Indonesia, Malaysia, and Thailand. Journal of Asian Studies 60(3):761.

Potter L. 2008. Dayak resistance to oil palm plantations in West Kalimantan, Indonesia.
In 17th Biennial Conference of the Asian Studies Association of Australia, Melbourne, 1-3 July 2008.

Priatna D, Darcy L and Percey S. 2010. To what extent are the RSPO biodiversity P\&C supported and recognised by the spatial planning processes that determine where oil palm expansion occurs? Zoological Society of London.

Ribot JC and Peluso NL. 2003. A theory of access. Rural Sociology 68(2):153-81.

[RRI] Rights and Resources Initiative and International Tropical Timber Organization. 2009. Tropical Forest Tenure Assessment Trends, Challenges and Opportunities, Washington DC, USA.

Roy I. 2008. Civil society and good governance: (Re-) conceptualizing the interface. World Development 36(4):677-705.

Safitri MA, Muhshi MA, Muhajir M, Shohibuddin M, Arizona Y, Sirait M, Nagara G, Andiko, Moniaga S, Berliani H. et al. 2011. Towards certainty and justice in tenure. The views of the Indonesian civil society groups concerning the principles, prerequisites and measures in reforming the policies on the control of land and forest zones in Indonesia. Jakarta, Indonesia.

Santoso H. 2003. Forest area rationalization in Indonesia: A study on the forest resource conditions and policy reform. SEA Regional Office: World Agroforestry Center.

Schlager E and Ostrom E. 1992. Property-rights regimes and natural resources: A conceptual analysis. Land Economics 68(3):249-62.

Singer B. 2009. Indonesian forest-related policies. A multisectoral overview of public policies in Indonesa's forests since 1965. [part of PhD thesis] Institute d'Etudes Politiques and CIRAD, France.

Suharko. 2011. The limits of Indonesian CSOs in promoting democratic governance. In Kimura $\mathrm{H}$, Suharko, Javier AB and Tansupvattana A, eds. 2011. Limits of Good Governance in Developing Countries. Yogyakarta, Indonesia: Gadjah Mada University Press.

Tarrow S. 2011. Power in Movement: Social Movements, Collective Action and Politics. Cambridge: Cambridge University Press.

[USAID] United States Agency for International Development. 2011. Property rights and resource governance in Indonesia. Washington, DC: USAID.

Wakker E. 2006. The Kalimantan border oil palm mega-project. Amsterdam, The Netherlands: AIDEnvironment.

Wicke B, Sikkema R, Dornburg V and Faaij A. 2011. Exploring land-use changes and the role of palm 
oil production in Indonesia and Malaysia. Landuse Policy 28(1):193-206.

Winoto J. 2009. Taking land policy and administration in Indonesia to the next stage and national land agency's strategic plan. In Workshop in International Federation of Surveyors' Forum. Washington, DC.

Wollenberg E, Campbell B, Dounias E, Gunarso P, Moeliono M and Sheil D. 2009. Interactive land-use planning in Indonesian rain-forest landscapes: Reconnecting plans to practice. Ecology and Society 14(1):35.

Wollenberg E, Moeliono M, Limberg G, Iwan R, Rhee $S$ and Sudana M. 2006. Between state and society: Local governance of forests in Malinau, Indonesia. Forest Policy and Economics 8(4):421-33.
World Bank. 2010. Defining civil society. World Bank Washington, DC. http://web.worldbank. org/WBSITE/EXTERNAL/TOPICS/CSO/ 0,,contentMDK:20101499 menuPK:2447 52 pagePK:220503 piPK:220476 -theSite PK:228717,00.html

Yasmi Y. 2007. Institutionalization of Conflict Capability in the Management of Natural Resources: Theoretical Perspectives and Empirical Experience in Indonesia. Wageningen: S.N.

Yuliani L, Indriatmoko Y, Salim A, Farid IZ, Muhajir M, Prasetyo LB and Heri V. 2010. Biofuel policies and their impact on local people and biodiversity: A case study from Danau Sentarum. Borneo Research Bulletin 41:109-44. 


\section{Appendices}

Appendix 1. Oil palm land information and location permits in Kapuas Hulu.

\begin{tabular}{|c|c|c|c|c|c|c|}
\hline \multirow[t]{2}{*}{ No. } & \multirow[t]{2}{*}{ Company name } & \multirow{2}{*}{$\begin{array}{l}\text { Plantation location } \\
\text { (District) }\end{array}$} & \multicolumn{2}{|c|}{ Land information } & \multicolumn{2}{|c|}{ Location permit } \\
\hline & & & Date & Area $(\mathrm{Ha})$ & Date & Area $(\mathrm{Ha})$ \\
\hline \multirow[t]{2}{*}{1} & \multirow{2}{*}{$\begin{array}{l}\text { PT. RIAU AGROTAMA } \\
\text { PLANTATION }\end{array}$} & Silat Hilir & & & 10-July-01 & 18,000 \\
\hline & & Silat Hilir, Seberuang & 29-May-08 & 10,000 & $10-S e p t-08$ & 10,000 \\
\hline 2 & PT. ANUGERAH MAKMUR SEJATI & Silat Hilir, Seberuang & 06-Sept-06 & 15,000 & 12-May-09 & 12,350 \\
\hline 3 & $\begin{array}{l}\text { PT. KAPUASINDO PALM } \\
\text { IDUSTRY }\end{array}$ & Empanang, Semitau & 27-Dec-06 & 18,000 & 12-May-09 & 19,000 \\
\hline 4 & PT. PERSADA GRAHA MANDIRI & Silat Hilir & 04-Aug-06 & 20,000 & 12-May-09 & 19,750 \\
\hline 5 & PT. PRIMANUSA MITRA SERASI & Silat Hilir, Silat Hulu & 06-Sept-06 & 20,000 & 12-May-09 & 17,700 \\
\hline 6 & PT. KARTIKA PRIMA CIPTA & $\begin{array}{l}\text { Semitau, Suhaid, } \\
\text { Selimbau }\end{array}$ & 04-Aug-06 & 20,000 & 12-May-09 & 19,200 \\
\hline 7 & $\begin{array}{l}\text { PT. PARAMITRA INTERNUSA } \\
\text { PRATAMA }\end{array}$ & Silat Hilir, Semitau & 04-Aug-06 & 20,000 & 12-May-09 & 20,000 \\
\hline 8 & PT. BUANA TUNAS SEJAHTERA & Badau & 22-Dec-06 & 16,000 & 12-May-09 & 15,500 \\
\hline 9 & $\begin{array}{l}\text { PT. SENTRA KARYA } \\
\text { MANUNGGAL }\end{array}$ & Empanang, Badau & 28-Feb-07 & 20,000 & 12-May-09 & 20,000 \\
\hline 10 & PT. DUTA NUSA LESTARI & Semitau & 12-Sept-07 & 17,500 & 12-May-09 & 17,500 \\
\hline 11 & PT. SAWIT KAPUAS KENCANA & $\begin{array}{l}\text { Puring Kencana, } \\
\text { Empanang }\end{array}$ & 06-Nov-07 & 27,000 & 08-Oct-09 & 18,000 \\
\hline 12 & PT. DINAMIKA MULTI PRAKARSA & Semitau & 31-Aug-10 & 6,165 & 28-Oct-10 & 6,165 \\
\hline 13 & PT. CITRANUSA INDOMAKMUR & Puring Kencana & 31-Aug-10 & 10,024 & $28-O c t-10$ & 10,024 \\
\hline 14 & $\begin{array}{l}\text { PT. BORNEO INTERNATIONAL } \\
\text { ANUGERAH }\end{array}$ & $\begin{array}{l}\text { Bika, Putussibau } \\
\text { Selatan, Embaloh Hilir, }\end{array}$ & 06-Sept-06 & 20,000 & 26-Nov-09 & 20,000 \\
\hline 15 & PT. WAHANA HAMPARAN HIJAU & Mentebah, Bunut Hulu & 06-Sept-06 & 20,000 & 26-Nov-09 & 19800 \\
\hline 16 & PT. BERKAH SAWIT ABADI & $\begin{array}{l}\text { Selimbau, Pengkadan, } \\
\text { Jongkong }\end{array}$ & 06-Sept-06 & 20,000 & 26-Nov-09 & 18000 \\
\hline 17 & PT. MITRA KAPUAS AGRO & $\begin{array}{l}\text { Boyan Tanjung, Bunut } \\
\text { Hulu, Mentebah, Bunut } \\
\text { Hilir, Jongkong }\end{array}$ & 06-Sept-06 & 20,000 & 26-Nov-09 & 19,700 \\
\hline 18 & PT. KHATULISTIWA AGRO ABADI & Batang Lupar, Badau & 22-Dec-06 & 17,000 & 26-Nov-09 & 17,000 \\
\hline 19 & PT. KAPUAS BIO AGRO & Batang Lupar & 22-Dec-08 & 17,000 & 26-Nov-09 & 17,000 \\
\hline \multirow[t]{2}{*}{20} & PT. BORNEO ESTATE SEJAHTERA & $\begin{array}{l}\text { Bunut Hilir, Embaloh } \\
\text { Hilir }\end{array}$ & 27-Dec-06 & 14,000 & 27-April-07 & 14,000 \\
\hline & & $\begin{array}{l}\text { Bunut Hilir, Boyan } \\
\text { Tanjung }\end{array}$ & 23-April-10 & 3,700 & & \\
\hline 21 & PT. KAPUAS AGRO MANDIRI & $\begin{array}{l}\text { Kalis, Bika, Putussibau } \\
\text { Selatan }\end{array}$ & 11-Sept-09 & 20,000 & $08-f e b-10$ & 20,000 \\
\hline 22 & PT. AGRO CITRA ABADI & Embaloh Hulu, Bika, & 11-Sept-09 & 17,000 & $08-f e b-10$ & 17,000 \\
\hline \multirow[t]{2}{*}{23} & PT. BUMI TANI JAYA & Bunut Hilir, Jongkong & 29-Nov-07 & 18,000 & 08-oct-09 & 20,900 \\
\hline & & TOTAL & & 406,389 & & 406,589 \\
\hline
\end{tabular}

Source: Kapuas Hulu Forestry and Plantation Agency, 2012. 


\section{Appendix 2. Oil palm concession issuance process.}

Based on Ministry of Agriculture Decree No.26/Permentan/ar.140/2/2007

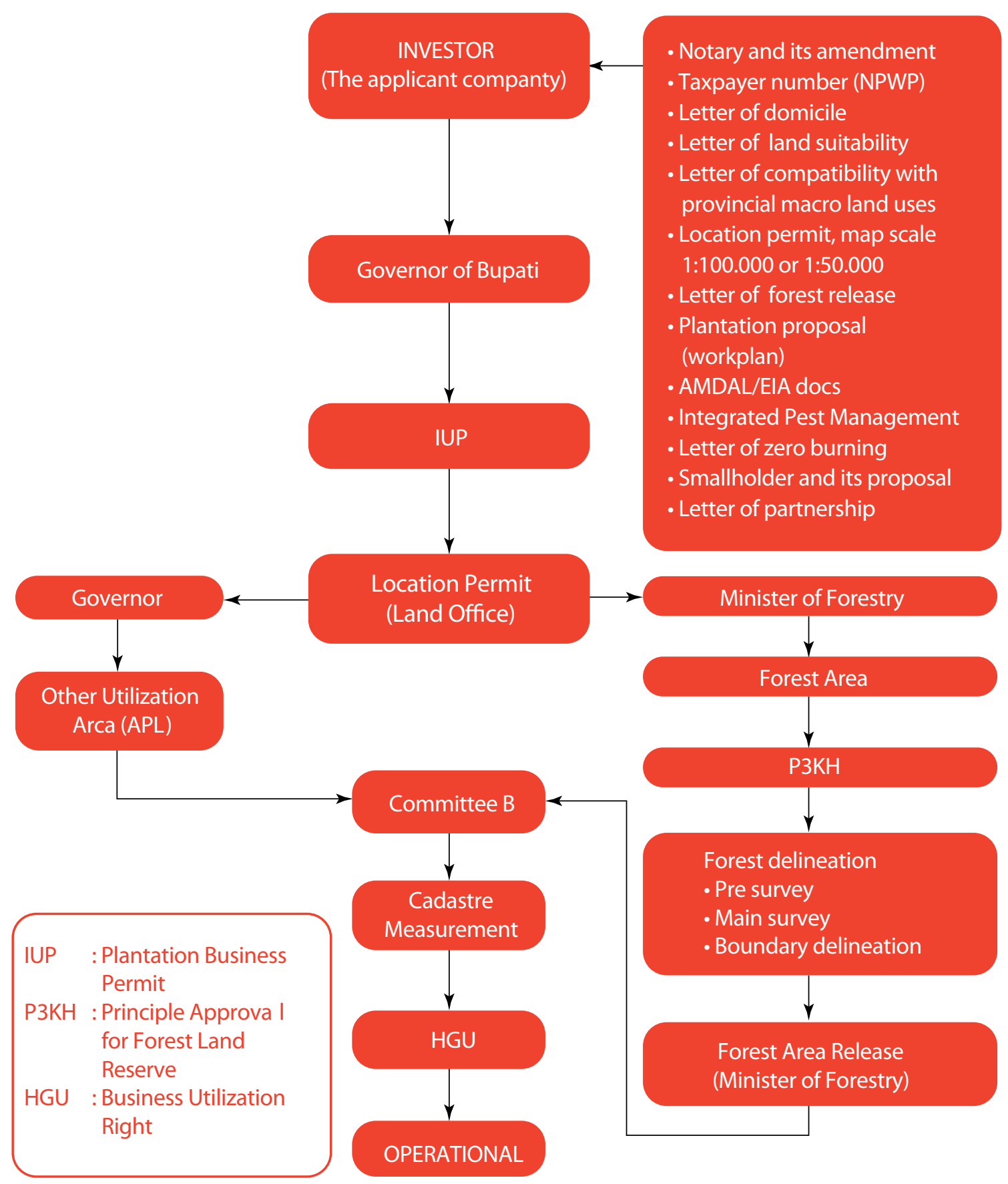




\title{
Appendix 3. Interview guide for civil society organizations
}

\section{CSOs Interview guide}

\author{
Date/Tanggal: \\ Location/Lokasi: \\ Audio recording/Rekaman suara:

\section{Basic information/Informasi Pokok}

\section{Name of the CSO/Nama CSO:}

\subsection{Respondent}

Name(s) of the respondent(s)/Nama(-nama) responden:

Function-position/Fungsi-Posisi:

Level of education: $\square$ Doctor (Phd), $\square$ Master degree, $\square$ undergraduate, $\square$ Ujian nasional, $\square$ secondary school, $\square$ primary school

Tingkat pendidikan: $\square$ Doktor (Phd), $\square$ Master, $\square S 1, \square$ Ujian nasional, $\square S M A, \square S D / S M P$

Contact/Kontak:

\subsection{Organization information}

Type of CSO/Jenis organizasi:

$\square$ International NGO/ $\square$ National NGO/ $\square$ local NGO/ $\square$ National network/ $\square$ peasant group/ $\square$ foundation/ $\square$ Institut/ $\square$ Community group/ $\square$ Research Center or university/ $\square$ other:

$\square$ NGO internasional/ $\square$ NGO Nasional/ $\square$ NGO lokal/ $\square$ Jaringan nasional/ $\square$ Kelompok tani/ $\square$ Yayasan/ $\square$ Institut/ $\square$ Kelompok masyarakat/ $\square$ Pusat Penelitian or university/ $\square$ Lainnya:

If not local, where is the headquarter?

Jika bukan organisasi lokal, di mana kantor pusatnya? ...

Are there other offices in Kapuas Hulu? Where?

Apakah ada kantor-kantor lain di Kapuas Hulu? Di mana?

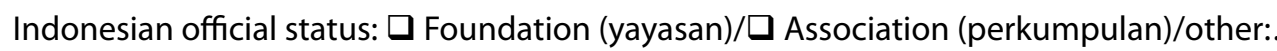

Status resmi di Indonesia: $\square$ Yayasan/ $\square$ Perkumpulan/Lainnya:

Domains of activity: $\square$ Environment-Conservation/ $\square$ Agriculture/ $\square$ Indigenous communities/ $\square$ Social issues/ $\square$ Landuse planning/ $\square$ Forest Management/ $\square$ Natural Resources Management, $\square$ other

Bidang kegiatan: $\square$ Lingkungan-Konservasi/ $\square$ Pertanian/ $\square$ Masyarakat adat/ $\square$ Isu-isu sosial/ $\square$ Perencanaan Penggunaan Lahan/ $\square$ Pengelolaan Hutan/ $\square$ Pengelolaan Sumber Daya Alam/ $\square$ lainnya ....

Priority domains (1 or 2):

Bidang prioritas (1 atau 2):

Date of creation or arrival in Indonesia:

Tanggal pembentukan atau kehadiran di Indonesia:

Date of the first activity in the district of Kapuas Hulu:

Tanggal pembentukan atau kehadiran di Indonesia:

Date of the last activity in Kapuas Hulu:

Tanggal kegiatan terakhir di Kapuas Hulu:

\subsection{Structure and employees}

Number of Employees/Berapa Karyawan:

Education level of employees:

.... Doctor (Phd), .... Master degree, .... undergraduate, .... Ujian nasional, .... secondary school, .... primary school Tingkat pendidikan karyawan: .... Doktor (Phd), .... Master, ... S1, ... Ujian nasional, ... SMA, .... SD/SMP Number of Volunteers (frequency)/Sukarelawan (frekwensi): 
Do the director is also the founder (or is he/she elected? How often?)/Apakah Direktur juga pendiri (dipilih?):

Spoken languages/Bahasa lisan yang digunakan:

Specific departments or services, organization's structure, hierarchy, office/field staff

Divisi atau layanan, structure organisasi, pengorganisasian, hirarki khusus, Kantor/lapangan staf:

\subsection{Budget}

Office(s)/Kantor (-kantor):

Vehicules (transports to the field)/Kendaraan:

Annual budget/Anggaran tahunan:

口 > 1000000000 IRP $\square 1000000000$ to 100000000 IRP $\square 100000000$ to 50000000 IRP $\quad 50000000$ to 10000000 IRP $\square<10000000$ IRP $\square$ No answer

Funds origin

$\square$ Regional $\square$ National $\square$ International $\square$ Private sector $\square$ Public sector (government) $\square$ donations (people) other CSOs

How you look for budget? Who are your major contributors? Do they finance programs or specific activities/projects? Do they ask you for guarantees/special financial or technical reports? Has it changed over time?

Sumber pendanaan (Regional/Indonesia/Internasional dan sektor swasta/sektor publik/donasi). Bagaimana Anda mencari dana? Yang merupakan kontributor utama Anda? Apakah mereka meminta jaminan/laporan keuangan/teknis atau khusus dari Anda? Apakah selama ini ada perubahan?

\section{Activities and strategy/Kegiatan dan strategi:}

\subsection{General presentation}

Short history/presentation of your organization (why? How? What? Evolution? Important dates? Difficulties?). What are your specific missions and mandates? Have they changed over time?

Sejarah singkat organisasi (Mengapa? Bagaimana? Apa? Perkembangan? Tanggal-tanggal penting? Kesulitan-kesulitan?). Apa misi dan mandat utama Anda? Apakah selama ini ada perubahan?

\subsection{Activities}

What kind of activities do you engage in (these 10 last years)? For how long? Where? (projects, duration, location, scale, etc.) Kegiatan seperti apa yang Anda lakukan (selama 10 tahun terakhir). Berapa lama? Di mana? (proyek, durasi, lokasi, skala, dll.)

\subsection{Specific activities/strategies and details}

In Kapuas Hulu, what kind of activities specific to LUP and NRM have you been engaged in? Please provide examples. For how long have you conducted these activities? What have been the objectives of these activities? What strategies have you used to accomplish these activities? How? For how long? In your opinion, what are the most important? Do your activities and/or strategies have changed over time? Why? How?

( local awareness campaign? Media campaign? Counter-mapping? Strikes? Petitions? Lobbying? Negociations? Various projects?).

Di Kapuas Hulu, kegiatan spesifik terhadap Perencanaan Penggunaan Lahan dan Pengelolaan Sumber Daya ALam apa yang Anda lakukan? Tolong memberikan contoh. Untuk berapa lama Anda melakukan kegiatan ini? apa yang menjadi tujuan dari kegiatan ini? Strategi apa yang telah Anda gunakan untuk menyelesaikan kegiatan ini? Apakah Bagaimana? Berapa lama? Menurut Anda, apa yang paling penting? Apakah selama ini ada perubahan? Apakah aktivitas atau/dan strategi anda telah berubah seiring waktu? Mengapa? Bagaimana?

(kampanye penyadaran tingkat lokal? Kampanye media? Pemetaan Tandingan (Communitas peta)? Pemogokan? Petisi? Lobi? Negosiasi? Berbagai proyek?).

\subsection{Projects and areas preferences}

What are the drivers which make you working in these area? What makes you prefer some kind of projects (which ones)? Apa yang mendorong Anda bekerja di lokasi-lokasi tersebut? Apa yang membuat Anda lebih suka (memilih) proyek-proyek tertentu (yang mana)? 


\subsection{Constraints and solutions}

What constraints do you experience during project implementation? How do you overcome these constraints? Apa kendala yang Anda alami selama pelaksanaan proyek? Bagaimana Anda mengatasi kendala?

\subsection{Successful projects}

What past or present project or realization are you very proud of in Kapuas Hulu? Why? Please provide examples. What made these projects successful?

Di Kapuas Hulu, Proyek/Realisasi masa lalu atau sekarang apa yang membanggakan Anda? Mengapa? Tolong, memberikan contoh. Apa yang membuat proyek ini sukses?

\subsection{Projects which partially failed}

What other projects would work better/ has partially failed? Why? How? Please provide examples. How could the failures have been improved?

Proyek lain apa yang bisa lebih berhasil/yang tidak terlalu berhasil? Mengapa? Bagaimana? Tolong, memberikan contoh. Bagaimana mungkin kegagalan telah diperbaiki?

\subsection{Discussion}

Discussion... Besides the projects, what other activities related to land-use planning do you conduct?

Diskusi... Selain proyek, apa kegiatan lain yang berkaitan dengan perencanaan penggunaan lahan Anda melakukan?

\section{Collaboration/relation with other actors/Kolaborasi/Hubungan dengan aktor lain}

\subsection{Collaborations with CSOs/NGOs}

In your LUP/NRM work, do you join forces with other CSOs/NGOs? Which ones? How are joint actions/initiatives organized or are they improvised/informal (or both)? Please provide examples of when you have worked with other CSOs/NGOs (formal and informal partnerships). Please mention the issues that prompted joint action and your assessment of whether the joint action was successful (or not), of factors that influenced success (or failure) and/or ways in which the joint action could be improved. Please indicate what determined your choice of the CSO/NGO you joined forces with. Are you member of national or international networks? Do you get money or other benefits from these partnerships?

Dalam bekerja anda tentang perencanaan penggunaan lahan/Pengelolaan sumber daya alam, apakah Anda bergabung dengan LSM-LSM lain ? Yang mana? Bagaimana bersama aksi/inisiatif (terorganisi atau tidak)? Tolong, memberikan contoh bila Anda telah bekerja dengan LSM-LSM lain (formal dan informal). Tolong, menyebutkan isu-isu yang mendorong tindakan bersama dan penilaian Anda apakah aksi bersama berhasil (atau tidak), faktor yang mempengaruhi keberhasilan (atau kegagalan) dan/atau bagaimana aksi bersama dapat ditingkatkan. Sebutkan apa yang ditentukan pilihan Anda dari LSMLSM Anda bergabung dengan. Bagaimana (Mitra/organisasi teman/kolega)? Kemitraan formal atau informal? Apakah anda anggota jaringan Nasional atau Internasional? Apakah Anda mendapatkan uang atau dari kemitraan ini?

\subsection{Collaborations with authorities}

Do you collaborate and join forces with other actors such local government or other governmental agencies (Forestry, Bapedda, National Parks, etc.)? Which actors? Please provide examples of when you worked with each of the mentioned actors-over what kinds of issues? When? Who initiated contact?

How did you work together-for example, did you have regular meetings, did you conduct joint implementation, did you share information or other kinds of resources?

How would you evaluate the joint work---successful, reasonably successful, failed? What were some of the factors that influenced whether or not this joint work was successful?

How would you describe your relationship with official actors: confrontational/collaborative? Please describe and provide some examples from your recent interactions. How these relations evolved over time? What factors influence this?

Apakah Anda berkolaborasi dan bekerja sama dengan aktor lokal lain seperti pemerintah daerah atau dinas-dinas pemerintah (Kehutanan, Bapedda, TAMAN Nasional)? Jika ya, aktor-aktor yang mana? Tolong, memberikan contoh ketika Anda bekerja dengan masing-masing disebutkan aktor-atas apa jenis masalah/isu-isu? Kapan? Yang memulai kontak? Bagaimana kalian bekerja bersama-sama? Misalnya, apakah kalian memiliki pertemuan rutin? Apakah kalian dilakukan implementasi bersama? Apakah Anda berbagi informasi atau jenis lain sumber daya? Apakah Anda menantang/ 
berkonfrontasi dengan aktor-aktor resmi? Jika ya, mengapa? Bagaimana perkembangan hubungan ini? Faktor-faktor apa yang mempengaruhi?

Bagaimana Anda mengevaluasi kerja bersama --- berhasil, cukup berhasil, gagal? Apa adalah beberapa faktor yang mempengaruhi apakah atau tidak ini kerja bersama berhasil? Bagaimana Anda menjelaskan hubungan Anda dengan aktor resmi: konfrontatif/kolaboratif? Jelaskan dan memberikan beberapa contoh dari interaksi terakhir Anda. Bagaimana hubungan ini berkembang seiring waktu? Apa faktor yang mempengaruhi ini?

\subsection{Collaboration with the private sector}

Do you have relations with the private sector (logging companies? Oil palm companies? Mining companies? Others?) Please describe and provide examples of instances you have interacted with the private sector. What is your assessment of these interactions? Private sector in general? How? Why? What is your opinion about them?

Apakah Anda memiliki hubungan dengan sektor swasta (perusahaan penebangan, Perusahaan kelapa sawit, Perusahaan tambang? Lain-lain ?). Menjelaskan dan memberikan contoh kasus Anda telah berinteraksi dengan sektor swasta. Apa penilaian Anda terhadap interaksi ini? Sektor swasta secara umum? Bagaimana? Mengapa? Apa pendapat Anda tentang mereka?

\subsection{Collaborations with communities}

In what ways do you interact with communities? Do you have any (or have you had any in the past) specific projects with communities that focus on LUP, land tenure and forest use and management? Please provide examples of the purpose, type and location of these projects.

What is your assessment of these projects? Would you rate them as successful or not? Please explain your answer. How do you usually establish contact with communities-or do they make contact with you first? With whom in the community do you interact? What kinds of problems/challenges do you face in your LUP/tenure work with communities? How have you tried to resolve them? How might interactions with communities be improved? Where? Why? Usually, do they contact you or do you make the first contact? How do you interact with them?

Bagaimana Anda berinteraksi dengan masyarakat? Apakah Anda memiliki (atau kau punya di masa lalu) khusus proyek dengan masyarakat yang berfokus pada Perencanaan penggunaan lahan, penguasaan lahan dan manajement dan penggunaan hutan? Memberikan contoh dari jenis, tujuan dan lokasi proyek ini.

Apa penilaian Anda terhadap proyek-proyek ini? Anda menilai mereka sebagai berhasil atau tidak? Tolong jelaskan jawaban Anda?

Bagaimana Anda biasanya menjalin kontak dengan masyarakat-atau mereka melakukan kontak dengan Anda pertama kali? Dengan siapa dalam masyarakat yang Anda berinteraksi? Apa jenis masalah/tantangan yang Anda hadapi dalam Lup/masa kerja Anda dengan masyarakat? Bagaimana Anda mencoba untuk mengatasinya? Bagaimana interaksi dengan masyarakat dapat ditingkatkan? Dimana? Mengapa? Biasanya, mereka menghubungi Anda atau Anda membuat kontak pertama? Bagaimana Anda berinteraksi dengan mereka?

\section{Official Spatial Planning process and laws/Proses dan undang-undang Penataan Ruang resmi 4.1 The Spatial Planning process of Kapuas Hulu Regency}

Have you heard about the Spatial planning process (RTRWK) in Kapuas Hulu? What is the aim? Apakah Anda mengetahui tentang proses penataan ruang (RTRWK) di Kapuas Hulu? Apa tujuannya?

\subsection{Participation to the process}

Have you participated to the recent spatial planning process (RTRWK) conducted by Bapedda?

If yes, in what way did you participate? Please describe-be sure to mention when you participated, what your participation entailed, whether you were formally invited, the issues discussed/covered etc, whether you are/were satisfied with your participation (and why) and what aspects of your participation (and of the land-use planning process) could have been improved in order for you to be effective. Please feel free to share any documentation you may have eg number and content of meetings, minutes of meetings etc.

If you did not participate, please indicate why not. How (meetings, data providing, etc.)? What do you know about it? According to you, how was the participation level of the civil society?

Apakah Anda terlibat dalam proses penataan ruang yang (saat ini) dilakukan Bapedda?

Jika ya, dengan cara apa kau berpartisipasi? Jelaskan-pastikan untuk menyebutkan ketika Anda berpartisipasi, apa partisipasi Anda emban, apakah Anda secara resmi diundang, isu yang didiskusikan/dibahas dll, apakah Anda/puas 
dengan partisipasi Anda (dan mengapa) dan apa aspek partisipasi Anda (dan dari proses perencanaan penggunaan lahan) seharusnya dapat diperbaiki agar Anda menjadi efektif. Silahkan berbagi dokumentasi Anda mungkin memiliki nomor misalnya dan isi rapat, risalah rapat dll.

Jika Anda tidak berpartisipasi, harap menunjukkan mengapa tidak. Bagaimana (pertemuan, data memberikan, dll)? Apa yang Anda tahu tentang hal itu? Menurut Anda, bagaimana tingkat partisipasi masyarakat sipil?

\subsection{Outcomes of the CSO participation}

Do you think that your participation has influenced the process/outcomes? Has it changed the situation in the ground? Please provide concrete examples.

Do you trust this process and people in charge of it? Please explain and also provide examples. How it would be better? Apakah menurut Anda bahwa partisipasi anda telah mempengaruhi hasil? Apakah itu mengubah situasi di tanah? Harap memberikan contoh-contoh konkret.

Apakah Anda percaya proses ini dan orang-orang yang diserahi tanggung jawab untuk itu? Tolong jelaskan dan juga memberikan contoh. Bagaimana caranya agar proses tersebut menjadi lebih baik?

\subsection{Rules and comments on the rules}

Were you been officially invited to the planning process? How many times? When? Have you been informed of the rules? Do you think they have been respected? Were you satisfied with these rules? Why? Please provide examples. Apakah Anda secara resmi diundang untuk proses perencanaan? Berapa kali? Kapan? Apakah Anda pernah diberitahu tentang aturan? Apakah Anda berpikir mereka telah dihormati? Apakah anda puas dengan aturan ini? Mengapa? Harap memberikan contoh.

\subsection{Important issues and priorities for the CSO}

Do you think that some issues have not been discussed but would be important? Why? What kinds of issues should be discussed but have not been discussed? What are some of the contentious/conflictive issues raised or discussed? What did you expect from this new spatial plan? According to you, what should be the priority?

Apa saja isu-isu utama yang dibahas di sana yang menjadi kepedulian Anda? Apakah menurut Anda ada isu-isu yang belum dibahas namun sebenarnya penting? Mengapa? Apa jenis masalah harus didiskusikan tapi belum dibahas? Apa adalah beberapa isu-isu/konflik mengangkat atau dibahas?

Apa yang Anda harapkan dari rencana tata ruang yang baru ini? Menurut Anda, apa yang perlu menjadi prioritas?

\subsection{Other actors involved}

Which other actors have been involved in this process (other CSOs/private sector/institutions)? How? Is there any specific aspect of their participation that you were happy or unhappy with? During the process, did you agree with the other CSOs/NGOs? On what yes and on what no? What where your main differences?

Aktor mana lainnya yang terlibat dalam proses ini (CSO lain/sektor swasta/lembaga)? Bagaimana? Apakah ada aspek tertentu dari partisipasi mereka bahwa Anda senang atau tidak senang dengan? Selama proses tersebut, apakah Anda setuju dengan CSO lain/LSM? Pada apa ya dan pada apa yang tidak? Apa di mana perbedaan utama Anda?

\subsection{Powerful actors and their influence on the process}

Who were the more influential actors in the land-use planning process? Why do you think they were more influential? Please provide examples of instances where they exerted their influence/their influence was apparent. Who was least influential? Why do you think so?

Siapakah aktor yang lebih berpengaruh dalam proses perencanaan penggunaan lahan? Menurut Anda, mengapa mereka lebih berpengaruh? Harap memberikan contoh kasus di mana mereka memberikan pengaruh yang mereka/pengaruh mereka apparent.who adalah paling berpengaruh? Mengapa Anda pikir begitu?

\subsection{Cooperation with other actors}

Were you working/negotiating alone or did you have allies? Did you have preparation meetings with them to define a strategy? Please describe. Do you think this strategy worked or not? What were some of the factors that influenced whether or not you were successful? Did you always agree on strategy? What were some of the points of disagreement? How did you resolve them? 
Apakah saat itu Anda bekerja/bernegosiasi sendirian atau Anda memiliki sekutu? Apakah Anda melakukan pertemuan persiapan dengan sekutu ini untuk merancang sebuah strategi? Jelaskan.

Apakah Anda berpikir strategi ini berhasil atau tidak? Apa adalah beberapa faktor yang mempengaruhi apakah Anda berhasil? Apakah Anda selalu setuju pada strategi? Apa adalah beberapa hal yang berbeda? Bagaimana Anda mengatasinya?

\subsection{General opinion on laws and regulations}

What other comments do you want to make on laws/regulations/administrative issues related to LUP/NRM/ conservation?

Komentar lain apa yang Anda ingin sampaikan untuk UU/regulasi/isu-isu administratif yang terkait dengan Perencanaan Penggunaan Lahan/Pengelolaan Sumber Daya Alam/konservasi?

\section{Others}

Can you quote 3 other CSOs which try to play a role in LUP/tenure in Kapuas Hulu?

Dapatkah Anda menyebutkan 3 LSM lain yang berupaya memainkan peran dalam Perencanaan Penggunaan Lahan di Kapuas Hulu? 


\title{
Appendix 4. Interview guide for government institutions.
}

\section{Government Interview guide}

\author{
Date/Tanggal:
}

Location/Lokasi:

Language/Bahasa:

Audio recording/Rekaman suara:

\section{Basic information/Informasi Pokok}

\section{Name of the institution/Nama lembaga:}

Name(s) of the respondent(s)/Nama(-nama) responden:

Position/function/Fungsi/posisi:

Level of education: $\square$ Doctor (Phd), $\square$ Master degree, $\square$ undergraduate, $\square$ Ujian nasional, $\square$ secondary school, $\square$ primary school

Tingkat pendidikan: $\square$ Doktor (Phd), $\square$ Master, $\square$ S1, $\square$ Ujian nasional, $\square S M A, \square S D / S M P$

Location of the institution/Lokasi lembaga:

Contacts/Kontak:

Domains of activity: $\square$ Environment/ $\square$ Conservation/ $\square$ Agriculture/ $\square$ Indigenous communities/ $\square$ Social issues/ $\square$ Land-use planning/ $\square$ Forest Management/ $\square$ Natural Resources Management/ $\square$ Infrastructures/other

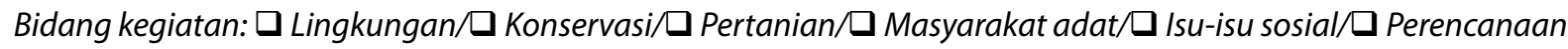

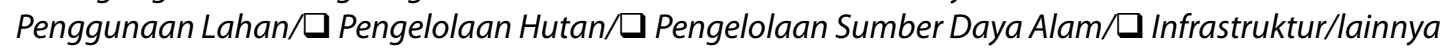

Scale of action of the institution: $\square$ Province $\square$ Regency $\square$ District $\square$ other

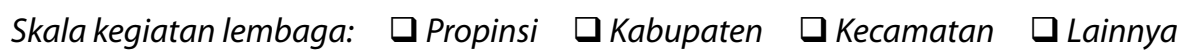

\section{Institution Activity/Kegiatan Lembaga:}

\subsection{Institution activity/mandate}

What is the primary purpose of your institution/entity/office? In particular, what are your aims in terms of forest/land tenure and land-use planning?

Apa tujuan utama lembaga/entitas/kantor Anda? Khususnya, apa sasaran Anda dalam hal penguasaan lahan/hutan dan perencanaan penggunaan lahan?

\subsection{Trends and challenges in Kapuas Hulu}

According to you, what are the trends, the main issues related to NRM and LUP in Kapuas Hulu? What are the challenges you face in relation to Land-use planning and Natural Resources Management in Kapuas Hulu? Please mention how you have addressed these challenges.

Menurut Anda, apa saja tantangan yang Anda hadapi dalam kaitannya dengan Perencanaan Penggunaan Lahan dan Pengelolaan Sumber Daya Alam di Kapuas Hulu?

\section{Collaboration with CSOs/ Kolaborasi dengan Organisasi Masyarakat Sipil (CSO)}

\subsection{Collaboration with CSOs/NGOs}

Does your institution collaborate/interact with NGOs and other CSOs in Kapuas Hulu? Which ones? If yes, please provide examples of how you work together eg how often, when, over what specific issues. What was the role of the CSO/NGO? What was your role? How would you assess your interaction with CSOs/NGOs? What aspects were you happy with? What aspects were you unhappy with? How can/could these be improved? If you do not have collaborated with CSOs/ NGOs, what might be the reasons for not collaborating with them? Do you think you should do in the future? Why? Apakah lembaga Anda bekerja sama/berinteraksi dengan NGO dan CSO lain di Kapuas Hulu? Yang mana? Jika ya, silakan berikan contoh bagaimana Anda bekerja bersama seberapa sering, kapan, atas apa isu-isu spesifik. Apa peran CSO/LSM? Apa peran Anda? Bagaimana Anda menilai interaksi Anda dengan CSO/LSM? Aspek apa yang Anda senang dengan? Aspek apa kau tidak senang dengan? Bagaimana/bisa ini diperbaiki? Jika Anda tidak telah bekerjasama dengan OMS/LSM, apa 
yang mungkin menjadi alasan untuk tidak bekerja sama dengan mereka? Apakah Anda pikir Anda harus melakukan di masa depan? Mengapa?

\section{Opinion about CSOs/NGOs}

In general what do you think about CSOs and NGOs which work on LUP/NRM/environment? Do you think they have an important role in LUP and NRM issues? Do they make a good job? Do they interfere with or disrupt your work? Please provide examples when CSOs/NGOs have disrupted or interfered with your work. How did you deal with this? On the other hand, have you worked well with any CSO/NGO in LUP and NRM issues? Which ones? Please provide examples. Why were you particularly happy about working with these CSOs/NGOs?

Secara umum, apa pendapat Anda tentang CSO dan NGO yang bekerja di bidang Perencanaan Penggunaan Lahan/ Pengelolaan Sumber Daya Alam/lingkungan? Apakah menurut Anda mereka penting? Apakah menurut Anda mereka memiliki peran penting dalam isu-isu Perencanaan Penggunaan Lahan dan Pengelolaan Sumber Daya Alam? Apakah mereka melakukan kerja yang baik?

\section{Spatial Planning Process RTRW-K \\ RTRW-K Kapuas Hulu process}

Have you (your organization) participated in the spatial planning process? How? How often? What have you made exactly? Were/are some NGOs or CSOs involved in the process? Which ones? How? What did you think about their participation? Did they contribute positively to the planning process? If yes, what aspects of their contribution did you find useful? If not, what aspect of their contribution did you not like? Please provide examples.

Sudahkah Anda (organisasi Anda) berpartisipasi terhadap proses perencanaan? Bagaimana? Seberapa sering? Apa yang sudah Anda buat (lakukan) persisnya? Apakah ada NGO atau CSO yang terlibat dalam proses tersebut? Bagaimana keterlibatan mereka? Apa pendapat Anda tentang partisipasi mereka?

\section{Snowball method}

Is there anyone else in your institution who works directly with NGOs and civil society sector? Could you introduce me to her/him? Which other governmental organization works in

Apakah ada orang di lembaga Anda yang bekerja/interaksi dengan NGO dan sektor masyarakat sipil khususnya? Dapatkah saya bicara dengan mereka? 
Appendix 5. List of semi-structured interviews.

\begin{tabular}{|c|c|c|c|c|c|}
\hline Interview & Date & organization & Type & Recorded & Language of interview \\
\hline 1 & $30 / 04 / 2012$ & WWF & NGO & Yes & English \\
\hline 2 & $01 / 05 / 2012$ & AMAN & $\begin{array}{l}\text { Mass-based } \\
\text { organization }\end{array}$ & No & Indonesian+translation \\
\hline 3 & $01 / 05 / 2012$ & AMAN & $\begin{array}{l}\text { Mass-based } \\
\text { organization }\end{array}$ & Yes & Indonesian+translation \\
\hline 4 & $01 / 05 / 2012$ & KABAN & NGO & Yes & Indonesian+translation \\
\hline 5 & $02 / 05 / 2012$ & WALHI & NGO & Yes & Indonesian \\
\hline 6 & 03/05/2012 & PRCF & NGO & Yes & Indonesian+translation \\
\hline 7 & 03/05/2012 & TITIAN & NGO & Yes & Indonesian+translation \\
\hline 8 & 07/05/2012 & DIAN TAMA & NGO & Yes & Indonesian+translation \\
\hline 9 & 08/05/2012 & GEMAWAN & NGO & Yes & Indonesian+translation \\
\hline 10 & 08/05/2012 & RIAK BUMI & NGO & Yes & English \\
\hline 11 & 09/05/2012 & WWF & NGO & Yes & English \\
\hline 12 & $11 / 05 / 2012$ & $\begin{array}{l}\text { Three heads of villages } \\
\text { of Embaloh Hulu district } \\
\text { (Pulau Manakn Benua } \\
\text { Martinus, Benua Ujung) }\end{array}$ & Communities & Yes & Indonesian \\
\hline 13 & $14 / 05 / 2012$ & $\begin{array}{l}\text { BAPPEDA (Regency } \\
\text { development planning } \\
\text { agency) }\end{array}$ & Government & Yes & Indonesian+translation \\
\hline 14 & $14 / 05 / 2012$ & Kaban & NGO & Yes & Indonesian+translation \\
\hline 15 & $14 / 05 / 2012$ & Lanting Bornéo & NGO & Yes & Indonesian+translation \\
\hline 16 & $15 / 05 / 2012$ & Local forestry agency & Government & Yes & Indonesian+translation \\
\hline 17 & $15 / 05 / 2012$ & $\begin{array}{l}\text { BAPPEDA (Regency } \\
\text { development planning } \\
\text { agency) }\end{array}$ & Government & Yes & Indonesian+translation \\
\hline 18 & $15 / 05 / 2012$ & Lanting Borneo & NGO & Yes & Indonesian+translation \\
\hline 19 & $16 / 05 / 2012$ & $\begin{array}{l}\text { BAPPEDA (Regency } \\
\text { development planning } \\
\text { agency) }\end{array}$ & Government & Yes & Indonesian+translation \\
\hline 20 & $16 / 05 / 2012$ & $\mathrm{FFI}$ & NGO & Yes & Indonesian+translation \\
\hline 21 & $22 / 05 / 2012$ & $\mathrm{FFI}$ & NGO & Yes & Indonesian+translation \\
\hline 22 & $23 / 05 / 2012$ & BKNP & Government & Yes & Indonesian+translation \\
\hline 23 & $25 / 05 / 2012$ & $\begin{array}{l}\text { Head of Sungai Utik } \\
\text { village }\end{array}$ & Community & Yes & Indonesian+translation \\
\hline 24 & $29 / 05 / 2012$ & $\begin{array}{l}\text { Customary leader of } \\
\text { Embaloh trib }\end{array}$ & Communities & Yes & Indonesian \\
\hline 25 & $30 / 05 / 2012$ & $\mathrm{GIZ}$ & German cooperation & No & English \\
\hline 26 & $31 / 05 / 2012$ & $\begin{array}{l}\text { BAPPEDA (Regency } \\
\text { development planning } \\
\text { agency) }\end{array}$ & Government & Yes & Indonesian+translation \\
\hline 27 & $01 / 06 / 2012$ & $\begin{array}{l}\text { BPMD (Community } \\
\text { Empowerment and Rural } \\
\text { authorities agency) }\end{array}$ & Government & Yes & Indonesian+translation \\
\hline
\end{tabular}




\begin{tabular}{|c|c|c|c|c|c|}
\hline Interview & Date & organization & Type & Recorded & Language of interview \\
\hline 28 & $01 / 06 / 2012$ & $\begin{array}{l}\text { KESBANGPOL (Political } \\
\text { office of Head of } \\
\text { regency) }\end{array}$ & Government & Yes & Indonesian+translation \\
\hline 29 & 01/06/2012 & $\mathrm{FFI}$ & NGO & Yes & Indonesian+translation \\
\hline 30 & $02 / 06 / 2012$ & Local forestry agency & Government & Yes & Indonesian+translation \\
\hline 31 & 05/06/2012 & $\begin{array}{l}\text { BPMD (Community } \\
\text { Empowerment and Rural } \\
\text { authorities agency) }\end{array}$ & Government & No & Indonesian+translation \\
\hline 32 & 06/06/2012 & $\mathrm{GIZ}$ & German cooperation & Yes & English \\
\hline 33 & 07/06/2012 & WWF & NGO & Yes & English \\
\hline 34 & 07/06/2012 & Plantation agency & Government & Yes & Indonesian+translation \\
\hline 35 & 08/06/2012 & AMAN & $\begin{array}{l}\text { Mass-based } \\
\text { organization }\end{array}$ & Yes & Indonesian+translation \\
\hline 36 & 09/06/2012 & $\begin{array}{l}\text { Head of Sungai Utik } \\
\text { village }\end{array}$ & Communities & Yes & Indonesian+translation \\
\hline 37 & $10 / 06 / 2012$ & AMAN & $\begin{array}{l}\text { Mass-based } \\
\text { organization }\end{array}$ & Yes & Indonesian+translation \\
\hline 38 & $11 / 06 / 2012$ & AMAN & $\begin{array}{l}\text { Mass-based } \\
\text { organization }\end{array}$ & Yes & Indonesian+translation \\
\hline 39 & $13 / 06 / 2012$ & Dinas Lingkungan Hidup & Government & Yes & Indonesian+translation \\
\hline 40 & $13 / 06 / 2012$ & Dinas Pariwisata & Government & Yes & English \\
\hline 41 & $14 / 06 / 2012$ & $\begin{array}{l}\text { BAPPEDA (Regency } \\
\text { development planning } \\
\text { agency) }\end{array}$ & Government & Yes & Indonesian+translation \\
\hline 42 & $15 / 06 / 2012$ & $\begin{array}{l}\text { BAPPEDA (Regency } \\
\text { development planning } \\
\text { agency) }\end{array}$ & Government & Yes & Indonesian+translation \\
\hline 43 & $15 / 06 / 2012$ & $\begin{array}{l}\text { BAPPEDA (Regency } \\
\text { development planning } \\
\text { agency) }\end{array}$ & Government & Yes & Indonesian+translation \\
\hline 44 & $18 / 06 / 2012$ & LBBT & NGO & Yes & Indonesian+translation \\
\hline 45 & $18 / 06 / 2012$ & AMAN & $\begin{array}{l}\text { Mass-based } \\
\text { organization }\end{array}$ & Yes & Indonesian+translation \\
\hline 46 & $19 / 06 / 2012$ & $\begin{array}{l}\text { communities from Kec } \\
\text { Embaloh Hulu }\end{array}$ & & & Indonesian+translation \\
\hline 47 & $19 / 06 / 2012$ & Gemawan & NGO & Yes & Indonesian+translation \\
\hline 48 & $20 / 06 / 2012$ & Riak Bumi & NGO & Yes & English \\
\hline 49 & $21 / 06 / 2012$ & PPSHK & NGO & Yes & Indonesian+translation \\
\hline 50 & $22 / 11 / 1961$ & PPSDAK & NGO & Yes & Indonesian+translation \\
\hline 51 & $26 / 06 / 2012$ & PPSDAK & NGO & Yes & Indonesian+translation \\
\hline 52 & $26 / 06 / 2012$ & LBBT & NGO & Yes & Indonesian+translation \\
\hline 53 & $27 / 06 / 2012$ & $\mathrm{FFI}$ & NGO & No & Indonesian \\
\hline 54 & $28 / 06 / 2012$ & Lanting Borneo & NGO & Yes & Indonesian \\
\hline 55 & $29 / 06 / 2012$ & JKPP & NGO & Yes & Indonesian \\
\hline 56 & $29 / 06 / 2012$ & Sawit Watch & NGO & Yes & Indonesian \\
\hline
\end{tabular}


Appendix 5. Continue

\begin{tabular}{clllcl}
\hline Interview & Date & organization & Type & Recorded & Language of interview \\
\hline 57 & $04 / 07 / 2012$ & LEI & NGO & Yes & Indonesian \\
58 & $04 / 07 / 2012$ & FWI & NGO & No & Indonesian \\
59 & $11 / 07 / 2012$ & FFI & NGO & No & Indonesian \\
60 & $12 / 07 / 2012$ & CIFOR & Research & No & English \\
61 & $13 / 07 / 2012$ & CIFOR & Research & No & English \\
62 & $13 / 07 / 2012$ & WWF & NGO & No & Indonesian \\
63 & $14 / 07 / 2012$ & Greenpeace & NGO & Yes & Indonesian \\
64 & $14 / 07 / 2012$ & WWF & NGO & No & English \\
\hline
\end{tabular}




\section{Appendix 6. Active logging concessions in Kapuas Hulu in 2012}

\begin{tabular}{|c|c|c|c|c|}
\hline Name of the company & $\begin{array}{l}\text { Date of issuance } \\
\text { of the permit }\end{array}$ & $\begin{array}{l}\text { Duration of } \\
\text { the permit } \\
\text { (in years) }\end{array}$ & $\begin{array}{l}\text { Area } \\
\text { (in ha) }\end{array}$ & Location (district) \\
\hline PT. Bakti Dwipa Kariza & 2006 & 20 & 11010 & Silat Hulu \\
\hline PT. Karyarekanan Bina-Bersama & 2004 & 45 & 43810 & Silat \\
\hline PT. Toras Banua Sukses & 2006 & 20 & 24920 & Mandalam, Sibau and Kapuas \\
\hline PT. Kawedar Wood Industry & 2009 & 35 & 69050 & Mandai \\
\hline TOTAL & & & 148790 & \\
\hline
\end{tabular}

Source: Forestry Agency (2012) 
Appendix 7. CSOs involved in Kapuas Hulu and important dates

\begin{tabular}{lllccc}
\hline Name & Type of CSO & Scope & Foundation & $\begin{array}{c}\text { First activity in } \\
\text { Kapuas Hulu }\end{array}$ & $\begin{array}{c}\text { Last activity in } \\
\text { Kapuas Hulu }\end{array}$ \\
\hline Riak Bumi & NGO & local & 2000 & 2000 & 2012 \\
SEBATOPA & NGO & local & 2011 & 2011 & 2012 \\
Kaban & NGO & regional & 2009 & 2009 & 2012 \\
Titian & NGO & regional & 1995 & 2005 & 2012 \\
Dian Tama & NGO & regional & 1987 & 1996 & 2009 \\
Lanting Borneo & NGO & regional & 2008 & 2009 & 2012 \\
LBBT & NGO & regional & 1993 & 1996 & 2012 \\
PPSDAK & NGO & regional & 1994 & 1998 & 2012 \\
PPSHK & NGO & regional & 1995 & 1998 & 2009 \\
WALHI & NGO & national & 1990 & 2000 & 2011 \\
AMAN & Mass-based organization & national & 1998 & 1998 & 2012 \\
Sawit Watch & NGO & national & 1998 & 2002 & 2011 \\
FWI & NGO & national & 1997 & 2007 & 2007 \\
LEI & NGO & national & 1999 & 2004 & 2008 \\
JKPP & NGO & national & 1996 & 2011 & 2012 \\
WWF & NGO & international & 1998 & 1995 & 2012 \\
FFI & NGO & international & 1903 & 2008 & 2012 \\
GreenPeace & NGO & international & 1971 & 2006 & 2009 \\
Wetlands International & NGO & international & 1937 & 1992 & 1997 \\
PRCF-Indonesia & NGO & international & 2000 & 2004 & 2012 \\
WRI (+SEKALA) & Research center & international & 1982 & 2009 & 2010 \\
CIFOR & Research center & international & 1993 & 2000 & 2012 \\
TROPENBOS & Research center & international & $?$ & 2005 & 2007 \\
\hline & & & & \\
\hline
\end{tabular}




\section{Appendix 8. Examples of projects and activities in Kapuas Hulu for 23 CSOs}

\begin{tabular}{|c|c|c|c|c|}
\hline Name & Scope & Type of CSO & $\begin{array}{l}\text { First activity in } \\
\text { Kapuas Hulu }\end{array}$ & Examples of activity \\
\hline Riak Bumi & local & NGO & 2000 & $\begin{array}{l}\text { Training and facilitation for honey harvesting and } \\
\text { marketing in DSNP, training communities of DSNP in } \\
\text { ecotourism, micro-hydro project, multistakeholder } \\
\text { meetings for reducing conflicts on natural resources } \\
\text { management, community mapping in DSNP, coalition } \\
\text { to save Danau Sentarum }\end{array}$ \\
\hline SEBATOPA & local & NGO & 2011 & $\begin{array}{l}\text { Public protest against BKNP, support of Embaloh Hulu } \\
\text { communities agains oil palm concession }\end{array}$ \\
\hline Kaban & regional & NGO & 2009 & $\begin{array}{l}\text { Socioeconomic identification in } 22 \text { villages around } \\
\text { Danau Siawan-socialization about REDD and climate } \\
\text { change (FFi project), assessment, information for } \\
\text { hutan desa in } 23 \text { villages (FFI project), participative } \\
\text { mapping in eight villages around Danau Siawan (FFI } \\
\text { REDD project), hutan desa facilitation in five villages } \\
\text { (FFI project) }\end{array}$ \\
\hline Titian & regional & NGO & 2005 & $\begin{array}{l}\text { Illegal logging monitoring for law enforcement } \\
\text { with KAIL (coalition anti-illegal logging), Monitoring } \\
\text { illegal wildlife trade from DSNP, Community rangers } \\
\text { patrolling for Orangutan conservation in DSNP } \\
\text { (FFI project) }\end{array}$ \\
\hline Dian Tama & regional & NGO & 1996 & $\begin{array}{l}\text { Training communities for harvesting and marketing } \\
\text { NWFP in DSNP, forest fire mapping and social } \\
\text { assessment in DSNP (CIFOR project), burned land } \\
\text { rehabilitation and community groups for fire } \\
\text { extinction (WWF project) }\end{array}$ \\
\hline $\begin{array}{l}\text { Lanting } \\
\text { Borneo }\end{array}$ & regional & NGO & 2009 & $\begin{array}{l}\text { Community mapping assessment in } 10 \text { villages, hutan } \\
\text { desa assessment (FFI project), participative mapping } \\
\text { in five villages (FFI project), BRWA mechanism in } \\
\text { Kapuas Hulu }\end{array}$ \\
\hline LBBT & regional & NGO & 1996 & $\begin{array}{l}\text { Communities enforcement with Dayak Iban } \\
\text { communities in Sungai Utik (seven villages), } \\
\text { Mandalam communities, kalis communities, } \\
\text { workshops on communities rights in Putussibau }\end{array}$ \\
\hline PPSDAK & regional & NGO & 1998 & $\begin{array}{l}\text { Community mapping in } 35 \text { villages ( } 500,000 \text { to } \\
550,000 \text { ha), seminar about limits, borders between } \\
\text { sub-villages, villages, districts, large-scale community } \\
\text { mapping (JKPP-Lanting Borneo project) }\end{array}$ \\
\hline PPSHK & regional & NGO & 1998 & $\begin{array}{l}\text { Research, training, alternative incomes, people } \\
\text { empowerment, meetings facilitation and } \\
\text { documentation in Sungai Utik and six other villages }\end{array}$ \\
\hline WALHI & national & NGO & 2000 & $\begin{array}{l}\text { Media campaign against oil palm expansion, advocacy } \\
\text { of various land-conflict cases, action against SinarMas } \\
\text { group in Suhait, Coalition RTRW-P West Kalimantan }\end{array}$ \\
\hline AMAN & national & $\begin{array}{l}\text { Mass-based } \\
\text { organization }\end{array}$ & 1998 & $\begin{array}{l}\text { Communities enforcement with } 17 \text { Dakak } \\
\text { communities and tribes, land-conflict cases advocacy } \\
\text { in Mandalam, Sungai Utik and Punan, BRWA } \\
\text { mechanism in West Kalimantan }\end{array}$ \\
\hline Sawit Watch & national & NGO & 2002 & $\begin{array}{l}\text { Investigations on illegal logging in the borderland } \\
\text { with Malaysia, lobbying and international campaign } \\
\text { against the transboundary oil palm mega project, } \\
\text { revitalization of indigenous institutions, coalition to } \\
\text { save the Earth of Borneo }\end{array}$ \\
\hline
\end{tabular}


Appendix 8. Continued

\begin{tabular}{|c|c|c|c|c|}
\hline Name & Scope & Type of CSO & $\begin{array}{l}\text { First activity in } \\
\text { Kapuas Hulu }\end{array}$ & Examples of activity \\
\hline FWI & national & NGO & 2007 & Spatial data analysis in Sungai Utik for LEl certification \\
\hline LEI & national & NGO & 2004 & Certification of Sungai Utik village customary forest \\
\hline JKPP & national & NGO & 2011 & $\begin{array}{l}\text { 3D participative mapping in Sungai Utik village, large- } \\
\text { scale community mapping in Embaloh Hulu district } \\
\text { (with Lanting Borneo and PPSDAK) }\end{array}$ \\
\hline WWF & international & NGO & 1995 & $\begin{array}{l}\text { Surveys and writting management plan of BKNP, } \\
\text { implementation of BKNP management plan and } \\
\text { socialization with communities, various conservation } \\
\text { activities in DSNP, ecological corridor project between } \\
\text { BKNP and DSNP, Payment for Environmental Services } \\
\text { project in Mandal, Participation in RTRW-K revision } \\
\text { process, writing the management plan of ecological } \\
\text { corridor strategic area, technical working group of the } \\
\text { Earth of Borneo Initiative }\end{array}$ \\
\hline $\mathrm{FFI}$ & international & $\mathrm{NGO}$ & 2008 & $\begin{array}{l}\text { HCVF assessment in two oil palm concessions, REDD+ } \\
\text { ecosystem restauration project in Danau Siawan, } \\
\text { village forest facilitation project, HCVF landscape } \\
\text { assessment project, forest rangers facilitation in } \\
\text { DSNP, participative zonation in DSNP, RTRW-K revision } \\
\text { process participation }\end{array}$ \\
\hline Greenpeace & international & NGO & 2006 & $\begin{array}{l}\text { Action against SinarMas group in Suhait, international } \\
\text { campaign against SinarMas group using examples } \\
\text { from Kapuas Hulu }\end{array}$ \\
\hline $\begin{array}{l}\text { Wetlands } \\
\text { International }\end{array}$ & international & $\mathrm{NGO}$ & 1992 & $\begin{array}{l}\text { Biodiversity conservation in Danau Sentarum area, } \\
\text { collaborative management initiative for DSNP }\end{array}$ \\
\hline $\begin{array}{l}\text { PRCF- } \\
\text { Indonesia }\end{array}$ & international & NGO & 2004 & $\begin{array}{l}\text { Monitoring of crocodile population in DSNP, } \\
\text { hutan desa facilitation in four villages (FFI project), } \\
\text { facilitation of participative conservation planning in a } \\
\text { few villages (WWF project) }\end{array}$ \\
\hline $\begin{array}{l}\text { WRI } \\
(+ \text { SEKALA) }\end{array}$ & international & $\begin{array}{l}\text { Research } \\
\text { center }\end{array}$ & 2009 & $\begin{array}{l}\text { POTICO project for sustainable oil palm plantations, } \\
\text { community mapping, RTRW-K revision process } \\
\text { participation }\end{array}$ \\
\hline CIFOR & international & $\begin{array}{l}\text { Research } \\
\text { center }\end{array}$ & 2000 & $\begin{array}{l}\text { Research into forest fires, oil palm sector on DSNP, } \\
\text { collaborative management in DSNP, CoLUPSIA project }\end{array}$ \\
\hline TROPENBOS & international & $\begin{array}{l}\text { Research } \\
\text { center }\end{array}$ & 2005 & $\begin{array}{l}\text { Spatial zonation of DSNP area, multi-stakeholder } \\
\text { management of DSNP }\end{array}$ \\
\hline
\end{tabular}




\section{Appendix 9. List of international donors quoted by the interviewed CSOs}

List of international donors quoted by the interviewed CSOs

USAID, Monahan family in UK, Asia Foundation, ARCUS Foundation, Global Witness, CORDAID (NTFP program), CIFOR, European Union, ICCA Japan, WWF (umbrella org), Wetlands International, CRS Jakarta, Ford Foundation, ASOKA foundation, ASPPUK, RNIP Netherland, PRCF Internation, National Geographic, EU-FLEGT, FHNI, NTFP exchange program, DFID-UK, IUCN Netherland, ITTO, ECCO, FFI, Ford Foundation, The Samdana Institut, Partner Safe, Mercury Bank, PAKAD foundation, GIZ, RDR Germany, Oxfam-Novib, SSNC: Swedish Society Nature Conservation, Miserior Germany, Triple 11 Belgium, DSP-Kemala, ILC (International Land Coalition), ICCO (Netherland) 

CIFOR Working Papers contain preliminary or advance research results on tropical forest issues that need to be published in a timely manner to inform and promote discussion. This content has been internally reviewed but has not undergone external peer review.

In Indonesia, logging and oil palm concessions attributed by the government have caused high rates of deforestation and forest degradation. Community land rights have been generally ignored, on the pretext of development needs and general interest. In reaction, a growing number of civil society organizations (CSOs) have addressed these environmental and social issues at the national level. With the introduction of the decentralization process following the fall of the dictator Suharto in 1998, land-use planning became relevant at the province and regency levels. The Kapuas Hulu regency in West Kalimantan revised its land-use plan in 2010. A variety of CSOs have tried to influence land-use planning (LUP) processes and community land-rights issues in Kapuas Hulu. Few international conservation NGOs have used soft lobbying approaches with the Kapuas Hulu Government. They contribute to the policy decision-making process and to field project implementation. At the same time, at the province scale, a large Indonesian CSO coalition challenged the government and criticized the lack of civil society participation and community land-rights recognition during the LUP process. Thus, CSOs play various roles in LUP and community-rights issues using different strategic approaches at different scales.

This research was carried out as part of the European Union funded Collaborative Land Use Planning and Sustainable Institutional Arrangement project (CoLUPSIA). Run by CIRAD in partnership with CIFOR, TELAPAK and several local NGOs and Universities, the project aims to contribute to avoided environmental degradation and to strengthen land tenure and community right by collaboratively integrating all stakeholders' views in land use planning processes. The outputs revolve around the relationship between land use planning, land allocation and the provision and potential payment of ecosystem services. The project focuses on two regencies (kabupaten), Kapuas Hulu and Central Maluku in Indonesia.
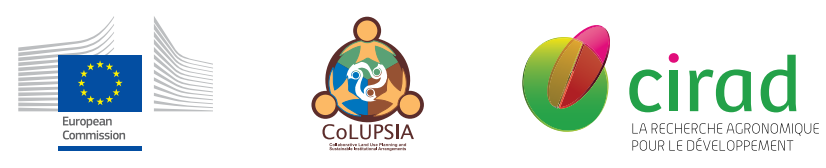